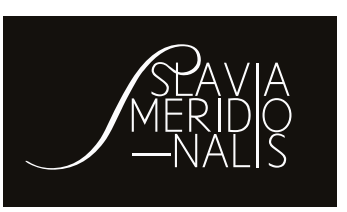

Citation:

Article No.: 1919

Cetnarowicz, A., Popek, K. (2019). The last twenty-five years of Polish humanities related to the history of the nations and countries of former Yugoslavia, their political and cultural relations with Poles, and unionism ideas in the second half of the 19th century. Slavia Meridionalis, 19. https://doi.org/10.11649/sm.1919

\title{
Antoni Cetnarowicz
}

Jagiellonian University

https://orcid.org/0000-0001-5309-7609

\section{Krzysztof Popek}

Jagiellonian University

https://orcid.org/0000-0001-5864-5264

\section{The Last Twenty-Five Years of Polish Humanities Related to the History of the Nations and Countries of Former Yugoslavia, their Political and Cultural Relations with Poles, and Unionism Ideas in the Second Half of the $19^{\text {th }}$ Century ${ }^{1}$}

\section{Introduction}

Studies on the history of Slavdom, which go back to the turn of the $18^{\text {th }}$ and $19^{\text {th }} \mathrm{c}$., already have a long-established tradition in Poland. The development of Slavonic studies in the $19^{\text {th }} \mathrm{c}$. was strictly related to the development of Slavic studies, which at the time meant Slavic philology, i.e. the study of Slavic lan-

1 This paper is part of an OPUS 13 project, funded by the National Science Centre in Kraków, called "Between two congresses in Prague: relations among the Slavs in Central and South-East Europe in 1848-1908” (2017/25/B/HS3/00240).

This work was supported by a grant from National Science Centre in Poland, called "Between two congresses in Prague: relations among the Slavs in Central and South-East Europe in 1848-1908” (2017/25/B/HS3/00240). Authors' contribution: both authors participated equally in the concept of the study and drafting the manuscript. Competing interests: no competing interests have been declared.

Publisher: Institute of Slavic Studies, Polish Academy of Sciences.

This is an Open Access article distributed under the terms of the Creative Commons Attribution 3.0 PL License (creativecommons.org/licenses/by/3.0/pl/), which permits redistribution, commercial and non-commercial, provided that the article is properly cited. (c) The Author(s) 2019. 
guages and literatures. The first department of Slavic studies was established at Jagiellonian University in 1818 and has just celebrated its 200th anniversary. It was not until the end of the 19th century that historians started paying attention to Slavdom; however, they were more interested in the most ancient history of Slavic peoples. The Slavic Club, established in Kraków in 1901, and the monthly "Świat Słowiański" ["The Slavic World"] it published, played an important role. After Poland regained independence in 1918, Polish historical and Slavic studies made visible progress. Kraków played the leading role as it was there that the Slavic Department was created at Jagiellonian University in 1925. Meanwhile, at King John Casimir University in Lviv the first interdisciplinary studies on the ethnogenesis of Slavs were undertaken as a result of collaboration between the departments of Slavic studies, anthropology and prehistory. However, studies on the early modern history of Slavs were still of a relatively low standard.

After World War II, adopting a Marxist research methodology caused a shift in Polish historiography which left behind political history and embarked on socio-economic studies. Polish Slavic studies were reborn in Kraków, where the Slavic Department was re-established and over a dozen of whose subdepartments were concerned with the most recent history of Slavdom and the history of the Balkans. However, linguistics and studies on the genesis of Slavs continued to lead the way, while modern Slavic problems still sparked little interest among historians. Studies on the history of Western and Southern Slavs were also conducted at Adam Mickiewicz University in Poznań. It was not until the 1980s that significant changes in the field of studies on Slavdom became visible; this was especially true in the case of addressing nationality issues.

After the political transformation in Poland in 1989, Polish Slavic studies continued to grow quite resiliently, although, as Krzysztof Makowski noted, "they are defined in quite a traditional way, i.e. as philological studies" (Makowski, 2013, p. 13). Studies on national stereotypes and national identity, mainly in the Balkans, are conducted at the Institute of Slavic Studies of the Polish Academy of Sciences, as well as at Jagiellonian University, the University of Warsaw, the University of Poznan, and the University of Silesia in Katowice. The Institute for Central and Eastern Europe, established in Lublin in 1991, has also been successfully active in this field.

Over the last twenty-five years, there has been a considerable increase in the number of scholarly institutions and academic journals which study the history of Southern Slavs. In 1991 in Kraków, the Commission for Central 
Europe of the Polish Academy of Arts and Sciences was established and has since published the periodical "Prace Komisji Środkowoeuropejskiej PAU" ["The Works of the Central European Commission of PAAS"], now entitled "Studia Środkowoeuropejskie i Bałkanistyczne" ["Central European and Balkan Studies"]. In Warsaw, the Commission for Slavonic Historical Studies (later renamed the Team for Slavonic and East European Studies) was established at the Polish National Historical Committee of the Polish Academy of Sciences, which has been addressing historical topics more and more frequently. The circle of Slavic studies specialists in Warsaw became more active, and a few years ago the Institute of Western and Southern Slavic Studies of the University of Warsaw established a Team for Studies on Slavic Cultures on the Outskirts of the Habsburg Monarchy. A number of journals are published, including international ones such as "Slavia Meridionalis", published by the Institute of Slavic Studies of the Polish Academy of Sciences, "Pamiętnik Słowiański" ["The Slavic Diary"], under the patronage of the Committee of Slavic Studies of the Polish Academy of Sciences ${ }^{2}$, "Poznańskie Studia Slawistyczne" ["Poznań Slavonic Studies"], published by the Institute of Slavonic Philology of the Adam Mickiewicz University in Poznań, and "Południowosłowiańskie Zeszyty Naukowe" ["The Southern Slavic Scholarly Journal”], published by the Department of Southern Slavic Studies of the University of Łódź. Alongside "Balcanica Posnaniensia", which is published by Adam Mickiewicz University in Poznań, two newer publications are "Studia Danubiana et Balcanica", which is part of the "Scholarly Journals of the Jagiellonian University: History Notebooks", published by Jagiellonian University's Institute of History, and "Studia z Dziejów Rosji i Europy Środkowo-Wschodniej" ["Studies on the History of Russia and East-Central Europe"], under the patronage of the Institute of History of the Polish Academy of Sciences.

We should note with satisfaction the steady yet still limited growth of international collaboration between circles of historians and Slavists (which is reflected, e.g., in the participation of Polish historians in congresses, conferences, and symposia held in Croatia, Serbia, Slovenia, Bosnia and Herzegovina, Montenegro, and Macedonia), as well as the fact that this subject matter was addressed during the meeting of the General Congress of Polish Historians in Kraków (2004) and Olsztyn (2009) and at Congresses of International Researchers of Polish History which take place cyclically in Kraków.

${ }^{2}$ Unfortunately, this important Slavist journal has not been published since 2013. 
This paper presents an overview of the research topics which have appeared in Polish humanities since 1989 concerning the second half of the $19^{\text {th }}$ history of the nations and countries which went on to create the Yugoslavian state after 1918. We chose the period between 1848 and 1908. These two dates are of key importance for the history of Europe as well as Southern Slavs: 1848 is naturally related to the Spring of Nations, while 1908 saw the annexation of Bosnia and Herzegovina by Austria-Hungary.

\section{Slovene studies}

The history of Slovenes, a small Slavic nation at the foot of the Alps on the border between the Germanic/Romance and Slavic worlds, was almost unknown to the general Polish public until recently. It was not until the events related to the collapse of Yugoslavia in the first half of the 1990s and the establishment of independent Slovenia that the Polish public started to pay more attention to the existence and history of their southern brothers. Polish historians have devoted very little attention to 19th-century Slovene history - a time that was decisive for the shaping of this nation. Polish readers can find basic information and brief descriptions of events prior to the early 1990s only in larger syntheses about the history of Southern Slavic nations and Austria (Batowski, 1938; Wereszycki, 2015³; Skowronek, Tanty \& Wasileski, 1985).

A turning point came in 1990, when Jagiellonian University Press published a book entitled Słoweński ruch narodowy i jego stosunek do spraw polskich 1848-1879 [The Slovene National Movement and Its Attitude Towards Polish Affairs 1848-1879], written by Antoni Cetnarowicz (1990a), a Kraków-based historian. A student of professors Henryk Wereszycki and Wacław Felczak, Antoni Cetnarowicz has since conducted systematic studies on the history of Slovenes and political relations between Poland and Slovenia in the $19^{\text {th }} \mathrm{C}$. and has published his findings in monographs, journals, and various Polish and foreign collective publications. The monograph mentioned above was an attempt to present the development of the Slovene national movement during its most important period, as well as its attitude towards Poles and Polish affairs. The author selected and expanded on several topics which best

3 This is the third edition of the book from 1975. 
reflected the type of Polish problems which held the interest of Slovenes and made it possible to understand their attitude towards Poles. The monograph used Slovene and some Polish archival materials, as well as various Slovene and Austrian printed sources, in particular contemporary Slovene and to a lesser extent Polish and Austrian press and magazines. The development of the Slovene national movement was presented almost exclusively on the basis of these sources. Among the articles about the political history of Slovenes in the second half of the $19^{\text {th }} \mathrm{c}$., two articles authored by Antoni Cetnarowicz draw our attention: the first discusses Slovene national programs prior to 1914; the second presents the details of the genesis, contents, and history of the first political program of the so-called "United Slovenia" (Cetnarowicz, 1993b, 1993d). In one of the articles published in the post-conference materials after the international conference of Slavists and historians in Kraków in 1995, the same author presented a number of examples from the history of SloveneGerman relations in the $19^{\text {th }}$ c., i.e. within the Habsburg Monarchy, which showed that they were not necessarily characterized by enmity and fierce fighting (Cetnarowicz, 1996b). In 2001, Antoni Cetnarowicz's encyclopedic entry on the entire history of Slovenia was published in Encyklopedia Historyczna Świata [Historical Encyclopaedia of the World] (Cetnarowicz, 2001a).

Although among Polish historians Antoni Cetnarowicz is an exceptional case of a researcher of Slovenes in early modern and contemporary times, the idea of nation, national awareness and identity has been addressed more frequently in the works of Slavists, especially experts on Slovene studies. This is hardly surprising since, as Zdzisław Darasz noted, in the $19^{\text {th }} \mathrm{C}$., during the period when the modern Slovene nation was shaped, "the art of the word was becoming more significant as virtually the most effective weapon in the fight for national subjectivity and identity" (Darasz, 1995).

Damian Kubik, a Kraków-based Slavist, devoted his studies to the shaping of the idea of the Slovene nation. He drew attention to the specific political, social and cultural conditions in which the idea of a nation evolved among Slovenes, emphasizing that it was "the difficult history and complicated relations with their neighbors (...) that strengthened their sense of separateness and the will to cultivate their language and national culture" (Kubik, 2017a).

The achievements and publications of Polish Slovene studies as part of Polish-Slovene relations were shown by Emil Tokarz in an article published by the Slovene Slavist journal "Slavistična revija". He emphasized the fact that Poles were in many cases role models for Slovenes, as illustrated, e.g., by numer- 
ous translations of Polish literary works. The author observed that Poles, on the other hand, were interested in Slovenes' rational behavior with regard to socio-political matters (Tokarz, 1994). The role of symbols in the shaping and establishing of national identity in Slovene politics was presented by Maciej Falski in two articles which were published in "Pamiętnik Słowiański" ["The Diary"] and "Poznańskie Studia Slawistyczne" ["The Poznań Slavic Studies”] (Falski, 2008a, 2017).

Historical topics concerning the issue of Slovene national identity in the $19^{\text {th }} \mathrm{c}$. can be found in several works of Z. Darasz, the Slovene studies specialist mentioned above. The publications of this author, who stresses that he considers himself a Yugoslavian studies specialist, include works in which Slavophile and Yugoslavian elements of Slovene culture are strongly emphasized. After Slovenes rejected Illyrism, according to Darasz the alternative became the cult of Saints Cyril and Methodius. The same author also showed an interesting perspective on Slovene-Polish "cultural mutuality" in an article in "Świat Słowiański" [“The Slavic World”] (Darasz, 1998a, 2004, 2007, 2008, 2017). Władysław Kryzia also presented the shaping of the Slovene national identity in a concise way in his very useful textbook for Slavists, the longest chapter of which is devoted to the Slovene national and linguistic revival. He analyzed the phenomenon of the simultaneous development of linguistic unity, the sense of the Slovene nation, and the movement for a "United Slovenia" (Kryzia, 2008b). The same author wrote a sketch discussing nationality and linguistic problems in the memories of Josip Vošnjak, one of the leaders of the Slovene National Movement in the second half of the $19^{\text {th }} \mathrm{c}$. The author cites a fragment of Vošnjak's recollections about the best-known events and facts related to the national movement and the activity of its leaders in Styria, including the "mass rally" (tabor) in Ljutomer, or the sessions of the Styria State Parliament (Kryzia, 2008a).

As for Polish-Slovene political relations in the second half of the $19^{\text {th }} \mathrm{c}$., the subject matter is discussed extensively and comprehensively by A. Cetnarowicz in the monograph mentioned above, as well as in a number of his works published in Polish, Austrian, Slovene and German journals and collective works. The author also attempted to show these relations comprehensively in a number of sketches published in Polish, Slovene and German, which included not only examples of cooperation and mutual support (especially on the forum of the Viennese Imperial Council), but also criticisms of Polish policies and the nationalist movement in Poland (Cetnarowicz, 2007b, 1996a, 1997a, 2016a, 2016b, ). 
The Slovene attitude towards Polish affairs during the Spring of Nations was the subject of A. Cetnarowicz's presentation during the international symposium in Ljubljana in June 1991 (a mere two days after Slovenia's independence was proclaimed), which was published a year later in Miklošičev zbornik [F. Miklošič’s Anthology] (Cetnarowicz, 1992b). Slovene opinions about the activity of Polish deputies in the Imperial Council during the first two years of the Dual Monarchy and the Slovenes' attitude towards Galician autonomy was presented by A. Cetnarowicz in two articles published in the leading Slovene historical journal, "Zgodovinski časopis" (Cetnarowicz 1992a, 1994).

Meanwhile, the voices and opinions of the Galician press concerning the Slovene national movement in the first years of the Dual Monarchy, when a sort of coalition of Polish, Slovene and Tyrolese deputies was formed in the Imperial Council, were discussed by A. Cetnarowicz in two articles (Cetnarowicz, 1998c, 2001c). The same author presented more detailed Polish opinions and views about Slovenes and other Southern Slavs in materials from an international conference on stereotypes in former Yugoslavia that took place in Tratten/Pošišče in Austria in 1996 (Cetnarowicz, 2002a).

A look at the other side, namely the political life in Galicia from the viewpoint of the Slovene national movement and Slovene opinions about PolishUkrainian and Polish-Russian relations, was included by this author in two other articles (Cetnarowicz, 2011c, 2015a). While Polish policy concerning Ruthenians was consistently criticized by Slovenes, they were very supportive and appreciative of the Polish fight against German pressure in the Prussian partition, as A. Cetnarowicz showed elsewhere (2009a).

\section{Croatian studies}

Polish historical and Slavic studies since the political transformation in 1989 have devoted much more attention to the history of Croats and Polish-Croatian relations in the second half of the $19^{\text {th }}$ century than to Slovenes. However, we should note that this subject matter was not previously obscure. Since 1986, when W. Felczak and T. Wasilewski published Historia Jugosławii [A History of Yugoslavia], Polish readers have had access to a synthesis of the $19^{\text {th }}$-century history of the Croatian land written by W. Felczak - an excellent expert on the history of Croatia in this period (Felczak \& Wasilewski, 1985; Felczak, 1963, 1967, 1968, 1969). 
With regard to general encyclopedic publications, we should mention Leksykon tradycji chorwackich [A Lexicon of Croatian Traditions]; written by Joanna Rapacka, a specialist in Slavic studies, this is a compendium of knowledge about the most important events and figures in the history of Croatia (Rapacka, 1997). We owe a number of monographs and other works on the history of Croatian culture (including some about the period in question) to the great historical intuition and knowledge of this outstanding, prematurely deceased Slavist. Her works include a popular science synthesis of the history of the Republic of Ragusa, a collection of sketches collectively entitled Godzina Herdera [Herder's Hour] about Serbian-Croatian relations and the Yugoslavian idea, as well as her posthumously published last book entitled Śródziemnomorze - Europa - Bałkany [The Mediterranean - Europe - the Balkans], in which she devoted the majority of her attention to describing Croatian culture in the $19^{\text {th }} \mathrm{c}$., including the problems of the birth and transformations of the Croatian national identity (Rapacka, 1995, 2002) ${ }^{4}$. Her two studies on the role of regionalism and on the shaping of national ideologies, as illustrated by Croatia, are very valuable sources of knowledge about Croatian culture (Rapacka, 1993, 1996).

Polish historians have addressed the topic of Croatian history in the second half of the $19^{\text {th }} \mathrm{c}$. in many works, but they have usually focused on PolishCroatian relations or the idea of Pan-Slavism. Relatively few authors have conducted studies strictly concerning the history of Croatia. A few works on the political and social history of Croatians in the second half of the $19^{\text {th }} \mathrm{C}$. were published by Antoni Giza, a Szczecin-based historian, at the beginning of this millennium (Giza, 2001a, 2001c, 2001e, 2002d).

Dariusz Dmowski, who represents the same academic circle, addressed the Croatian national movement in Dalmatia, the Croatian attitude towards the Dual Monarchy, and the development of the Yugoslavian idea in Croatian lands in the early $20^{\text {th }}$ c. (Dmowski, 1992, 1995, 2000)

In an attempt to explain why this country attracted so many Polish wanderers, Katarzyna Wołek (later: Wołek-San Sebastian) devoted an article to the image of Dalmatia in $19^{\text {th }}$-century Polish travel writing (Wołek, 2004).

The history of the national revival in Dalmatia was depicted by Antoni Cetnarowicz in great detail and on the basis of extensive queries in Croatian,

${ }^{4}$ Joanna Rapacka also published a book about the previous ages of Croatian History (Rapacka, 2001, 2003). 
Austrian, Italian, and Vatican archives, as well as a wealth of printed materials, contemporary press and extensive multilingual literature (Cetnarowicz, 2001d, 2006b, 2008a). We also owe to this author a number of detailed studies on the subject that have been published in journals and other Polish and foreign publications (Cetnarowicz 1997c, 2001b, 2001e, 2001f, 2001h, 2001i, 2006a, 2007a, 2007c, 2009c, 2011c, 2018). In 2001, an encyclopedic entry on the history of Croatia written by Antoni Cetnarowicz was published in the series Encyklopedia Historyczna Świata [A Historical Encyclopaedia of the World] (Cetnarowicz, 2001a).

In a thorough monograph based on archival sources and literature on the subject, Antoni Cetnarowicz also addressed a topic which is almost completely unknown to Polish readers, i.e. the national revival in Istria in the second half of the $19^{\text {th }}$ c., (Cetnarowicz, 2010b, 2014b). As this book's reviewers noted, not only had this topic not been tackled by Polish historians, but more importantly, some points relevant to this subject matter had also been neglected by Croatian, Italian and Slovene historians. Some more specific themes concerning the national movement in Istria became the subject of several other works by this author (Cetnarowicz, 2006c, 2009e, 2010a, 2015b, 2017a).

Since 1989, several Polish historians have continued or resumed studies on Polish-Croatian relations in the second half of the $19^{\text {th }} \mathrm{c}$. Piotr Żurek, a historian and Slavist connected to the Silesian circles, published several books in Polish and Croatian which presented the Hôtel Lambert faction's relations with the Croats in the mid-1800s, the figure of Bishop Josip Juraj Strossmayer and his relations with Poles, as well as Polish-Croatian relations during the January Uprising of 1863, in particular Eugen Kvaternik's and Dubrovnik's attitude towards the Polish insurrection (Żurek, 2005b, 2008, 2012c, Żurek, Lupis, 2012). After Croatia applied for EU membership, in 2006 the same scholar co-organized the international scientific conference "Poland and Croatia in Central Europe (European integration in tradition and space)", which published its materials a year later (Żurek, 2007). Piotr Żurek also devoted some other studies to Polish-Croatian relations that mainly concerned the activity of the Hôtel Lambert faction among Croats (Żurek, 2005a, 2005c, 2007a, 2007c, 2012a). Stanisław Pijaj, a Kraków-based historian, also discussed the impact of the Hungarian-Croatian agreement of 1868 on the shape of the Galician Diet resolution of 24 September 1868 (Pijaj, 1992)

Meanwhile, the echoes of the Serbian and Croatian nationalist movement in Dalmatia in the Galician press and the attitude of this movement's activists 
towards the January Uprising of 1863 were the topic of several articles penned by Antoni Cetnarowicz and published by Polish and Croatian publishing houses. Adam Świątek presented the image of the uprising in the Bay of Kotor in 1869 in "Gazeta Narodowa" [“The National Gazette”], while Kazimierz Karolczak showed Opatija in the late $19^{\text {th }} \mathrm{c}$. as seen through the eyes of the Polish aristocrats who frequently visited this Adriatic resort (Cetnarowicz 2002b, 2003a, 2011a, 2013b; Świątek, 2017; Karolczak, 2017). We should also mention Tomasz Pudłocki's article about the journey through the Croatian lands in 1909 of the Galician politician and educator, Franciszek Tomaszewski (2016).

The Croatian historians Damir Agičić, Slaven Kale, and Ivan Brlić published valuable articles in Polish about the history of Croatia and Polish-Croatian historical and cultural relations (Agičić, 1998, 2000, 2003, 2007; Kale 2014; Kale \& Brlić, 2017).

Over the last twenty-five years, the topic of Polish-Croatian historical and cultural relations has also appeared in the works of Slavists such as Joanna Rapacka, Maciej Czerwiński, and Sylwia Nowak-Bajcar (Rapacka, 2004; Czerwiński, 2011; Nowak-Bajcar, 2018b).

On June 8-9, 2016, Polish and Croatian Slavists and Historians organized "The Polish-Croatian relations over the centuries. History, culture, literature" [Związki polsko-chorwackie na przestrzeni wieków. Historia, kultura, literatura] session at Jagiellonian University in Cracow. The outcome was the volume Poljskohrvatske veze kroz stoljeća. Povijest, kultura, književnost, published by the Croatian publishing house Srednja Europa (Czerwiński \& Agičić, 2018).

In the period since the political transformation, i.e. after Croatia regained independence, Polish Slavists, especially specialists on Croatia, have been very interested in - and consequently published many works on - the ideas of nation, national awareness and identity. Studies on this subject matter were undertaken by the Slavist circles in Kraków and Warsaw, which resolutely abandoned the old methodology of so-called "central narratives" and included the comparative method and interdisciplinary approach in their research process. In the Slavist circle in Kraków, this subject matter (mainly in the Croatian context) was taken up by Maria Bobrownicka, Maciej Czerwiński, Magdalena Dyras, Aleksandra Borowiec, and Dominika Kaniecka (Bobrownicka, 2002; Czerwiński, 2005, 2007a, 2007b; Dyras, 2002a, 2002c, 2009a; Borowiec, 1992; Kaniecka, 2014).

In the Slavist circle in Warsaw, this research trend was represented by the aforementioned Joanna Rapacka, and at present it is expanded on by 
Maciej Falski, both in terms of methodology and content. His monograph Porzadkowanie przestrzeni narodowej. Przypadek chorwacki [Tidying Up the National Space: The Case of Croatia] is a successful attempt to analyze the issue of the formation of the modern Croatian national awareness. The same author, working in the Team for Studies on Slavic Cultures on the Outskirts of the Habsburg Monarchy at the Institute of Western and Southern Slavic Philology of the University of Warsaw, is the co-writer of two books: Peryferie. Habsbursko-stowiańska historia nieoczywista [The Peripheries. A Not So Obvious Habsburg-Slavic History], in which he painted a portrait of the city and residents of Osijek in Slavonia, and Obcy i obywatele? Słowianie a przemiany konstytucyjne $w$ monarchii habsburskiej w latach 1860-1861 [Outsiders and Citizens? Slavs and Constitutional Transformations in the Habsburg Monarchy in 1860-1861], in which he attempted to explain the attitude of Croats, who were strengthening their national identity, towards Vienna and Pest at the beginning of the Habsburg Monarchy (Falski, 2004, 2008, 2013; Kobylińska, Falski, Filipowiecz, 2016a, 2016b).

\section{Serbian studies}

Over the last twenty-five years, Polish historians and Slavists have not devoted much attention to the history of Serbs and Serbia in the second half of the $19^{\text {th }} \mathrm{c}$. However, Joanna Rapacka, the aforementioned specialist on the history and culture of Southern Slavs, analyzed the history of the Kosovo myth and the development of Serbian anti-Occidentalism in two in-depth studies (Rapacka, 1992a, 1992b).

Polish studies on relations with Serbs in the $19^{\text {th }} \mathrm{c}$. essentially focused on the first half of the 1840s and the activity of the Hôtel Lambert faction. Detailed studies based on extensive queries in Polish, Serbian, French, English and Austrian archives were conducted by Antoni Cetnarowicz, who published his findings in a monograph and in Polish, Austrian, Serbian and Croatian publications. He showed the undeniable role that the group of émigrés gathered around Prince Adam Czartoryski played in the process of modernization of the Serbian state and society, as well as in shaping Serbia's Yugoslavian policy (Cetnarowicz, 1989, 1990b, 1991, 1993a, 1993c, 2003b, 2006d, 2017b). The problems of the genesis and Polish inspirations behind the state document 
published in 1844 - the so-called Načertanije - were addressed by A. Giza and P. Żurek (Giza, 1990b; Żurek 2004).

If we look at just the second half of the $19^{\text {th }} \mathrm{C}$., Polish achievements are much more modest. We owe the image of the history of the Serbian nation and state in Serbian historiography and the role of the Orthodox Church to Dorota Gil, a Kraków-based Slavist (Gil, 1995a, 1995b, 2005a, 2005c). Mirosław Dymarski, a political scientist from the Wrocław circle, discussed the shaping of the political system in Serbia and the foreign policy of Belgrade in the $19^{\text {th }}$ and early $20^{\text {th }} \mathrm{C}$., while Antoni Giza addressed the state of Serbian education and schooling in the $19^{\text {th }}$ c. (Dymarski 2010a, 2010b; Giza 1988, 1998a). In 2018, Dariusz Faszcza, a military historian specializing in Bulgarian problems, published a political and military study on the Bulgarian-Serbian war of 1885, while Dariusz J. Gregorczyk wrote about the Serbian-Turkish war of 1876 (Faszcza, 2018; Gregorczyk, 2010). Piotr Żurek published articles in which he discussed Cardinal Mieczysław Ledóchowski's relations with the Catholic Church in Serbia in the second half of the $19^{\text {th }} \mathrm{c}$., while Stanisław Pijaj described the reputable Serbian Hristić family's largely unknown relations with Poland (Żurek, 2003, 2017; Pijaj, 2017).

We should also mention historians and political scientists who study the problems of Kosovo and Serbian-Albanian relations. Wojciech Szczepański was the only Polish scholar to study these issues with regard to the $19^{\text {th }}$ century (Szczepański, 2006, 2007, 2009, 2010); we should also mention a valuable article written by Andrzej Malinowski concerning the system of millets in Kosovo (Malinowski, 2012). We also should not forget the works focusing on the $20^{\text {th }} \mathrm{c}$. or contemporary times that also included the $19^{\text {th }}$-century context that were penned by Danuta Gibas-Krzak (2009), Maciej Skorczewski (2013), Irena StawowyKawka (2002, 2014, pp. 23-49), and Sylwia Nowak-Bajcar (1999).

Studies on the Serbian historical novel were the subject of Bogusław Zieliński's monograph, while M. Koch presented the main figures of Serbian Romanticism in contemporary popular literature (Zieliński, 1998; Koch, 2011). The Slavist Maria Dąbrowska-Partyka penned an interesting sketch of the history of Hungarian Serbs and their role in the process of the shaping of the modern Serbian identity (Dąbrowska-Partyka, 2007). Sylwia Nowak-Bajcar, who focuses on $20^{\text {th }} \mathrm{c}$. Serbian literature, is the author of some works about the $19^{\text {th }}$ c. (Nowak-Bajcar, 2010, 2017, 2018a). Among Slavists, Damian Kubik also wrote about the Dalmatian Serbs at that time (Kubik, 2017b). 


\section{Bosnian studies}

In the second half of the $19^{\text {th }} \mathrm{C}$., Galicia as well as Bosnia and Herzegovina found themselves within the borders of Austria-Hungary, which created a number of points of contact between Poles and Southern Slavic nations living in the former Ottoman province, namely between Serbs, Muslims and Croats. In comparison to studies on the history of Bosnia in the $20^{\text {th }} \mathrm{c}$., the second half of the $19^{\text {th }} \mathrm{c}$. is not a well-researched topic in Polish historiography. In 2002, Antoni Giza wrote the following in his introduction to a synthetic work on the history of Bosnia in the period in question:

The idea of writing a monograph on the history of Bosnia and Herzegovina in the $19^{\text {th }}$ and early $20^{\text {th }} \mathrm{c}$. (until the assassination in Sarajevo) was justified by the level of knowledge of the history of these lands in our country. I believe that most Readers will agree with me when I say that this level is rather low. At the turn of millennia, Poles mainly attach importance to learning the history of Western Europe and North America and pay little attention to Southern Slavic countries (Giza, 2002a, p. 7).

This statement seems to be valid at present as well, even though it was made almost sixteen years ago.

An overview of Polish studies on Bosnia published in Polish literature was conducted by Slavists: in 2003, a team consisting of Krzysztof Wrocławski, Magdalena Bogusławska and Norbert Różycki prepared a bibliographic guide with commentaries entitled Polacy w Bośni, Polacy o Bośni [Poles in Bosnia, Poles on Bosnia]. Due to the fact that this work was prepared by philologists, the authors focused on language in their analyses (Wrocławski, Bogusławska \& Różycki, 2003). There is no work that reviews historical publications on the topic.

However, this does not mean that Polish humanities concerning Bosnia in the second half of the $19^{\text {th }} \mathrm{c}$. have not developed over the last twenty-five years. Since 1989, Polish historians have been keenly interested in, e.g., the problem of Polish settlers in Bosnia and Herzegovina after this province was occupied by Austria-Hungary. Prior to 1878, northern Bosnia (the territories from the River Sava to the city of Banja Luka) was sparsely populated. The situation changed in the aftermath of the Austrian-Hungarian occupation and the announcing of a settlement program. A period of colonization started in 1895 and lasted for a decade. Members of nations inhabiting the other parts of the Habsburg State, including Poles, came to settle on Bosnian lands; encouraged by the privileges and land offered to them, they volunteered to go to 
the province and several dozen Polish settlements were established in northern Bosnia as a result. At the same time, Poles were part of the administrative apparatus of the province. Before the outbreak of World War I, almost half of the officials in Bosnia and Herzegovina came from the other Slavic states of the monarchy, especially those of Catholic and Uniate denominations, and many Poles (Вяземская, 2011, p. 168). The Polish historians who have addressed this subject matter include Tomasz Jacek Lis (2012, 2013, 2014a, 2014b, 2015a, 2015b, 2016; Lis \& Maleszka, 2015), Franciszek Kwaśniak (Kwaśniak \& Orlovac, 2013), Jan Bujak (2012, 2014, 2017), Magdalena Bogusławska (2005a, 2005b, 2006), Dariusz J. Gregorczyk (2010, 2011, 2012), Łukasz Chimiak (2013), Józef Mandziuk (2009), Katarzyna Pielech (2008) and Paulina Wichniewicz (2015, 2017). Apart from these authors' original works, source editions of recollections of Poles active in Bosnia in the second of the $19^{\text {th }} \mathrm{c}$. were also published (Krajewska [z Kosmowskich], 1989)5. Prior to 1989, the topic of Polish settlers in Bosnia was practically unrecognized, but after the political transformation Polish scholars (mainly historians and ethnologists) largely succeeded in filling this gap in Polish historiography.

With regard to Polish-Bosnian relations, we should also note the problem of the Hôtel Lambert faction's activity in Bosnia in the 1840s, which tapered off after the Spring of Nations. Paralleling the earlier studies of Jerzy Skowronek, Piotr Żurek has been researching this topic and publishing in Polish, Croatian and Bosnian, although his studies focus on Croatian affairs at the beginning and first half of the 19th c. and, more recently, on the 20th century (Zurek, 2012a, 2015, 2017).

The other areas of Polish studies on the political and social history of Bosnia in the second half of the $19^{\text {th }} \mathrm{c}$. are evidently overshadowed by studies on the $20^{\text {th }} \mathrm{c}$. and contemporary times, especially the war in the $1990 \mathrm{~s}$ and its aftermath. The only scholar to attempt a synthetic approach to this period was Antoni Giza, who penned monographs and articles about Bosnia in the second half of the $19^{\text {th }} \mathrm{c}$. (Giza 2002a, 2002b, 2002c). Other authors of valuable publications are Aleksandra Stankowicz and Andrzej Dziadzio, who wrote about Bosnia during the Habsburg period, and Mateusz Maleszka, who wrote about Bosnian Jews during the period in question, among others (Stankowicz, 1996, 1997, 2003, 2004; Dziadzio, 2017; Maleszka, 2015; Lis

${ }^{5}$ Dušan Drljača, a Serbian scholar who focuses on ethnological problems, also published a monograph on this topic in Polish (Drljača, 1997). 
\& Maleszka, 2015). Meanwhile, travel accounts about Bosnia in the $19^{\text {th }} \mathrm{c}$. have attracted the interest of philologists. We should mention articles written by Krystyna Pieniążek-Marković (2014, 2016), Mateusz Seroka (2011, 2013), Marek M. Dziekan (2011), Milica Jakóbiec-Semkowa (2016a, 2017a), and Maciej Falski (2007). With regard to scholars who focus on the $20^{\text {th }} \mathrm{c}$., it is worth noting Danuta Gibas-Krzak, whose synthetic history of Bosnia includes a long chapter on the second half of the $19^{\text {th }}$ c. (Gibas-Krzak, 2016). Additionally, this political scientist, who is based in the city of Częstochowa, is the author of an article about the twilight of the Ottoman rule in this area (Gibas-Krzak, 2015). Scholars who study the topic of the shaping of the Muslim/Bošnjaci identity also focus on the $20^{\text {th }} \mathrm{c}$., but they always refer to the second half of the $19^{\text {th }} \mathrm{c}$. to provide the necessary context for the processes they discuss (Muś, 2013; Filcek, 2011; Balcer, 2008).

Since 1989, Polish studies on Bosnia in the second half of the $19^{\text {th }} \mathrm{c}$. have mainly focused on the topic of the Austrian-Hungarian colonization program, which was the most important point of Polish-Bosnian contacts at that time. Polish studies on the political and social history of Bosnia in the $19^{\text {th }} \mathrm{c}$. are overshadowed by interest in the $20^{\text {th }} \mathrm{c}$. and contemporary times, even though the co-existence of Poles from Galicia and the inhabitants of Bosnia for over thirty years created many other points of political, social, scientific and cultural contact. At the same time, there is little interest in the first three decades of the history of Bosnia during the period in question (1848-1878), when the province was under Ottoman rule and Polish-Bosnian contacts were rather limited.

Like Bosnia and Herzegovina, Sandžak (which was known as the Sandžak of Novi Pazar at that time) was under Austrian-Hungarian occupation in 1878-1908. Studies on this territory usually focus on Muslims/Bošnjaci. For these two reasons, we decided to discuss Polish literature in this area in the $19^{\text {th }} \mathrm{c}$. together with Bosnia, even though after the Balkan wars Sandžak was divided between Serbia and Montenegro.

Studies on Sandžak mainly focus on the $20^{\text {th }} \mathrm{c}$. and contemporary times, while the second half of the $19^{\text {th }} \mathrm{c}$. is on the margin of these reflections and merely provides the context or introduction to the topic. The development of national identity among the Muslim inhabitants of this territory is at the center of scholars' attention. We should firstly mention a book written by Krzysztof Marcin Zalewski entitled Naród, religia, rasa: muzułmańskie ideologie i ruchy narodowe pogranicza w Południowo-Wschodniej Europie: przykład Sandżaka 
nowopazarskiego w XX wieku [Nation, Religion, Ethnicity. Muslim Ideologies and National Movements in the Borderland of South-Eastern Europe: The Case of the Sandžak of Novi Pazar in the $20^{\text {th }}$ Century], which includes chapters that introduce the period in question (Zalewski, 2010). Texts which focus on contemporary topics but also include more general remarks on the discussed period have been penned by Dorota Gil, a philologist, and Anna Jagiełło-Szostak, a political scientist (Gil, 2007; Jagiełło-Szostak, 2015). Sandžak in the $19^{\text {th }} \mathrm{C}$. is another topic which remains practically unresearched by Polish humanities.

\section{Montenegrin studies}

Polish studies on Montenegro in the second half of the $19^{\text {th }} \mathrm{c}$. were practically non-existent in communist times, and they have not developed since 1989. The country continues to hold the interest of only Slavists and political scientists who focus on the $20^{\text {th }} \mathrm{c}$. or contemporary times. In 2007, two philologists, Krzysztof Wrocławski and Magdalena Bogusławska, prepared a valuable analysis of Polish studies on Montenegro, but it does not contain any information relevant to the second half of the $19^{\text {th }} \mathrm{c}$. and early $20^{\text {th }} \mathrm{c}$. (Wrockawski, Bogusławska, 2007). The situation has not changed. We should mention an article about the 1876 war between Turkey and Serbia and Montenegro by Dariusz J. Gregorczyk (2010), and a paper by Magdalena Bogusławska (2006) about Polish travel literature concerning Montenegro from the end of the $19^{\text {th }}$ century. The topic of Montenegro during this period was also addressed in articles written by Wojciech Szczepański (2013), Mirosław Dymarski (2017b), Piotr Żurek (2012b, 2013), and Wiktor Hedba (2012), but none of these texts focuses strictly on the second half of the $19^{\text {th }} \mathrm{c}$.

\section{Macedonian studies}

Studies on the history of Macedonia lead to a number of problems related to the fact that Macedonia is one of the youngest European nations, and its status in the second half of the $19^{\text {th }} \mathrm{c}$. is debatable. In a sense, Polish humanities reflects this problem. Following in the Bulgarian and Greek footsteps, some scholars claim 
that a separate Macedonian nation did not exist during that period (and does not even exist at present); others, like Irena Stawowy-Kawka, point to the $1860 \mathrm{~s}$ as the time when we can start to speak of a Macedonian nation; still others, for instance Piotr Majewski, identify the period after 1945 as the beginning of the shaping of a separate Macedonian nation. The second half of the $19^{\text {th }} \mathrm{c}$. is key for Macedonia and Macedonians in terms of the contemporary history of this land, as well as social and identity changes among the people who inhabit it (Czamańska \& Szulc, 2002, pp. 21-33; Miodyński, 2002, pp. 75-89).

Since 1989, Slavic philologists have prepared bibliographies and texts summarizing the state of Polish studies on Macedonia. We should mention an exhaustive book written by Krzysztof Wrocławski, Magdalena Bogusławska and Ewa Wróblewska-Trochimiuk (2009) (which includes a list of works and studies covering the period from the beginning of Polish interest in Macedonian affairs until 2009), as well as articles published by Lilianna Miodońska (2007) and Lilla Moroz-Grzelak (2015). Historians have not yet attempted to prepare similar works.

Speaking of studies on Macedonia in the second half of the $19^{\text {th }} \mathrm{c}$. that have been conducted since 1989, there is an important group of pro-Bulgarian historians who assume that a separate Macedonian nation did not exist during that time (and perhaps still does not exist) but was part of the Bulgarian nation. The books and articles written by Antoni Giza (1996, 1998b, 1998c, 1998d, 2001b, 2001d, 2003) and Andrzej Malinowski (2006, 2012b, 2014) make that assumption, and their works can be qualified as part of Polish historiography on Bulgarian affairs in the second half of the $19^{\text {th }} c .^{6}$ Jarosław Rubacha is slightly more cautious in this regard, although in the end he supports the idea of a very close connection between Macedonians and Bulgarians in the second half of the $19^{\text {th }}$ c. (Rubacha, 2004, pp. 42-63, 2012, pp. 267-316). In the case of Antoni Giza this view gradually evolved and he ended up in a clearly proBulgarian position, which he wrote about in 2003:

This book [Bułgaria i problem macedonski od poczatku XVIII do lat trzydziestych XX wieku] [Bulgaria and the Macedonian Problem from the Early $18^{\text {th }} \mathrm{c}$. to the 1930s] refers to my previous monographs on these topics. Firstly, to the work Ziemie macedońskie na przełomie XIX i XX wieku [Macedonian Lands at the Turn of the $19^{\text {th }}$ and $20^{\text {th }}$ Century] - unfortunately written under a strong influence of Macedonian his-

6 The Greek perspective is much less often represented in Polish historiography. It is worth noting the translation of the book by Martis Nikolaos; however, it contains only a few pages about the second half of the $19^{\text {th }} \mathrm{C}$. (Nikolaos, 1993). 
toriography - published in 1996, which was badly flawed due to my lack of access to Bulgarian sources. It was not until I published the next monograph, Państwa bałkańskie wobec kwestii macedonskiej w latach 1878-1918 [Balkan States and the Macedonian Problem in 1878-1918], two years later, that I was able to correct many previous opinions, expressed under the misleading influence of Macedonian historiography; the historical truth emerging from the Bulgarian sources could in no way be challenged by biased, fabricated sources from Yugoslavia, clumsily supporting Macedonism [i.e. the idea of the separateness of the Macedonian nation - author's note].

Bulgarian sources and documents explicitly show that Macedonia was predominantly inhabited by a Bulgarian population [...] (Giza, 2003, p. 8).

Another good example of this trend is a source edition concerning Macedonia, published as the second volume of Historia Bułgarii 1870-1915: materiaty źódłowe z komentarzami [A History of Bulgaria 1870-1915. Source Materials with Commentaries], written by Jarosław Rubacha and Andrzej Malinowski; this is in fact a selection of Bulgarian sources (or ones which share the Bulgarian vantage point) concerning Macedonia at that time (Rubacha \& Malinowski, 2007). It should be emphasized that adopting this viewpoint in no way lessens the value of these works, and the studies on Macedonia's history in the second half of the $19^{\text {th }} \mathrm{c}$. conducted by Giza, Rubacha and Malinowski should be considered the most valuable achievements of Polish historiography since 1989. It is worth noting that this trend gained recognition in Bulgaria, as illustrated by the fact that Antoni Giza's monograph about the Balkan states and the Macedonian problem, which basically focused on Bulgarian politics, was translated into Bulgarian (Гиза, 2001).

Other scholars have also focused on Macedonia in the second half of the $19^{\text {th }} \mathrm{c}$. in a handful of articles, looking at the history of this area from an external perspective. Mirosław Dymarski, a political scientist, analyzed the image of Macedonians in Serbian diplomatic documentation from the early $20^{\text {th }} \mathrm{C}$. (Dymarski, 2017), while Jędrzej Paszkiewicz, a historian, looked at Macedonia through the lens of Italian politics (Paszkiewicz, 2005). Also, Rigels Halili is a Polish researcher of Albanian origin from Warsaw University; he is the author of an article about the Albanian National Revival and its relations to Macedonia (Halili, 2002).

The works in Polish which accept the separateness of the Macedonian nation describe the second half of the $19^{\text {th }} \mathrm{c}$. only fragmentarily and mostly focus on the $20^{\text {th }} \mathrm{c}$. Extensive fragments concerning this period were included in synthetic historical works about Macedonia penned by Irena Sta- 
wowa-Kawka $(2000,2014)^{7}$, Paweł Olszewski (2010), and Waldemar Potkański (2011). Representatives of other disciplines have also been active in this field; they include Piotr Majewski (2013, 2015), an anthropologist, Maciej Kawka and Paweł Płaneta (2013), who are both media specialists, Lilla Moroz-Grzelak $(2004,2006)$ and Lech Miodyński (2011), who are both Slavists.

The topic of Polish-Macedonian relations in the second half of the $19^{\text {th }} \mathrm{c}$. is very poorly examined by Polish humanities and this situation has not changed since 1989. If we disregard the works about the Polish aspects of the KresnaRazlog Uprising, which usually assume that the movement was Bulgarian in nature (Klejn, 2005), we are left only with Krzysztof Stępniak's publications about Polish reactions to the events in Macedonia in the early $20^{\text {th }} \mathrm{C}$. (2014).

The modest achievements of Polish humanities with regard to Macedonia in the second half of the $19^{\text {th }} \mathrm{c}$. stem from a lack of Polish-Macedonian points of contact. Polish historians who specialize in the $19^{\text {th }} \mathrm{c}$. usually conclude that the Slavs inhabiting Macedonia in that period were Bulgarians, and events such as the Kresna-Razlog Uprising or the Ilinden Uprising were part of the Bulgarian national liberation movement. They use sources of Bulgarian origin and at the same time study the history of Bulgaria and look at the history of Macedonia through this lens. Interpretations in which these events are related to the emerging Macedonian nation can be found in Polish literature in the works of scholars who focus on the $20^{\text {th }} \mathrm{c}$. or contemporary times, which is why they are described in a general or fragmentary way. Few of these scholars are historians - in fact, Irena Stawowa-Kawka is the only one that comes to mind - and the majority of such studies are carried out by political scientists, philologists and ethnologists.

\section{The problems of national identity and unionism ideas}

The war which broke out in Yugoslavia in the early 1990s and led to the collapse of the state drew the attention of Polish historians, Slavists and political scientists to this area and prompted a number of research projects and studies on the genesis of conflicts in the Balkans, issues related to national identity, and

7 It is worth noting the books edited by Irena Stawowy-Kawka; however, they mostly focused on the $20^{\text {th }}$ century. (Stawowy-Kawka (ed.), 2005, 2007, 2008). 
the idea of unionism among Southern Slavs. The political atmosphere which accompanied these events on the European and global scale was not conducive to these efforts, and the world media competed against each other in depicting a negative image of the Balkans. As Bogusław Zieliński observed, this led to "stereotyping Southern Slavs in the Polish political discourse" (Zieliński, 2009). Deep changes also occurred in the historiographies of Southern Slavic countries with regard to the history of the $19^{\text {th }} \mathrm{c}$., which is the topic of our article. The historiographies during the period of political transformation and the fifteen years that followed were analyzed by Antoni Cetnarowicz (2013c).

In the aftermath of increased public interest and demand, several books were published at that time by Antoni Giza (1994), Leszek Podhorodecki (2000), Marek Waldenberg (2005), Wiesław Walkiewicz (2003), and Izabela Rycerska (2003), which generally addressed problems related to the history of former Yugoslavia and its collapse.

Slavist circles, especially those in Kraków and Poznań, played an active role in the ongoing discourse about this subject matter. In the former circle, the discourse resulted in two positions focusing on the issue of changes in the awareness and spiritual culture of the former Yugoslavian nations and the problem of reinterpreting the cultural tradition in the post-Yugoslavian countries (Kornhauser, 1999; Dąbrowska-Partyka, 2005). In the Poznań circle, a position emerged that focused on the national and supra-national model of culture in Central Europe and on the Balkan Peninsula (Zieliński, 2002).

Historians, although they were still a small group, continued studies on the development of modern ideas of a nation, state, and Pan-Slavic unity, and the Polish presence in these processes. In the last years of his life, Jerzy Skowronek $(1990,1991,1992,1996,1997)$ took to studying the Polish attitude towards Balkan national movements, as well as the attitude of Balkan nations and states towards the January Uprising and the vision of East-Central Europe in Adam J. Czartoryski's programs. Antoni Giza (1992, 1997), apart from authoring the aforementioned book about the birth and collapse of Yugoslavia, also presented the origins and development of the Yugoslavian idea, including its Polish aspects, while Piotr Żurek (2007b) discussed the ongoing historiographic debates about the emergence of Yugoslavism.

As we have mentioned, as a result of the situation in the Balkans following the collapse of Yugoslavia, matters related to national awareness and identity, historical notions, as well as the shaping of unionism and unification ideas in the $19^{\text {th }} \mathrm{c}$. became the center of attention for historians and Slavists 
alike. As for historians, these topics were continued or resumed by Henryk Batowski (1994), Antoni Cetnarowicz (2004, 2008b, 2009b, 2009d, 2012, 2014a), Antoni Giza (1993a, 1993b), Elżbieta Znamierowska-Rakk (2000), and Jarosław Kilias (2000). Antoni Cetnarowicz (1995, 1997b, 1998a, 1998b, 2005, 2013a, 2016d, 2016c) endeavored to show the Polish contribution to the development of national movements and the shaping of the idea of unity among Southern Slavs in several of his works.

Slavists turned out to be a much more active group during that period with regard to studying problems concerning national and cultural awareness, identity, and the idea of Slavic unity.

In the Slavist circle in Kraków, such studies were very successfully continued by the nestor Maria Bobrownicka (1992, 1995, 1997, 2006, 2002), who was the author of a number of works, publisher of post-conference materials, and initiator and co-organizer of the memorable symposium in Castel Gandolfo in 1996, which was under the patronage of Pope John Paul II, who also participated (Bobrownicka, Suchanek \& Ziejka, 1997).

The subjects of national identity and Slavic unity have also been addressed by other representatives of this circle: Maria Dąbrowska-Partyka $(2003,2005)$, Magdalena Dyras (2002b, 2004, 2007, 2009a, 2009b, 2015), Maciej Czerwiński (2005, 2012, 2014a, 2014b), Dorota Gil (2002, 2005b, 2013, 2017), Aleksandra Borowiec (1992, 2005), Sylwia Nowak-Bajcar (2012a, 2012b), and Damian Kubik $(2012,2015)$. The problem of changes in the cultural awareness of the former Yugoslavian nations was discussed in a volume edited by Julian Kornhauser (1999).

The academic circles in Poznan and Warsaw were also very active in this area. In Poznań, Bogusław Zieliński’s works and activity concerning the problem of national identity are the most notable; the author was a co-organizer of important publishing initiatives showing models of culture in Central Europe and on the Balkan Peninsula, as well as the history of the idea of Slavic unity in the context of the changes which took place in the aftermath of the war in Yugoslavia in the 1990s (Zieliński 2002a, 2002b, 2012; Mikołajczak, Szulc \& Zieliński, 2004). J. Grela (1996), also based in Poznań, penned an article about the idea of Slavic unity in the early $20^{\text {th }} \mathrm{c}$., published in "Acta Uniwersytetu im. Adama Mickiewicza" ["Records of the Adam Mickiewicz University"].

In the Warsaw circle, apart from the works of the three Slavists mentioned above who work in the Team for Studies on Slavic Cultures on the Outskirts of the Habsburg Monarchy, the problems of Slavic unity, especially in the Croa- 
tian context, were studied by Lilla Moroz-Grzelak (2011, 2018), while Joanna Goszczyńska edited a volume about the cultural identity of Slavs (Goszczyńska, 2005).

Among Silesian Slavists, Barbara Czapik-Lityńska (2007) and Emil Tokarz studied the problem of the national identity of Southern Slavs (Czapik-Lityńska \& Tokarz, 1992).

We should also note a position which focuses on the image of Southern Slavs in Polish literature in the $19^{\text {th }}$ and $20^{\text {th }}$ c. (Stępnik \& Gabryś, 2010)

\section{Summary}

Studies on the relations between Southern Slavs and Poles have attracted considerable interest from Polish historians, while since 1989 topics strictly related to the history of the nations and states of former Yugoslavia in the second half of the $19^{\text {th }} \mathrm{c}$. have remained the domain of Slavists. More than half of the mentioned historical works were penned by philologists, and many others were by political scientists; on one hand, this leads to the greater interdisciplinarity of such works, but on the other hand many of them were not based on archive queries or a new corpus of sources. The popularity of Southern Slavic topics related to the Polish public's interest in the war in former Yugoslavia was rather limited to the 1990s; it had an influence on political scientists and Slavists, and only to a lesser extent on historians. Moreover, these events did not have a positive impact on the objectivity of the discourse as studies on the second half of the $19^{\text {th }} \mathrm{c}$. still remain overshadowed by studies on the $20^{\text {th }} \mathrm{c}$. We should also note here that Polish historians are generally much more interested in the problems of Eastern Slavs than Southern ones.

After 1989, Polish historians studying the nations which were later to become Yugoslavia during the second half of the $19^{\text {th }} \mathrm{c}$. turned out to be more prolific than they had been prior to the political transformation. Although in communist times there was a tendency to study Slavdom in the spirit of strengthening relations among "sister nations", Yugoslavia, which was not part of the Eastern Bloc, was not included in this as fully as, e.g., Eastern Slavs. This translated into restrictions on foreign travel. The political transformation in Poland created new conditions for taking on studies on a number of topics. There has been a visible development of historiography concerning Croatian 
affairs and Polish-Bosnian relations resulting from the Austrian-Hungarian colonization. This has stemmed from the greater mobility of Polish scholars, who now have much brighter prospects of working in foreign archives, libraries and institutions. Moreover, an increasing number of books and articles are available in digital form. On the other hand, since the 1990s the number of published books and scholarly texts has increased rapidly, as has the number of higher education institutions, journals, and publishing houses in Poland, which in itself it does not translate into a higher quality of research, but it does have an influence on the number of available publications.

At the same time, some topics remain obscure, such as Serbian and Montenegrin affairs, which seem to be completely neglected in comparison with studies on Croatian topics. Slovene and Bosnian studies have made a lot of progress, but there are still many unresearched areas there. In the case of Macedonian affairs, a problem of a different nature has arisen: they are often treated as an inseparable part of the history of Bulgaria.

\section{BIBLIOGRAPHY}

Agičić, D. (1998). Krótki rys stosunków chorwacko-polskich na przestrzeni dziejów. Proglas, $8,6-8$.

Agičić, D. (2000). Echa powstania styczniowego w Chorwacji. Prace Komisji Środkowoeuropejskiej PAU, 8, 39-48.

Agičić, D. (2003). Idee niepodległościowe wśród Chorwatów do I wojny światowej (1860-1914). In I. Stawowy-Kawka \& W. Rojek (Eds.), Państwa europejskie na drodze do niepodległości ( $w$ drugiej połowie XIX i XX wieku). Studia ofiarowane Profesorowi Marianowi Zgórniakowi (pp. 35-40). Kraków: Historia Iagellonica.

Agičić, D. (2007). Kongresi jugoslavenskih povjesničara - mjesto suradnje Ili polje sukoba. In I. Stawowy-Kawka (Ed.), Obraz konfliktów miedzy narodami słowiańskimi w XIX i XX wieku w historiografii (pp. 117-130). Kraków: Wydawnictwo Uniwersytetu Jagiellońskiego.

Balcer, A. (2008). Zarys rozwoju bośniackiej tożsamości narodowej w Bośni. In P. Żurek (Ed.), Tantum Historiae. Księga ofiarowana profesorowi Mieczysławowi Tantemu w osiemdziesiata rocznicę urodzin (pp. 25-41). Bielsko-Biała: Media Silesia.

Batowski, H. (1938). Państwa bałkańskie 1800-1932. Zarys historii dyplomatycznej i rozwoju terytorialnego. Kraków: Skł. gł.: Kasa im. Mianowskiego w Warszawie.

Batowski, H. (1994). Czy Austro-Węgry mogły przetrwać? Przegląd Polityczny, 7, 17-33.

Bobrownicka, M. (1992). Antyteza słowiańsko-europejska. Z problematyki stereotypu. In T. Dąbek-Wirgowa \& A. Z. Makowiecki (Eds.), Europa w kulturach stowiańskich (pp. 13-19). Warszawa: Uniwersytet Warszawski, Wydział Polonistyki. 
Bobrownicka, M. (1995). Narkotyk mitu. Szkice o świadomości narodowej i kulturowej Słowian zachodnich i południowych. Kraków: Universitas.

Bobrownicka, M. (1997). Utopie i polityka. Relacje naród-państwo w ideologii odrodzenia narodowego Słowian Zachodnich i Południowych. In M. Bobrownicka, L. Suchanek \& F. Ziejka (Eds.), Współcześni Słowianie wobec własnych tradycji i mitów. Sympozjum w Castel Gandolfo w dniach 19-20 maja 1996 (pp. 23-38). Kraków: Universitas.

Bobrownicka, M. (2002). Lud - Naród - Społeczeństwo. Kategorie zbiorowej tożsamości w odrodzeniu narodowym Słowian habsburskich. Pamiętnik Słowiański, 52, 3-20.

Bobrownicka, M. (2003). Pogranicze w centrum Europy. Slavica. Kraków: Universitas.

Bobrownicka, M. (2006). Patologie tożsamości narodowej w postkomunistycznych krajach słowiańskich. Kraków: Universitas.

Bobrownicka, M. (Ed.). (1992). Mity narodowe w literaturach słowiańskich. Studia poświęcone XI Międzynarodowemu Kongresowi Slawistów w Bratysławie. Kraków: Uniwersytet Jagielloński.

Bobrownicka, M., Suchanek, L., \& Ziejka, F. (Eds.). (1997). Współcześni Słowianie wobec własnych tradycji i mitów. Sympozjum w Castel Gandolfo w dniach 19-20 maja 1996. Kraków: Universitas.

Bogusławska, M. (2005a). Obraz stosunków międzywyznaniowych w Bośni i Hercegowinie końca XIX wieku w zapisach z podróży ks. Marcina Czermińskiego. Pamiętnik Słowiański, 55(1), 59-76.

Bogusławska, M. (2005b). Tatuaż w komunikacji międzykulturowej w Bośni i Hercegowinie końca XIX wieku. In J. Goszczyńska (Ed.), Problemy tożsamości kulturowej w krajach słowiańskich (Vol. 3. Jej znaki i symbole, pp. 207-224). Warszawa: ISZiP.

Bogusławska, M. (2006). Wyprawy do źródeł czasu: obraz Czarnogóry w polskich relacjach podróżniczych z XIX wieku. In P. Bunjak (Ed.), 110 godina polonistike u Srbiji (pp. 277-285). Beograd: Slavističko društvo Srbije.

Borowiec, A. (1992). Mit Ilirii - czy chorwacki odwrót od Europy? In T. Dąbek-Wigrowa \& A. Makowiecki (Eds.), Kategorie Europy w kulturach słowiańskich (pp. 139-144). Warszawa: Uniwersytet Warszawski, Wydział Polonistyki.

Borowiec, A. (2005). Reinterpretacje kultury dawnej we współczesnej kulturze chorwackiej. In M. Dąbrowska-Partyka (Ed.), W poszukiwaniu nowego kanonu. Re-interpretacje tradycji kulturalnej w państwach postjugosłowiańskich po 1995 roku (pp. 339-350). Kraków: Wydawnictwo Uniwersytetu Jagiellońskiego.

Bujak, J. (2012). Galicjanie i Serbowie = Galicjani i Srby. Jelenia Góra: Wydawnictwo Ad Rem. Bujak, J. (2014). Galicjanie i Serbowie, Part 2: W Bośni. Jelenia Góra: Wydawnictwo Ad Rem. Bujak, J. (2017). Polskie parafie w Bośni w latach 1891-1946. Jelenia Góra: Wydawnictwo Ad Rem.

Cetnarowicz, A. (1989). Fürst Miloš Obrenović in den ersten Konzeptionen der Balkanpolitik des Hotels Lambert. Österreichische Osthefte, 31(3), 373-381.

Cetnarowicz, A. (1990a). Słoweński ruch narodowy i jego stosunek do spraw polskich 1848-1879. Kraków: Uniwersytet Jagielloński.

Cetnarowicz, A. (1990b). Udio i uloga Hotela Lambert u političkoj srpskoj kizi 1842-1843. godine. Historijski zbornik, 43, 271-285. 
Cetnarowicz, A. (1991). Akcja dyplomatyczna obozu Czartoryskiego na rzecz utrzymania ks. Aleksandra Karadziordzievicia na tronie serbskim w roku 1843. Studia Polono-Danubiana et Balcanica, 4, 7-23.

Cetnarowicz, A. (1992a). Slovenci in politika polskih poslancev v Državnem zboru v letih 1867-1868. Zgodovinski časopis, 46(1), 33-39.

Cetnarowicz, A. (1992b). Stosunek Słowenii do spraw polskich w połowie XIX wieku. In J. Toporišič, T. Lopar \& F. Jakopin (Eds.), Miklošičev zbornik. Mednarodni simpozij v Ljubljani od 26. Do 29. julija 1991 (pp. 603-616). Ljubljana: Slovenska akademija znanosti in umetnosti v Ljubljani.

Cetnarowicz, A. (1993a). Misja Michała Czajkowskiego w Belgradzie w roku 1843 i jej rezultaty. In W. Frazik (Ed.), Przez dwa stulecia XIX i XX. Studia historyczne ofiarowane Prof. Wacławowi Felczakowi (pp. 169-182). Kraków: Instytut Teologiczny Księży Misjonarzy.

Cetnarowicz, A. (1993b). Słoweńskie programy narodowe do roku 1914. Prace Komisji Środkowoeuropejskiej PAU, 1, 33-50.

Cetnarowicz, A. (1993c). Tajna dyplomacja Adama Jerzego Czartoryskiego na Bałkanach. Hotel Lambert a kryzys serbski w latach 1840-1844. Kraków: Uniwersytet Jagielloński.

Cetnarowicz, A. (1993d). “Zjednoczona Słowenia”. Z problematyki słoweńskiego ruch narodowego w połowie XIX wieku. Balcanica Posnaniensia. Acta et studia, 6, 63-77.

Cetnarowicz, A. (1994). Slovenci in vprašanje gališke avtonomije v letih 1868-1874. Zgodovinski časopis, 48(4), 519-535.

Cetnarowicz, A. (1995). Wkład Polaków w kształtowaniu się idei jedności wśród Słowian południowych. Studia Polono-Danubiana et Balcanica, 7, 33-44.

Cetnarowicz, A. (1996a). Die Polen und die Slowenen in der Habsburgermonarchie. Ein Blick auf die wechselseitigen Beziehungen der beiden Nationen in der zweiten Hälfte des 19. Jahrhunderts. Studia Austro-Polonica, 5, 229-250

Cetnarowicz, A. (1996b). Słoweńcy i Niemcy w XIX wieku. Z dziejów trudnego współżycia. In M. Bobrownicka (Ed.), Symbioza kultur słowiańskich i niesłowiańskich w Europie Środkowej (pp. 107-116). Kraków: Universitas.

Cetnarowicz, A. (1997a). Polacy i Słoweńcy w monarchii habsburskiej. Uwagi na temat wzajemnych stosunków w drugiej połowie XIX wieku. Studia Austro-Polonica, 5, 203-220.

Cetnarowicz, A. (1997b). Udział Polaków w rozwoju ruchów narodowych i idei zjednoczeniowej wśród Słowian południowych. In M. Bobrownicka, L. Suchanek \& F. Ziejka (Eds.), Współcześni Słowianie wobec własnych tradycji i mitów. Sympozjum w Castel Gandolfo w dniach 19-20 maja 1996 (pp. 105-118). Kraków: Universitas.

Cetnarowicz, A. (1997c). Z problematyki ruchu narodowego w Dalmacji w XIX wieku. Między autonomią a zjednoczeniem z Chorwacją i Slawonią. Studia Polono-Danubiana et Balcanica, 12, 27-35.

Cetnarowicz, A. (1998a). Das Verhältnis der polnischen Abgeordneten zu den südslawischen Völkern im österreichischen Reichsrat in den 70-er Jahren des 19. Jahrhunderts. In Z. Kowalska (Ed.), Aus der Geschichte Österreichs im Mitteleuropa (pp. 127-147). Wien: Janineum Verlag.

Cetnarowicz, A. (1998b). Die Nationalbewegung der Südslawen und die Polen. In H. Timmermann (Ed.), Entwicklung der Nationalbewegungen in Europa 1850-1918 (pp. 237-247). Berlin: Duncker\&Humblot. 
Cetnarowicz, A. (1998c). Opinie prasy galicyjskiej na temat walki narodowej Słoweńców w pierwszych latach dualizmu. In A. Giza (Ed.), Rosja-Polaka-Bałkany w XVIII-XX wieku. Ksiegga pamiątkowa ofiarowana Prof. Mieczysławowi Tantemu (pp. 211-226). Szczecin: Wydawnictwo Naukowe Uniwersytetu Szczecińskiego.

Cetnarowicz, A. (2001a). Chorwacja. In Encyklopedia Historyczna Świata (Vol. 8, Part 1. Europa, pp. 130-147). Kraków: Opres.

Cetnarowicz, A. (2001b). Dalmacja jako teren wyprawy dywersyjnej przeciwko Austrii na początku lat sześćdziesiątych XIX wieku. In I. Stawowy-Kawka \& W. Rojek (Eds.), Państwa europejskie na drodze do niepodległości ( $w$ drugiej połowie XIX i XX wieku). Studia ofiarowane Profesorowi Marianowi Zgórniakowi (pp. 41-53). Kraków: Historia Iagellonica.

Cetnarowicz, A. (2001c). Die slowenishe Nationalbewegung in den Augen der galizischen Presse in der ersten Jahren des Dualismus (1867-1870). In V. Rajšp, R. Bertož, J. Cvirn, W. Lukan. J. Fischer \& B. Marušič (Eds.), Melikov zbornik. Slovenci v zgodovini in njihovi srednjeevropski sosedje (pp. 569-586). Ljubljana: Založba ZRC SAZU.

Cetnarowicz, A. (2001d). Odrodzenie narodowe w Dalmacji. Od "slavenstva" do nowoczesnej chorwackiej i serbskiej idei narodowej. Kraków: Wydawnictwo Uniwersytetu Jagiellońskiego.

Cetnarowicz, A. (2001e). Powstanie i działalność stronnictwa narodowego w Dalmacji w latach 1860-1866. Prace Komisji Środkowoeuropejskiej PAU, 9, 43-71.

Cetnarowicz, A. (2001f). Powstanie w Boce Kotorskiej 1869 - lokalny konflikt, czy początek ogólnego ruchu Słowian południowych. Studia Historyczne, 44(2), 313-322.

Cetnarowicz, A. (2001g). Słowenia. In Encyklopedia Historyczna Świata (Vol. 9, Part 2. Europa, pp. 183-197). Kraków: Opres.

Cetnarowicz, A. (2001h). Stosunki serbsko-chorwackie w Dalmacji w okresie odrodzenia narodowego (1860-1880). In E. Orman \& A. Cetnarowicz (Eds.), H. Wereszycki (1898-1990). Historia $w$ życiu historyka (pp. 367-378). Kraków: Historia Iagellonica.

Cetnarowicz, A. (2001i). Włoskie, węgierskie i polskie plany ekspedycji do Dalmacji w latach 1864-1866. Zeszyty Naukowe UJ. Prace Historyczne, 128, 101-109.

Cetnarowicz, A. (2002a). Die Slowenen und die anderen Südslawen in der öffentlichen Meinung der Polen im 19. Jahrhundert. In A. Moritsch \& A. Moser (Eds.), Den Anderen im Blick. Stereotype im ehemaligen Jugoslawien (pp. 141-152). Frankfurt/Main: Peter Lang.

Cetnarowicz, A. (2002b). Ruch narodowy w Dalmacji na łamach prasy galicyjskiej w latach sześćdziesiątych XIX wieku. In K. Ślusarek (Ed.), Polska i Polacy w XIX i XX wieku. Studia ofiarowane Prof. Mariuszowi Kulczykowskiemu w 70. rocznicę Jego urodzin (pp. 157-180). Kraków: Historia Iagellonica.

Cetnarowicz, A. (2003a). Odjek narodnog preporoda u Dalmaciji na stranicama galicijskog tiska (1860-1880). In A. Buczynski, M. Kruhek \& S. Matković (Eds.), Hereditas rerum Croaticarum od honorem Mirko Valentić (pp. 184-193). Zagreb: Hrvatski institut za povijest.

Cetnarowicz, A. (2003b). Polityka bałkańska Hotelu Lambert. In Z. Baran (Ed.), Czartoryscy Polska - Europa. Historia i współczesność (pp. 160-167). Kraków: DjaF.

Cetnarowicz, A. (2004). Koncepcje federalistyczne wśród Słowian południowych (do roku 1914). In K. Ślusarek (Ed.), Europa unii i federacji. Idea jedności narodów i państw od średniowiecza do czasów współczesnych (pp. 259-272). Kraków: Historia Iagellonica. 
Cetnarowicz, A. (2005). Die polnische Beitrag in der Gestaltung der Einheitsidee bei den Südslawen. In K. Sládek \& D. Škvarna (Eds.), Hl'adanie novej podoby strednej Európy (fenomén integrácie a dezintegrácie od osvietenstva po 1. svetovú vojnu) (pp. 88-97). Bratislava: Vydavatel'stvo Michala Vaška v Prešove pre Centrum pre európsku politiku Bratislava.

Cetnarowicz, A. (2006a). Kwestia wyznaniowa w procesie kształtowania się chorwackiej i serbskiej idei narodowej w Dalmacji w XIX wieku. In D. Quirini-Popławska (Ed.), Portolana. Studia Mediterranea (Vol. 2. Religie świata śródziemnomorskiego, pp. 259-269). Kraków: Wydawnictwo Uniwersytetu Jagiellońskiego.

Cetnarowicz, A. (2006b). Narodni preporod u Dalmaciji. Od "slavenstva" prema modernoj hrvatskoj i srpskoj narodnoj ideji. Zagreb: Srednja Europa.

Cetnarowicz, A. (2006c). Odrodzenie narodowe w Istrii w latach 1860-1907 - zarys problematyki. In A. Patek \& W. Rojek (Eds.), Naród Państwo. Europa Środkowa w XIX i XX wieku. Studia ofiarowane Michałowi Pułaskiemu w pięćdziesięciolecie pracy naukowej (pp. 35-44). Kraków: Wydawnictwo Uniwersytetu Jagiellońskiego.

Cetnarowicz, A. (2006d). Udział polskiej emigracji w kryzysie serbskim na początku lat 40-tych XIX wieku. In P. Bunjak (Ed.), 110 godina polonistike u Srbiji (pp. 267-275). Beograd: Slavističko društvo Srbije.

Cetnarowicz, A. (2007a). Die Entwicklung der modernen kroatischen und serbischen Nationalidee in Dalmatien in der zweiten Hälfte des 19. Jahrhunderts. Ein Beitrag zur Diskussion über die Entstehung von Nationalitäten. In E. Brix, A. Suppan \& E. Vyslonzil (Eds.), Südosteuropa. Traditionen als Macht (pp. 51-64). Wien: Oldenbourg Wissenschaftsverlag.

Cetnarowicz, A. (2007b). Polsko-słoweńskie związki polityczne w XIX wieku. In J. Purchla (Ed.), Kraków-Lublana a mit Europy Środkowej (pp. 123-138). Kraków: MCK.

Cetnarowicz, A. (2007c). Sprawa statusu Dalmacji w latach 1865-1868 - niewykorzystana szansa Węgier. In A. Cetnarowicz \& S. Pijaj (Eds.), Węgry i dookoła Węgier... Narody Europy Środkowej w walce o wolność i tożsamość w XIX i XX wieku. Materiaty z konferencji dotyczacej problematyki narodowościowej w Europie Środkowej zorganizowanej z okazji 10 rocznicy śmierci Prof. Wacława Felczaka (Kraków 12-13 XII 2003) (pp. 123-136). Kraków: Historia Iagellonica.

Cetnarowicz, A. (2008a). Die Nationalbewegung in Dalmatien im 19. Jahrhundert. Von "Slaventum" bis zur modernen kroatischen und serbischen Nationalidee. Frankfurt/Main: Peter Lang Verlag.

Cetnarowicz, A. (2008b). Mosty i przepaście. Kształtowanie się świadomości narodowej i idei jedności wśród Słowian południowych w XIX wieku. In P. Żurek (Ed.), Tantum Historiae. Ksiega ofiarowana profesorowi Mieczysławowi Tantemu w osiemdziesiąta rocznicę urodzin (pp. 42-54). Bielsko-Biała.

Cetnarowicz, A. (2009a). "Mit Sicherheit wird man auch bei uns so vorgehen...” Die Haltung der Slowenen zur Lage der Polen in preussischen Teilungsgebiet. In E. Dmitrów \& T. Weger (Eds.), Deutschlands östlicie Nachbarschaften. Eine Sammlung von historischen Essays für Hans Henning Hahn (pp. 411-428). Fraknfurt/Main: Peter Lang.

Cetnarowicz, A. (2009b). Die Slawen der Habsburgermonarchie - Wege ihrer nationalen Emanzipation im 19. Jahrhundert. In A. Perłkowski, R. Bartczak \& A. Schindling (Eds.), Reiche Mitteleuropas in der Neuzeit. Integration und Herrschaft, Liber memorabilis Jan Pirożyński (pp. 261-270). Kraków: Księgarnia Akademicka. 
Cetnarowicz, A. (2009c). Religion und Südslawische Nation. Die Konfessionelle Frage und die Formierung der modernen kroatischen und serbischen Nationalidee in Dalmatien im 19. Jahrhundert. Historishes Jahrbuch, 129, 461-477.

Cetnarowicz, A. (2009d). The Forging of Modern National Identity. Slavic Nations in the Habsburg Monarchy in the 19th Century. In J. Kłoczowski \& H. Łaszkiewicz (Eds.), East-Central Europe in European History. Themes and Debates (pp. 255-270). Lublin: The Institute of East-Central Europe.

Cetnarowicz, A. (2009e). Živio i evviva! Początki sporu o tożsamość Istrii w XIX wieku. In D. Quirini-Popławska (Ed.), Portolana, Studia Mediterranea (Vol. 4. Mare inclitum. Oddziaływanie cywilizacji śródziemnomorskiej, pp. 269-280). Kraków: Wydawnictwo Uniwersytetu Jagiellońskiego.

Cetnarowicz, A. (2010a). Hrvatski i slovenski narodni pokret u Istri u razdoblju jačanja taljanskog iredentizma u prvih godinama dualizma. Hisorijski zbornik, 63(2), 437-454.

Cetnarowicz, A. (2010b). Odrodzenie narodowe w Istrii w latach 1860-1907. Kraków: Historia Iagellonica.

Cetnarowicz, A. (2011a). Dalmatinski narodnjaci o Sječanskom ustanku u Polskoj 1863. godine. In I. Ivelić (Ed.), Zbornik Nikše Stančića (pp. 151-163). Zagreb: Filozofski fakultet Sveučilišta u Zagrebu, Odsjek za povijest - FF press.

Cetnarowicz, A. (2011b). Vom "Slawentum” zur modernen kroatischen und serbischen Nationalidee. Ein Beitrag zur kroatisch-serbischen Beziehungen in Dalmatien während der nationalen "Wiedergeburt” in den Jahren 1860-1880. In I. Breneselović (Ed.), Spomenica Baltazara Bogišića o stogodišnjici njegove smrti 24. aprila 2005 godine (Vol. 1. pp. 39-50). Beograd: Službeni glasnik - Institut za uporedno pravo.

Cetnarowicz, A. (2011c). Życie polityczne w Galicji z perspektywy słoweńskiego i chorwackiego ruchu narodowego. In A. Kawalec, W. Wierzbieniec \& I. Zaszkliniak (Eds.), Galicja 1772-1918. Problemy metodologiczne, stan i potrzeby badań (Vol. 1. pp. 325-336). Rzeszów: Wydawnictwo Uniwersytetu Rzeszowskiego.

Cetnarowicz, A. (2012). I movimenti nazionali degli Slavi del Sud nel periodo del Risorgimento. In F. Leoncini (Ed.), L'alba dell'Europa liberale. La trama internazionale delle cospirazioni risorgimentali (pp. 75-85). Rovigo: Ass. Culturale Minelliana.

Cetnarowicz, A. (2013a). "Pisane sercem węgierskim a duszą słowiańską...” Węgrzy, Polacy i Słowianie południowi w twórczości naukowej Wacława Felczaka. In W. Felczak (Ed.), Europa Centralis (pp. IX-XXV). Kraków: Avalon.

Cetnarowicz, A. (2013b). Chorwacki ruch narodowy w Dalmacji wobec powstania styczniowego. In T. Kargol (Ed.), Powstanie styczniowe - odniesienia, interpretacje, pamięć (pp. 37-50). Kraków: Historia Iagellonica.

Cetnarowicz, A. (2013c). Historiografia dziewiętnastowiecznych dziejów krajów słowiańskich w okresie przełomu i w ostatnim piętnastoleciu. In K. Makowski \& M. Saczyńska (Eds.), Słowianie - idea i rzeczywistość. Zbiór studiów (pp. 131-150). Poznań: IH UAM.

Cetnarowicz, A. (2014a). Aspiracje i programy narodowe Słowian południowych w monarchii habsburskiej w XIX wieku. In M. Koźmiński (Ed.), Cywilizacja europejska - różnorodność i podział (Vol. 3. pp. 277-296). Kraków: Universitas.

Cetnarowicz, A. (2014b). Narodni preporod u Istri (1860-1907). Zagreb: Srednja Europa. 
Cetnarowicz, A. (2015a). Stosunki polsko-ukraińskie i polsko-rosyjskie w opinii słoweńskiej w II połowie XIX wieku. Acta historia Neosoliensia. Vedecký časopis pre historicke vedý, 18, 161-179.

Cetnarowicz, A. (2015b). Walka o szkolnictwo narodowe w Istrii w drugiej połowie XIX wieku i sprawa utworzenia chorwackiego gimnazjum w Pazinie. In T. Pudłocki \& K. Stopka (Eds.), Amico socio et viro docto. Ksiegga ku czci Prof. Andrzeja Banacha (pp. 55-71). Kraków: Historia Iagellonica.

Cetnarowicz, A. (2016a). Pod berłem Habsburgów. Polsko-słoweńskie stosunki polityczne w drugiej połowie XIX wieku. In A. Cetnarowicz, D. Nećak, S. Pijaj \& B. Todorović (Eds.), $W$ Galicji i nad Soczą. Polacy i Słoweńcy na frontach i wojny światowej / V Galiciji in ob Soči. Poljaki in Slovenci na frontah I svetovne vojne (pp. 13-23). Kraków: Historia Iagellonica.

Cetnarowicz, A. (2016b). Pod žezlom Habsburžanov. Poljsko-slovenski politični odnosi v 2. polovici 19. stoletja. In A. Cetnarowicz, D. Nećak, S. Pijaj \& B. Todorović (Eds.), W Galicji $i$ nad Socza. Polacy i Słoweńcy na frontach i wojny światowej / V Galiciji in ob Soči. Poljaki in Slovenci na frontah I svetovne vojne (pp. 123-132). Kraków: Historia Iagellonica.

Cetnarowicz, A. (2016c). Problematyka słowiańska w twórczości Mirosława Frančicia. In J. Lencznarowicz, J. Pezda \& A. A. Zięba (Eds.), Polacy i świat, kultura i zmiana. Studia historyczne i antropologiczne ofiarowane Profesor Halinie Florkowskiej-Frančić (pp. 505510). Kraków: Księgarnia Akademicka.

Cetnarowicz, A. (2016d). Procesy kształtowania się nowoczesnych narodów w Europie Środkowej a Polacy. In A. Cetnarowicz \& S. Pijaj (Eds.), Polacy i ich sasiedzi w Europie Środkowej. Związki polityczne i ich odbicie w historiografii (pp. 27-44). Kraków: DiG.

Cetnarowicz, A. (2017a). Kastavština u narodnom preporodu u Istri - usponi te sumnje i okljevanja. Zbornik Kastavštine, 21, 65-77.

Cetnarowicz, A. (2017b). Tajna diplomacija Adama Ježija Čartoriskog na Balkanu. Hotel Lambert i srpska kriza 1840-1844. Beograd: Slavističko društvo Srbije.

Cetnarowicz, A. (2018). Parlamentarna działalność Stefana Mitrova Ljubišy na forum Rady Państwa w Wiedniu. In Ł. Burkiewicz, R. Hryszko, W. Mruk \& P. Wróbel (Eds.), Polonia. Italia. Mediterraneum. Studia ofiarowane Pani Profesor Danucie Quirini-Popławskiej (pp. 375-386). Kraków: Historia Jagellonica.

Chimiak, Ł. (2013). Z dziejów polskiej mniejszości w Bośni. Życie i działalność Wiktora i Artura Burdów. Studia z Dziejów Rosji i Europy Środkowo-Wschodniej, 48(1), 55-74.

Czamańska, I., \& Szulc, W. (2002). Pojęcie Macedonii i Macedończyków w ciągu wieków. In B. Zieliński (Ed.), Wokół Macedonii: siła kultury - kultura siły (pp. 21-33). Poznań: Wydawnictwo Naukowe Uniwersytetu im. Adama Mickiewicza.

Czapik-Lityńska, B. (2007). Problem chorwackiej tożsamości narodowej na tle integracyjnego utopizmu grupy iliryjskiej. Południowosłowiańskie Zeszyty Naukowe, 4, 43-49.

Czapik-Lityńska, B., \& Tokarz, E. (Eds.). (1992). Kryzys tożsamości, Katowice: Uniwersytet Śląski.

Czerwiński, M. (2005). Elementy dyskusyjnej konstrukcji chorwackiej tożsamości narodowej. Prace Komisji Środkowoeuropejskiej PAU, 13, 7-27.

Czerwiński, M. (2007a). Lik i ideja Josipa Juraja Strossmayera u diskusijama suvremene hrvatske historiografie. In M. Dąbrowska-Partyka \& M. Czerwiński (Eds.), Josip Juraj Strossmayer. Hrvatska, ekumenizam, Europa / Chorwacja, ekumenizm, Europa (pp.73-86). Kraków: Scriptum. 
Czerwiński, M. (2007b). Semiotyka dyskursu historycznego. Chorwackie i serbskie syntezy dziejów narodu. Kraków: Wydawnictwo Uniwersytetu Jagiellońskiego.

Czerwiński, M. (2011). “Jak Kraków Zagrzebiowi...” Historia relacji polsko-chorwackich w kontekście albumu wydanego w roku 1881 / Kao Krakov Zagrebu. Povijest poljsko-hrvatskih odnosa u kontekstu albuma izdanog 1881. godine. In M. Czerwiński \& M. Najbar-Agičić (Eds.), Kraków Zagrzebiowi, reprint z roku 1881 (pp. 7-31). Zagreb: Srednja Europa.

Czerwiński, M. (2012). Semiotyka dyskursu historycznego. Serbskie i chorwackie syntezy historyczne. Kraków: Wydawnictwo Uniwersytetu Jagiellońskiego.

Czerwiński, M. (2014a). Narracje i encyklopedie. Wyobrażenia historyczne Chorwatów i Serbów. Rocznik Antropologii Historii, 1/6, 93-118.

Czerwiński, M. (2014b). Znaki integracji - uniwersum władzy symboli chorwackiego iliryzmu (na marginesie dyskusji o chorwackości odrodzenia narodowego). In M. Dyras, B. Suchoń-Chmiel \& T. Kusek (Eds.), Symbole władzy - władza symboli (pp. 204-228). Kraków: Scriptum.

Czerwiński, M., \& Agičić, D. (Eds.). (2016). Poljsko-hrvatske veze kroz stoljeća. Povijest, kultura, književnost. Zbornik radova sa znanstvenog skupa / Związki polsko-chorwackie na przestrzeni wieków. Historia, kultura, literatura. Zagreb: Srednja Europa.

Darasz, Z. (1995). Problemy autoidentyfikacji kulturowej i narodowej w literaturze słoweńskiej. Katowice: Uniwersytet Śląski.

Darasz, Z. (1996). Impulsy germańsko-romańskie a historyczna promocja literatury słoweńskiej. In M. Bobrownicka (Ed.), Symbioza kultur słowiańskich i niesłowiańskich w Europie Środkowej (pp. 99-108). Kraków: Universitas.

Darasz, Z. (1997a). Niektóre aspekty słoweńskiego dialogu z tradycją narodowej kultury. In M. Bobrownicka, L. Suchanek \& F. Ziejka (Eds.), Współcześni Słowianie wobec własnych tradycji i mitów. Sympozjum w Castel Gandolfo w dniach 19-20 maja 1996 (pp. 77-85). Kraków: Universitas.

Darasz, Z. (1997b). Słoweńcy wobec iliryjskiej utopii. In B. Czapik-Lityńska (Ed.), Utopia $w$ językach i literaturach Słowian (Vol.2. Z przemian świadomości utopijnej w procesie historycznoliterackim, pp. 78-80). Katowice: Wydawnictwo Uniwersytetu Śląskiego.

Darasz, Z. (2004). Słowiańskie identyfikacje słoweńskiej kultury narodowej. Południowosłowiańskie Zeszyty Naukowe, 1, 97-107.

Darasz, Z. (2007a). Literackie portrety Lublany - dawne i nowe, własne i obce. In J. Purchla (Ed.), Kraków-Lublana a mit Europy Środkowej (pp. 109-121). Kraków: MCK.

Darasz, Z. (2007b). Słowiański wymiar słoweńskości w pismach Janeza Trdiny. Południowosłowiańskie Zeszyty Naukowe, 4, 7-17.

Darasz, Z. (2008). Rijeka w autobiografii słoweńskiego pisarza i etnologa Janeza Trdiny (1830-1905). In M. Bogusławska \& G. Szwat-Gyłybowa (Eds.), Bunt tradycji - tradycja buntu, Ksiega dedykowana Prof. K. Wrocławskiemu (pp. 221-228). Warszawa: Instytut Slawistyki Zachodniej i Południowej Wydziału Polonistyki UW.

Darasz, Z. (2017). Słoweńska literatura i sztuka w “Świecie Słowiańskim”. In J. Pezda \& S. Pijaj (Eds.), Europa Środkowa Bałkany i Polacy. Studia ofiarowane profesorowi Antoniemu Cetnarowiczowi (pp. 429-439). Kraków: Historia Iagellonica.

Dąbrowska-Partyka, M. (2003). Świadectwa i mistyfikacje. Przed i po Jugosławii. Kraków: Wydawnictwo UJ. 
Dąbrowska-Partyka, M. (2007). Rola Serbów węgierskich w procesie kształtowania się nowoczesnej tożsamości serbskiej. In A. Cetnarowicz \& S. Pijaj (Eds.), Wegry i dookoła Wegier... Narody Europy Środkowej w walce o wolność i tożsamość w XIX i XX wieku. Materiały z konferencji dotyczącej problematyki narodowościowej w Europie Środkowej zorganizowanej z okazji 10 rocznicy śmierci Prof. Wacława Felczaka (Kraków 12-13 XII 2003) (pp. 69-84). Kraków: Historia Iagellonica.

Dąbrowska-Partyka, M. (Ed.) (2005). W poszukiwaniu nowego kanonu. Reinterpretacje tradycji kulturalnej w krajach postjugosłowiańskich po 1995 roku. Kraków: Wydawnictwo Uniwersytetu Jagiellońskiego.

Dmowski, D. (1992). Stosunek Chorwatów do idei przebudowy monarchii habsburskiej w państwo dualistyczne Austro-Węgry. Przegląd Zachodnio-Pomorski, 11, 61-82.

Dmowski, D. (1995). Rozwój ruchu narodowego w Dalmacji w latach 1860-1878. Szczecińskie Studia Historyczne, 9, 35-48.

Dmowski, D. (2000). Rozwój idei jugosłowiańskiej na ziemiach chorwackich na początku XX wieku w kontekście stosunków węgiersko-chorwackich do końca I wojny światowej. Studia z Dziejów Rosji i Europy Środkowo-Wschodniej, 35, 5-23.

Drljača, D. (1997). Między Bośnią, Bukowina, Serbia i Polską. Studia i szkice etnologiczne. Wrocław: Polskie Towarzystwo Ludoznawcze.

Dymarski, M. (2010a). Konflikty na Bałkanach w okresie kształtowania się państw narodowych w XIX i na początku XX wieku. Wrocław: Wydawnictwo Uniwersytetu Wrocławskiego.

Dymarski, M. (2010b). Kształtowanie się systemu politycznego w Serbii i Bułgarii w XIX i pierwszych latach XX wieku. Prace Komisji Środkowoeuropejskiej PAU, 8, 25-57.

Dymarski, M. (2017a). Macedończyk-Macedończycy w dokumentach dyplomatycznych Królestwa Serbii 1903-1914. Slavica Wratislaviensia, 165, 101-111.

Dymarski, M. (2017b). Stosunki etniczne w Czarnogórze: aspekt historyczny i współczesny. Studia Środkowoeuropejskie i Bałkanistyczne, 25, 207-227.

Dyras, M. (2002a). Chorwackie ucieczki z Bałkanów. Pamiętnik Słowiański, 52(1), 51-56.

Dyras, M. (2002b). Strategie odzyskiwania utraconej tożsamości. Chorwacka "opowieśc”" o historii. In B. Zieliński (Ed.), Narodowy i ponadnarodowy model kultury. Europa Środkowa i Półwysep Bałkański (pp. 113-119). Poznań: Wydawnictwo Naukowe Uniwersytetu Adama Mickiewicza.

Dyras, M. (2002c). Strategie odzyskiwania utraconej tożsamości. Chorwacka "powieść o historii”. In B. Zieliński (Ed.), Narodowy i ponadnarodowy model kultury. Europa Środkowa i Półwysep Bałkański (pp. 113-119). Poznań: Wydawnictwo Naukowe UAM.

Dyras, M. (2004). Wizje przeszłości w chorwackich podręcznikach historii w latach 90-tych XX wieku. Prace Komisji Środkowoeuropejskiej PAU, 12, 165-170.

Dyras, M. (2007). Kilka uwag o chorwackiej etnogenezie i manipulacjach narodową tożsamością. In J. Axer \& J. Olko (Eds.), Dawne kultury w ideologiach XIX i XX wieku (pp. 77-87). Warszawa: DiG.

Dyras, M. (2009a). Re-inkarnacje narodu. Chorwackie narracje tożsamościowe w latach dziewięćdziesiątych XX wieku. Kraków: Wydawnictwo Uniwersytetu Jagiellońskiego.

Dyras, M. (2009b). Zależność od historii jako czynnik świadomości narodowej. In M. Dąbrowska-Partyka (Ed.), Kultury słowiańskie między postkomunizmem a postmodernizmem (pp. 63-74). Kraków: Wydawnictwo UJ. 
Dyras, M. (2015). Autostereotypy i jak widzą Chorwatów inni. In R. Kusek, J. Purchla \& J. Santera-Szeligi (Eds.), Narody i stereotypy 25 lat później. Nowe granice, nowe horyzonty (pp. 268-281). Kraków: MCK.

Dziadzio, A. (2017). Władza na pograniczach monarchii habsburskiej doby konstytucyjnej wobec niechrześcijańskich mniejszości religijnych. In D. Szpoper \& P. Dąbrowski (Eds.), Pogranicza w historii prawa i myśli polityczno-prawnej: praca zbiorowa (pp. 131-147). Gdańsk-Olsztyn: Wydawnictwo Gdańskiej Szkoły Wyższej.

Dziekan, M. (2011). Islam na Bałkanach w relacji z podróży po Bośni i Hercegowinie ks. Marcina Czermińskiego SJ (1860-1931). Południowosłowiańskie Zeszyty Naukowe. Język Literatura - Kultura, 8, 133-163.

Falski, M. (2004). Dubrownik w chorwackiej przestrzeni kulturowej z perspektywy XIX stulecia. In J. Goszczyńska (Ed.), Problemy tożsamości kulturowej w krajach słowiańskich, 2: Jej formy i przemiany (pp. 35-61). Warszawa: Uniwersytet Warszawski, Instytut Filologii Słowiańskiej.

Falski, M. (2007). Pamięć społeczna a ideologia: z problematyki autodefinicji kultury bośniackiej. Południowosłowiańskie Zeszyty Naukowe. Język - Literatura - Kultura, 4, 51-64.

Falski, M. (2008a). Czym jest "kneži kamen”? Szkic o słoweńskiej polityce symboli. Pamiętnik Słowiański, 58(1), 49-65.

Falski, M. (2008b). Porzadkowanie przestrzeni narodowej-przypadek chorwacki. Studium z historii wyobrażeń kulturowych. Warszawa: Wydział Polonistyki Uniwersytetu Warszawskiego.

Falski, M. (2013). Croatian Political Discourse in 1861 and the Main Forms of Public Debate in the Nineteenth Century. Acta Poloniae Historica, 108, 71-92.

Falski, M. (2017). Pierwsza mapa Słowenii. Poznańskie Studia Slawistyczne, 13, 317-334, DOI: https://doi.org/10.14746/pss.2017.13.19

Faszcza, D. (2018). Wojna serbsko-bułgarska 1885 roku. Studium polityczno-wojskowe. Oświęcim: Napoleon V.

Felczak, W. (1963). Słowianie węgierscy wobec sprawy rewolucji węgierskiej i kontrrewolucji w 1848 r. Przeglad Historyczny, 54(4), 572-591.

Felczak, W. (1968). Tajna polityka chorwacka w 1867 r. w świetle nieznanych dokumentów. Studia Historyczne, 11(3), 343-365.

Felczak, W. (1969). Ugoda węiersko-chorwacka 1868 roku. Wrocław: Ossolineum.

Felczak, W., \& Wasilewski, T. (1985). Historia Jugosławii. Warszawa: Ossolineum.

Filcek, K. (2011). Tożsamość Bośniaków a procesy polityczne w Bośni i Hercegowinie. Społeczeństwo i Polityka, 1, 117-153.

Gibas-Krzak, D. (2009). Serbsko-albański spór o Kosowo w XX wieku. Uwarunkowania - Przebieg - Konsekwencje. Toruń: Wydawnictwo Adam Marszałek.

Gibas-Krzak, D. (2015). Zmierzch panowania tureckiego na Bałkanach: polityczne, społeczno-kulturowe i militarne uwarunkowania schyłku władania Bośnią i Hercegowiną przez Osmanów. Balcanica Posnaniensia. Acta et studia, 22(2), 15-36.

Gibas-Krzak, D. (2016). Bośnia i Hercegowina: determinanty dziejów. Pomiędzy Serbami, Chorwatami a supremacją Muzułmanów. Częstochowa: Wydawnictwo im. Stanisława Podobińskiego Akademii im. Jana Długosza. 
Gil, D. (1995a). Hymnografia serbska i jej rola w kulturze narodowej. Studia nad "Srbljakiem". Kraków: Wydawnictwo Uniwersytetu Jagiellońskiego.

Gil, D. (1995b). Literatura staroserbska w służbie ideologii narodowej. Zeszyty Naukowe UJ. Prace Historycznoliterackie, 90, 43-47.

Gil, D. (2002). Chorwacki biskup Josip Juraj Strossmayer i serbski biskup Mihailo wobec dziewiętnastowiecznej idei narodowej i religijnej. Pamiętnik Słowiański, 52, 47-56.

Gil, D. (2005a). Historia jako fatum. Dzieje narodu i państwa według współczesnych historiografii serbskich. Slavia Meridionalis, 5, 11-30.

Gil, D. (2005b). Kryzys tożsamości. Serbska Cerkiew Prawosławna wobec przemian polityczno-społecznych po 5 X 2000 r. In M. Dąbrowska-Partyka (Ed.), W poszukiwaniu nowego kanonu. Re-interpretacje tradycji kulturalnej w państwach postjugosłowiańskich po 1995 roku (pp. 267-293). Kraków: Wydawnictwo Uniwersytetu Jagiellońskiego.

Gil, D. (2005c). Prawosławie. Historia. Naród. Miejsce kultury duchowej w serbskiej tradycji i współczesności. Kraków: Wydawnictwo Uniwersytetu Jagiellońskiego.

Gil, D. (2007). Serbscy Boszniacy (Bošnjaci): pomiędzy fundamentalizmem a dialogiem międzyreligijnym prawosławnych i muzułmanów w Sandžaku). Prace Komisji Kultury Stowian PAU, 6, 197-223.

Gil, D. (2013). Państwo - Naród - Kościół i specyfika serbskiej religijno-narodowej koncepcji diarchii. In B. Zieliński (Ed.), Język, literatura i kultura Słowian - dawniej i dziś (Vol. 3. Litteraria, pp. 49-63). Poznań: UAM.

Gil, D. (2017). Ewolucja i funkcje narodu w Serbii od schyłku XVIII wieku. Slavia Meridionalis, 17, DOI: https://doi.org/10.11649/sm.1325

Gil, D. (2018) Narod u istoriozofskim koncepcijama: srpsko-crnogorski katalog ideja. In B. Zieliński (Ed.), Literaturoznawstwo, kulturoznawstwo, folklorystyka: prace na XVI Międzynarodowy Kongres Slawistów w Belgradzie 2018 (pp. 53-61). Poznań: Wydawnictwo Naukowe UAM.

Giza, A. (1988). Oświata w Serbii w latach 1829-1914. Rozprawy z dziejów oświaty, 31, 107-125.

Giza, A. (1990a). Idea jugosłowiańska. Kamena, 3, 37-39.

Giza, A. (1990b). Udział Polaków w powstaniu serbskiego dokumentu państwowego "Načertanija”. Ze skarbca kultury, 50, 135-154.

Giza, A. (1992). Idea jugoslawizmu w latach 1800-1918. Szczecin: Uniwersytet Szczeciński.

Giza, A. (1993a). Austroslawizm w XIX wieku. Przegląd Zachodnio-Pomorski, 1, 109-120.

Giza, A. (1993b). Austroslawizm. Kamena, 3/4, 27-43.

Giza, A. (1994). Narodziny i rozpad Jugosławii. Szczecin: Wydawnictwo Naukowe Uniwersytetu Szczecińskiego.

Giza, A. (1996). Ziemie macedońskie na przełomie XIX i XX wieku. Szczecin: Wydawnictwo Naukowe US 1996.

Giza, A. (1997). Polskie aspekty jugoslawizmu w latach 1848-1875. Szczecińskie Studia Historyczne, 7, 17-33.

Giza, A. (1998a). Liceum i Wielka Szkoła w Belgradzie oraz ich znaczenie dla rozwoju świadomości narodowej Serbów w XIX wieku. Ze skarbca kultury, 47, 163-178. 
Giza, A. (1998b). Państwa bałkańskie wobec kwestii macedońskiej w latach 1878-1918. Szczecin: Wydawnictwa Naukowe US.

Giza, A. (1998c). Powstanie ilindeńskie 1903 roku w Macedonii, Part 1. Szczecińskie Studia Historyczne, 11, 135-115.

Giza, A. (1998d). Sytuacja polityczno-gospodarcza na ziemiach macedońskich pod koniec XIX wieku. In A. Giza (Ed.), Rosja - Polska - Bałkany w XVIII-XX wieku (pp. 187-210). Szczecin: Wydawnictwo Naukowe US.

Giza, A. (2001a). Inteligencja chorwacka w ruchu iliryjskim. Studia Historyczne, 44(3), 405-422.

Giza, A. (2001b). Stosunki narodowościowe na ziemiach macedońskich w początkach XX wieku. Balcanica Posnaniensia. Acta et studia, 11/12, 129-135.

Giza, A. (2001c). Tendencje polityczne Chorwacji na przełomie XIX i XX wieku. In Przemiany społeczno-polityczne na Pomorzu Środkowym w latach 1945-1956. Materiały z konferencji (pp. 185-201). Koszalin: Koszalińska Biblioteka Publiczna im. J. Lelewela.

Giza, A. (2001d). Wieś macedońska na przełomie XIX i XX wieku. Rocznik Historyczny Muzeum Historii Polskiego Ruchu Ludowego, 14, 142-151.

Giza, A. (2001e). Życie polityczne Chorwatów pod koniec XIX wieku. In E. Wilgocki (Ed.), Instantia est mater doctrinae - księga jubileuszowa Prof. Władysława Filipiaka (pp. 399417). Szczecin: Stowarzyszenie Naukowe Archeologów Polskich Oddział w Szczecinie.

Giza, A. (2002a). Bośnia i Hercegowina w dobie tureckiego i austriackiego panowania (1800-1914). Szczecin: Wydawnictwo Naukowe US.

Giza, A. (2002b). Bośnia i Hercegowina w dobie wielkiego kryzysu bałkańskiego w latach 1875-1878. Studia Historyczne, 1, 17-39.

Giza, A. (2002c). Od aneksji Bośni i Hercegowiny do zamachu w Sarajewie. Szkice Podlaskie, $10,53-74$.

Giza, A. (2002d). Ziemie chorwackie w połowie XIX wieku. In A. Czubiński, B. Lapis \& Cz. Łuczak (Eds.), Społeczeństwo, armia i polityka w dziejach Polski i Europy. Studia z dziejów politycznych $i$ wojskowych dedykowane profesorowi Benonowi Miśkiewiczowi z okazji jubileuszu siedemdziesięciolecia urodzin (pp. 395-413). Poznań: Instytut Historii UAM.

Giza, A. (2003). Bułgaria i problem macedoński od początku XVIII do lat trzydziestych XX wieku. Szczecin: Wydawnictwo Naukowe Uniwersytetu Szczecińskiego.

Goszczyńska, J. (Ed.). (2005). Problemy tożsamości kulturowej w krajach słowiańskich 3. Warszawa: Uniwersytet Warszawski, Instytut Filologii Słowiańskiej.

Gregorczyk, D. (2007). Misje księdza Marcina Czermińskiego SJ do Polonii bośniackiej w latach 1898-1909. Studia Bobolanum, 3, 47-64.

Gregorczyk, D. (2010). Polityczne i militarne aspekty wojny Turcji z Serbią i Czarnogórą w latach 1876-1878. In R. Jankowska (Ed.), Turecka droga do Unii Europejskiej (pp. 85-102). Katowice: Rada Samorządu Studenckiego Międzynarodowej Szkoły Nauk Politycznych Uniwersytetu Śląskiego.

Gregorczyk, D. (2010). Polscy urzędnicy w administracji Bośni i Hercegowiny w latach 18791914. Roczniki Administracji i Prawa, 10, 83-98.

Gregorczyk, D. (2011). Emigracja polska w Bośni na przełomie XIX i XX wieku - problemy w sferze językowej i oświatowej. In R. Jankowska \& B. Nowosad (Eds.), Polityki językowe: 
wielojęzyczność i wielojęzykowość w Europie (pp. 113-130). Katowice: Rada Samorządu Studenckiego Międzynarodowej Szkoły Nauk Politycznych Uniwersytetu Śląskiego.

Gregorczyk, D. (2012). Aspekty polityczne i militarne udziału Polaków w działaniach zbrojnych na obszarze Bośni i Hercegowiny od II połowy XIX wieku do czasów współczesnych. In A. Barcik, R. Jankowska \& G. Libor (Eds.), Europejska Polityka Sąsiedztwa w regionie śródziemnomorskim (pp.63-85). Bielsko-Biała: Wydawnictwo Naukowe Akademii Techniczno-Humanistycznej.

Grela, J. (1996). Krytyka idei neoslawizmu na łamach petersburskiego czasopisma "Votum separatum" (rok 1908). Acta UAM, 1, 169-181.

Halili, R. (2002). Idea albańskiego odrodzenia narodowego i jego stosunek do Macedonii (1878-1912). In B. Zieliński (Ed.), Wokół Macedonii: siła kultury - kultura siły (pp. 189-206). Poznań: Wydawnictwo Naukowe Uniwersytetu im. Adama Mickiewicza.

Hedba, W. (2012). Kształtowanie się państwowości Czarnogóry. Politeja, 1, 359-388.

Jagiełło-Szostak, A. (2015). Społeczno-polityczne aspekty tożsamości narodowej Boszniaków z Sandżaku. Wschodnioznawstwo, 2005, 305-319.

Jakóbiec-Semkowowa, M. (2016a). Bałkański tygiel kultur i konfesji w dziewiętnastowiecznych relacjach polskich podróżników. Slavica Wratislaviensia, 162, 7-23.

Jakóbiec-Semkowowa, M. (2016b). Bałkański tygiel kultur i konfesji z polskiej perspektywy widziany (XIX-XXI wiek). In E. Dobierzewska-Mozrzymas \& A. Jezierski (Eds.), Nauka w służbie człowiekowi (pp. 143-150). Wrocław: ATUT.

Janusz, J. (2017). Galicja, Bośnia i Hercegowina: wspomnienia. Brzezia Łąka: Wydawnictwo Poligraf.

Kale, S. (2014). Chorwackie echa walki Polaków o wolność. Powstanie styczniowe w chorwackiej opinii publicznej. Studia z Dziejów Rosji i Europy Środkowo-Wschodniej, 69(1), 29-41.

Kale, S., \& Brlić, I. (2017). Podróż Bronisława Grabowskiego do Chorwacji i Slawonii w 1882 roku w świetle korespondencji administracji chorwackiej. In J. Pezda \& S. Pijaj (Eds.), Europa Środkowa Bałkany i Polacy. Studia ofiarowane profesorowi Antoniemu Cetnarowiczowi (pp. 395-406). Kraków: Historia Iagellonica.

Kaniecka, D. (2014). Opowiedzieć naród. Chorwackość według Augusta Šenoi. Kraków: Wydawnictwo Uniwersytetu Jagiellońskiego.

Karolczak, K. (2017). W oczach polskich arystokratów... Opatija w końcu XIX wieku. In J. Pezda \& S. Pijaj (Eds.), Europa Środkowa Bałkany i Polacy. Studia ofiarowane profesorowi Antoniemu Cetnarowiczowi (pp. 441-445). Kraków: Historia Iagellonica.

Kawka, M., \& Płaneta, P. (2013). Dyskursy o Macedonii. Kraków: Wydawnictwo UJ.

Kawka, M., \& Stawowy-Kawka, I. (Eds.). (2008). Tożsamość narodowa w społeczeństwie multietnicznym Macedonii: historia, kultura, literatura, język, media. Kraków: Wydawnictwo Uniwersytetu Jagiellońskiego.

Kilias, J. (2000). Miroslava Hrocha dociekania i dyskusje dotyczące genezy nowoczesnych narodów. Przeglą Historyczny, 1, 109-129.

Klejn, Z. (2005). Walka o wolność Macedonii a Polacy. In I. Stawowy-Kawka (Ed.), Miejsce Macedonii na Bałkanach: historia, polityka, kultura, nauka (pp. 279-282). Kraków: Wydawnictwo Uniwersytetu Jagiellońskiego. 
Kobylińska, A., Falski, M., \& Filipowicz, M. (2016a). Obcy czy obywatele? Słowianie a przemiany konstytucyjne w monarchii habsburskiej w latach 1860-1861. Kraków: Libron.

Kobylińska, A., Falski, M., \& Filipowicz, M. (2016b). Peryferyjność. Habsbursko-słowiańska historia nieoczywista. Kraków: Libron.

Koch, M. (2011). Ikony serbskiego romantyzmu jako bohaterowie współczesnej literatury popularnej. Polskie Studia Slawistyczne, 1, 127-144.

Kornhauser, J. (Ed.) (1999). Przemiany w świadomości i kulturze duchowej narodów Jugosławii po 1991 roku. Kraków: Wydawnictwo Uniwersytetu Jagiellońskiego.

Krajewska [z Kosmowskich], T. (1989). Pamiętnik (B. Czajecka, Ed.). Kraków: Wydawnictwo Uniwersytetu Jagiellońskiego.

Kryzia, W. (2008a). Problemy narodowościowe i językowe we wspomnieniach Josipa Vošnjaka. Południowosłowiańskie Zeszyty Naukowe, 5, 7-17.

Kryzia, W. (2008b). Słoweński, Słoweńcy i Słowenia. Zarys historii języka i kształtowania się świadomości narodowej. Kraków: Wydawnictwo Uniwersytetu Śląskiego.

Kubik, D. (2012). Słowiańszczyzna wyobrażona. Próba opisu XIX-wiecznego dyskursu slawistycznego. Pamiętnik Słowiański, 42(1-2), 5-24.

Kubik, D. (2015). Południowosłowiańska “kultura wyobrażona”. Projekt Mickiewiczowski a dziewiętnastowieczne dyskursy kulturowe w Serbii i Chorwacji. Kraków: Nomos.

Kubik, D. (2017a). Kształtowanie się idei narodu na ziemiach słoweńskich - zarys wybranych problemów. Slavia Meridionalis, 17, 1-19. DOI: https://doi.org/10.11649/sm.1340

Kubik, D. (2017b). Serbskie dziedzictwo Dubrownika w pismach Serbów dubrownickich i dalmatyńskich w XIX wieku. In D. Gil \& C. Juda (Eds.), Monologi, dialogi, polilogi w dyskursach kulturowych Słowiańszczyzny (pp. 187-204). Kraków: Scriptum.

Kwaśniak, F., \& Orlovac, A. (2013). Dzieje Polaków w Bośni 1895-1946 (J. Staszkowian, Trans.). Legnica: Biblioteka im. Jana Pawła II Wyższego Seminarium Duchownego Diecezji Legnickiej.

Lis, T. J. (2012). Wybrane przykłady lekarzy pracujących w Bośni i Hercegowinie na przełomie XIX i XX w. Archiwum Historii i Filozofii Medycyny, 75(2), 15-22.

Lis, T. J. (2013). Polityczne przyczyny kolonizacji polskiej w Bośni na przełomie XIX i XX wieku. Pamiętnik Słowiański, 63 (1/2), 151-164.

Lis, T. J. (2014a). Polskie osadnictwo i duchowieństwo w Bośni i Hercegowinie od 1894 do 1920 roku. Toruń-Nowa Ruda: Wydawnictwo Maria.

Lis, T. J. (2014b). Wkład Polaków w modernizację Bośni i Hercegowiny w okresie austro-węgierskim (1878-1918). Studia Migracyjne - Przeglad Polonijny, 40(4), 109-124.

Lis, T. J. (2015a). Osadnictwo Rusinów w Bośni i Hercegowinie na przełomie XIX i XX wieku. Studia z Dziejów Rosji i Europy Środkowo-Wschodniej, 50(1), 25-41.

Lis, T. J. (2015b). Źródła epistolarne do dziejów misji sióstr felicjanek w Bośni i Hercegowinie w latach 1903-1904. Perspectiva, 14(1), 201-214.

Lis, T. J. (2015c). Źródła narracyjne do dziejów Polonii w Bośni i Hercegowinie w okresie austro-węgierskim. Balcanica Posnaniensia. Acta et studia, 22(2), 75-89.

Lis, T. J. (2016). Iz Bosni u Poljsku. Prikaz izvornih dokumenata na temu reemigracije Poljaka iz Bosne i Hercegovine nakon II svijetskog rata. Bolesławiec: Bolesławiecki Ośrodek Kultury - Międzynarodowe Centrum Ceramiki. 
Lis, T. J., \& Maleszka, M. (Eds.). (2015). Poljska u Bosni. Bosna u Poljskoj. Kraków-Toruń-Sarajewo: Libron.

Majewski, P. (2013). (Re)konstrukcje narodu: odwieczna Macedonia powstaje w XXI wieku. Gdańsk: Wydawnictwo Naukowe Katedra.

Majewski, P. (2015). Kruševo: pomiędzy świętym miastem macedońskiego nacjonalizmu a pierwszym "etnomiastem" w Europie. Lud, 99, 161-184.

Makowski, K. (2013). Polskie badania nad dziejami Słowiańszczyzny - wprowadzenie do problemu. In K. Makowski \& M. Saczyńska (Eds.), Słowianie - idea i rzeczywistość. Zbiór studiów (pp. 7-18). Poznań: IH UAM.

Maleszka, M. (2015). Procesy akulturacji galicyjskich Żydów w Bośni: analiza teczek urzędniczych. Balcanica Posnaniensia. Acta et studia, 22(2), 91-100.

Malinowski, A. (2006). Kwestia macedońska w Bułgarii w latach 1878-1918. Toruń: Mado.

Malinowski, A. (2012a). Osmański system miletów a religijny nacjonalizm na przykładzie Kosowa. Gentes \& Nationes, 5, 69-81.

Malinowski, A. (2012b). Prasa włoska o powstaniu w Macedonii w 1903 roku. Stupskie Studia Historyczne, 18, 163-175.

Malinowski, A. (2014). Europejskie posiadłości Turcji w polityce Wielkiej Brytanii (1903-1914). Słupsk: Wydawnictwo Naukowe Akademii Pomorskiej.

Mandziuk, J. (2009). Polacy w Bośni i Hercegowinie 1878-1914. In J. Dzięgielewski (Ed.), Veritati-serviens. Ksiega pamiątkowa ojcu profesorowi Januszowi Zbudniewkowi zp. (pp. 667-681). Warszawa: Wydawnictwo UKSW.

Mikołajczak, A., Szulc, W., \& Zieliński B. (Eds.). (2004). Idee wspólnotowe Słowiańszczyzny południowej. Poznań: Wydawnictwo Naukowe UAM.

Miodońska, L. (2007). Macedonia - jej historia i język w najnowszych polskich publikacjach. Swiat i Słowo, 1, 307-319.

Miodyński, L. (2002). Granice kompetencji i granice tolerancji w badaniach macedonistycznych. In B. Zieliński (Ed.), Wokół Macedonii: siła kultury - kultura siły (pp. 75-89). Poznań: Wydawnictwo Naukowe Uniwersytetu im. Adama Mickiewicza.

Miodyński, L. (2011). Symbole miejsca w kulturze i literaturze macedońskiej. Katowice: Wydawnictwo Uniwersytetu Śląskiego.

Moroz-Grzelak, L. (2004). Aleksander Wielki a macedońska idea narodowa: słowiańskie losy postaci antycznej. Warszawa: Towarzystwo Naukowe Warszawskie, Instytut Slawistyki PAN.

Moroz-Grzelak, L. (2006). Autorytet poprzedników a tworzenie własnej tradycji w opisaniu macedońsko-słowiańskich dziejów według G. M. Pulevskiego. In B. Zieliński (Ed.), Dalecy i bliscy: materiały VII Kolokwium Polsko-Macedońskiego (pp. 163-171). Poznań: Wydawnictwo Naukowe UAM.

Moroz-Grzelak, L. (2011). Bracia Słowianie. Wizje wspólnoty a rzeczywistość. Warszawa: Slawistyczny Ośrodek Wydawniczy.

Moroz-Grzelak, L. (2015). Kręgi zainteresowań problematyką macedońską w Polsce. Publikacje naukowe. Studia z Dziejów Rosji i Europy Środkowo-Wschodniej, 50(2), 145-156.

Moroz-Grzelak, L. (2018). Słowiańszczyzna i Zachód Europy w dyskusjach intelektualistów południowosłowiańskich przełomu wieków XIX i XX: pomiędzy dialogiem a negacją. In 
B. Zieliński (Ed.), Literaturoznawstwo, kulturoznawstwo, folklorystyka: prace na XVI Międzynarodowy Kongres Slawistów w Belgradzie 2018 (pp. 177-186). Poznań: Wydawnictwo Naukowe UAM.

Muś, J. (2013). Bośnia i Hercegowina: etnopolityczne podziały i ich uwarunkowania. Lublin: Wydawnictwo KUL.

Nikolaos, M. (1993). Fałszowanie historii Macedonii: hebrajskie źródła i świadectwa o Macedonii (W. Gawłowska \& I. Szelągiewicz, Trans.). Łódź: Wydawnictwo Uniwersytetu Łódzkiego.

Nowak-Bajcar, S. (1999). Kosowo - mit i historia w konflikcie serbsko-albańskim (szkic). In E. Szczęśniak-Kajzar (Ed.), Przemiany w świadomości i kulturze duchowej narodów Jugosławii po 1991 roku (pp. 87-102). Kraków: Wydawnictwo Uniwersytetu Jagiellońskiego.

Nowak-Bajcar, S. (2010). Belgrad Simy Matavulja: przyczynek do badań nad serbskim modernizmem przełomu XIX i XX wieku. Pamiętnik Słowiański, 60(2), 83-98.

Nowak-Bajcar, S. (2012a). Sarajevo - Zagrzeb - Kraków. O miejscach opuszczonych, odrzuconych i odnalezionych na austro-węgierskiej mapie biografii Ivo Andricia. Porównania, 11(1), 193-203.

Nowak-Bajcar, S. (2012b). Mapa pamięci. Serbska proza w poszukiwaniu pamięci kulturowej. In B. Zieliński (Ed.), Topografia tożsamości (Vol. 1, pp. 163-171), Poznań: Wydawnictwo Naukowe UAM.

Nowak-Bajcar, S. (2017). Geopolityka XIX-wiecznej podróży z geopoetyką w tle: przypadek Vuka Karadžicia i Petra Preradovicia. In D. Gil \& C. Juda (Eds.), Monologi, dialogi, polilogi $w$ dyskursach kulturowych Słowiańszczyzny (pp. 205-225). Kraków: Scriptum.

Nowak-Bajcar, S. (2018a). Srpsko-poljske naučne veze u svetlu prepiske Vuka Karadžića. In B. Zieliński (Ed.), Literaturoznawstwo, kulturoznawstwo, folklorystyka: prace na XVI Międzynarodowy Kongres Slawistów w Belgradzie 2018 (pp. 205-214). Poznań: Wydawnictwo Naukowe UAM.

Nowak-Bajcar, S. (2018b). Uloga Jagielonskog sveučilišta u oblikovanju vizje poljsko-hrvatskih odnosa u svjetlu utjecaja ideja Mariana Zdziechowskiego na njegove hrvatske studente na početku XX. stoljeća. In M. Czerwiński \& D. Agičić (Eds.), Polsko-hrvatske veze kroz stoljeća. Povijest, kultura, književnost (pp. 83-92). Zagreb: Srednja Europa.

Olszewski, P. (2010). Macedonia: historia i współczesność. Radom: WSH.

Paszkiewicz, J. (2005). Włoskie interesy ekonomiczne i polityczne na ziemiach macedońskich na przełomie XIX i XX wieku. In I. Stawowy-Kawka (Ed.), Miejsce Macedonii na Bałkanach: historia, polityka, kultura, nauka (pp. 233-240). Kraków: Wydawnictwo Uniwersytetu Jagiellońskiego.

Pielech, K. (2008). Emigracja i życie Polaków w Bośni w latach 1890-1946. Boleslawiec: Proart Visual Art \& Design Studio.

Pieniążek-Marković, K. (2014). Bośnia - hortus horridus: obraz Bośni w podróżach franciszkanów Grgi Marticia i Ivana Frano Jukicia. Prace Filologiczne. Literaturoznawstwo, 4, 263-278.

Pieniążek-Marković, K. (2016). Od marzeń o wyzwoleniu po tęsknotę za utraconą arkadią: dziewiętnastowieczne relacje z podróży bośniackich franciszkanów. In J. Dziuba, M. Gustin, N. Wyszogrodzka-Liberadzka \& R. Wyżkiewicz-Maksimow (Eds.), Słowianie w podróży (Vol. 1. Język i kultura, pp. 27-40). Gdańsk: Wydawnictwo Uniwersytetu Gdańskiego. 
Pijaj, S. (1992). Wpływ ugody węgiersko-chorwackiej 1868 roku na formułowanie postulatów rezolucji sejmu galicyjskiego z 24 września 1868 roku. Rocznik Naukowo-Dydaktyczny WSP w Krakowie, 126, 79-102.

Pijaj, S. (2017). Rodzina Hristić i jej związki z Polską. In J. Pezda \& S. Pijaj (Eds.), Europa Środkowa Bałkany i Polacy. Studia ofiarowane profesorowi Antoniemu Cetnarowiczowi (pp. 293-308). Kraków: Historia Iagellonica.

Podhorodecki, L. (2000). Jugosławia: dzieje narodów, państw i rozpad federacji. Warszawa: MADA.

Potkański, W. (2011). Spór o niezależność Macedonii we współczesnej “zjednoczonej” Europie, Part 1: Okres do wybuchu II wojny światowej. Zeszyty Naukowe - Uniwersytet Szczeciński. Acta Politica, 24, 51-61.

Pudłocki, T. (2016). Franciszek Tomaszewski i njegovo putovanje po hrvatskim krajevima. Historijski zbornik, 69(2), 385-410.

Rapacka, J. (1992a). Uwagi o kształtowaniu się antyokcydentalizmu serbskiego. In T. Dąbek-Wigrowa \& A. Makowiecki (Eds.), Kategorie Europy w kulturach słowiańskich (pp. 125-132). Warszawa: Uniwersytet Warszawski, Wydział Polonistyki.

Rapacka, J. (1992b). Z dziejów mitu kosowskiego. Od Miloša Obilicia do Gavrilo Princpa. Pamiętnik Słowiański, 42, 3-14.

Rapacka, J. (1993). Rola regionalizmu w kulturze chorwackiej. In K. Handke (Ed.), Region, regionalizm - pojęcia i rzeczywistość (pp. 195-208). Warszawa: Slawistyczny Ośrodek Wydawniczy.

Rapacka, J. (1995). Godzina Herdera. O Serbach, Chorwatach i idei jugosłowiańskiej. Warszawa: Energeia.

Rapacka, J. (1996). Schyłek ideologii szlacheckich w obliczu kształtowania się ideologii narodowych w krajach Korony św. Stefana (na przykładzie chorwackim). In M. Bobrownicka (Ed.), Symbioza kultur słowiańskich i niesłowiańskich w Europie Środkowej (pp. 81-88). Kraków: Universitas.

Rapacka, J. (1997). Leksykon tradycji chorwackich. Warszawa: Slawistyczny Ośrodek Wydawniczy PAN.

Rapacka, J. (2001). X. Adam Sapieha, czyli podróż przez Chorwację polskiego słowianofila. Pamiętnik Słowiański, 51, 65-73.

Rapacka, J. (2002). Śródziemnomorze - Europa - Bałkany. Studia o literaturze południowosłowiańskiej. Kraków: Universitas.

Rapacka, J. (2003). Rzeczypospolita Dubrownicka. Sejny: Fundacja Pogranicze.

Rapacka, J. (2004). Adam Mickiewicz a romantyzm chorwacki. Pamiętnik Słowiański, 54(1), 3-11.

Rubacha, J. (2004). Bułgarski sen o Bizancjum. Polityka Bułgarii w latach 1878-1913. Warszawa: Neriton.

Rubacha, J. (2012). Bułgaria na przełomie XIX i XX wieku. Bułgarskie metamorfozy w publikacjach "Świata Słowiańskiego" (1905-1914). Olsztyn: Wydawnictwo UWM.

Rubacha, J., \& Malinowski, A. (Eds.). (2007). Historia Bułgarii 1870-1915: materiały źródłowe $z$ komentarzami. T. 2: Kwestia macedońska. Warszawa: Neriton.

Rycerska, I. (2003). Rozpad Jugosławii: przyczyny i przebieg. Kielce: Akademia Świętokrzyska. 
Seroka, M. (2011). Najszlachetniejszej krwi Chorwaci: Ante Starčević i Bośnia. Pamiętnik Słowiański, 61(1), 107-121.

Seroka, M. (2013). Chorwacja turecka - Turcja europejska? Bośnia w podróżopisarstwie epoki jugoslawizmu. Pamiętnik Słowiański, 63 (1/2), 89-113.

Skorczewski, M. (2013). Kosowo, mit kosowski i jego recepcja. Studia z Dziejów Rosji i Europy Środkowo-Wschodniej, 48, 283-292.

Skowronek, J. (1990). Kraje bałkańskie a powstanie styczniowe. In S. Kalembka (Ed.), Powstanie styczniowe 1863, Wrzenie-bój, Europa, wizje (pp. 611-636). Warszawa: PWN.

Skowronek, J. (1991). Panslavisme, slavophilie et re construction politique de l'Europe Centrale Au XIX-éme siècle. In G. Beauprêtre (Ed.), L'Europe Centrale-realité, mythé enjeu XVIII-XX siècle (pp. 317-328). Varsovie: Editions de L'Université de Varsovie.

Skowronek, J. (1991). Polacy wobec bałkańskich ruchów narodowych. In W. Balcerak (Ed.), Polska-Bułgaria przez wieki XVII-XX: materiały z sesji Komisji Historycznej Polsko-Bułgarskiej (pp. 31-39). Warszawa: Instytut Historii PAN.

Skowronek, J. (1996). Panslawizm i wizje słowiańskie w warunkach tworzonych przez rozbiory Polski. Przegląd Humanistyczny, 40(1), 193-198.

Skowronek, J. (1997). Europa Środkowo-Wschodnia w projekcie i działalności ks. Adama J. Czartoryskiego (1803-1861). In A. Cetnarowicz, C. Gy. Kiss \& I. Kovacs (Eds.), Wegry Polska w Europie Środkowej. Historia-Literatura. Księga pamiątkowa ku czci Profesora Wacława Felczaka (pp. 105-118). Kraków: Wydawnictwo Profesjonalnej Szkoły Biznesu.

Skowronek, M., Tanty, T. \& Wasilewski, T. (1977). Historia Słowian Zachodnich i Południowych. Warszawa: PWN.

Stankowicz, A. (1996). Rola Austrii w kształtowaniu kultury i życia literackiego w Bośni i Hercegowinie. In M. Bobrownicka (Ed.), Symbioza kultur słowiańskich i niesłowiańskich $w$ Europie Środkowej (pp. 123-128). Kraków: Universitas.

Stankowicz, A. (1997). Bośniacka świadomość historyczna w polityce narodowościowej Austrii. In M. Bobrownicka, L. Suchanek \& F. Ziejka (Eds.), Współcześni Słowianie wobec własnych tradycji i mitów. Sympozjum w Castel Gandolfo w dniach 19-20 maja 1996 (pp. 87-94). Kraków: Universitas.

Stankowicz, A. (2003). Jedność wielokulturowej Bośni i Hercegowiny. Prace Komisji Środkowoeuropejskiej PAU, 11, 35-47.

Stankowicz, A. (2004). Między bośniackościa a jugoslawizmem: z dziejów kultury bośniackiej. Bielsko-Biała: Wydawnictwo AT-H.

Stawowy-Kawka, I. (2000). Historia Macedonii. Wrocław: Zakład Narodowy im. Ossolińskich.

Stawowy-Kawka, I. (2002). Kosowo - problemy narodowe. Prace Komisji Środkowoeuropejskiej, 10, 39-57.

Stawowy-Kawka, I. (2014). Albańczycy w Macedonii 1944-2001. Kraków: Wydawnictwo UJ.

Stawowy-Kawka, I. (Ed.). (2005). Miejsce Macedonii na Bałkanach: historia, polityka, kultura, nauka. Kraków: Wydawnictwo Uniwersytetu Jagiellońskiego.

Stawowy-Kawka, I. (Ed.). (2007). Obraz konfliktów między narodami słowiańskimi w XIX i XX wieku w historiografii. Kraków: Wydawnictwo UJ.

Stępnik, K. (2014). Macedonia w prasie polskiej (1903-1914). Lublin: Wydawnictwo UMCS. 
Stępnik, K., \& Gabryś, M. (Eds.). (2010). Południowa Słowiańszczyzna w literaturze polskiej XIX $i$ XX wieku. Lublin: Wydawnictwo UMCS.

Szczepański, W. (2006). Serbowie a Albańczycy w latach 1878-1918. Dzieje Najnowsze, 38(1), 195-200.

Szczepański, W. (2007). Mity i stereotypy: stosunek elit serbskich do Albańczyków z wilajetu kosowskiego (1878-1912). Przegląd Zachodni, 63(3), 143-156.

Szczepański, W. (2009). Ponad granicami, podziałami i uprzedzeniami: Dimitrijr Tucović o Albańczykach, relacjach serbsko-albańskich i Kosowie. Balcanica Posnaniensia. Acta et studia, 15, 189-206.

Szczepański, W. (2010). Kosowo (zarys historii polityczno-społecznej). Przegląd Zachodni, 66(1), $115-139$.

Szczepański, W. (2013). Cele polityczne i terytorialne Królestwa Czarnogóry w przededniu i w trakcie I wojny bałkańskiej. Balcanica Posnaniensia. Acta et studia, 20, 117-136.

Świątek, A. (2017). “Gazeta Narodowa” wobec powstania w Boce Kotorskiej w 1869 roku. In J. Pezda \& S. Pijaj (Eds.), Europa Środkowa Bałkany i Polacy. Studia ofiarowane profesorowi Antoniemu Cetnarowiczowi (pp. 383-394). Kraków: Historia Iagellonica.

Tokarz, E. (1994). Poljska slovenistika v okviru poljsko-slovenskih stikov. Slavistična revija, 42(2/3), 393-398.

Waldenberg, M. (2000). Jugosławia: byt wspólny i rozpad. Warszawa: Trio.

Waldenberg, M. (2005). Rozbicie Jugosławii. Od separacji Słowenii do wojny kosowskiej. Warszawa: Scholar.

Wereszycki, H. (2015). Pod berłem Habsburgów. Zagadnienia narodowościowe. Kraków: Wydawnictwo Literackie.

Wichniewicz, P. (2015). Zapomniani koloniści w północnej Bośni. In R. Sendek, K. Popek \& M. Maszkiewicz (Eds.), Przestrzenie, których już nie ma: pamięć w południowej i zachodniej Słowiańszczyźnie (pp. 167-180). Kraków: Scriptum.

Wichniewicz, P. (2017). Powroty: polska mniejszość narodowa w Ćelinovacu, Bośnia i Hercegovina. In M. Lachowicz \& K. Polasik-Wrzosek (Eds.), Język polski jako nośnik tożsamości (pp. 107-120). Poznań: Instytut Wschodni UAM.

Wołek, K. (2004). Między Orientem a swojszczyzną - obraz Dalmacji w XIX-wiecznym podróżopisarstwie polskim. Pamiętnik Słowiański, 54, 29-50.

Wrocławski, K., Bogusławska M., \& Różycki, N. (Eds.). (2003). Polacy w Bośni, Polacy o Bośni: przewodnik bibliograficzny z komentarzami. Warszawa: Uniwersytet Warszawski. Instytut Slawistyki Zachodniej i Południowej.

Wrocławski, K., \& Bogusławska, M. (2007). Polska i Czarnogóra: bibliografia, komentarze. Warszawa: Instytut Slawistyki Zachodniej i Południowej UW.

Wrocławski, K., Bogusławska, M., \& Wróblewska-Trochimiuk, E. (2009). Polska i Macedonia: bibliografia, komentarze, studia. Warszawa: Instytut Slawistyki Zachodniej i Południowej Uniwersytetu Warszawskiego.

Zalewski, K. M. (2010). Naród, religia, rasa: muzułmańskie ideologie i ruchy narodowe pogranicza w Południowo-Wschodniej Europie: przykład Sandżaka nowopazarskiego w XX wieku. Warszawa: Wydawnictwo Trio. 
Zieliński, B. (1998). Serbska powieść historyczna. Studia na źródłami, ideami i kierunkami rozwoju. Poznań: Wydawnictwo Naukowe UAM.

Zieliński, B. (2002a). Narodowy i ponadnarodowy model kultury w Europie Środkowej. Pamiętnik Słowiański, 52, 99-102.

Zieliński, B. (Ed.). (2002b). Narodowy i ponadnarodowy model kultury. Europa Środkowa i Półwysep Bałkański. Poznań: Wydawnictwo Naukowe UAM.

Zieliński, B. (2009). Stereotypizacja Słowiańszczyzny południowej w polskim dyskursie publicznym III Rzeczypospolitej (po roku 1989). Południowosłowiańskie Zeszyty Naukowe, 6, 11-23.

Zieliński, B. (2012). Topografia tożsamości, Vol. 1. Poznań: Wydawnictwo Naukowe UAM.

Znamierowska-Rakk, E. (2000). Z dziejów bałkańskich koncepcji federacyjnych (od schyłku XVIII w. do końca I wojny światowej). Studia z Dziejów Rosji i Europy Środkowo-Wschodniej, 35, 5-23.

Żurek, P. (2003). Relacje kardynała Mieczysława Ledóchowskiego z Kościołem katolickim w Serbii w II połowie XIX wieku. Przegląd Historyczny, 94(1), 23-41.

Żurek, P. (2004). Nowa interpretacja genezy "Načertanija" - serbocentryzm Hotelu Lambert a Chorwaci. In A. W. Mikołajczak, W. Szulc \& B. Zieliński (Eds.), Idee wspólnotowe Słowiańszczyzny południowej (pp. 109-120). Poznań: Wydawnictwo Naukowe UAM.

Żurek, P. (2005a). Akcja Hotelu Lambert na rzecz obalenia bana Chorwacji Josipa Jelačicia w dobie Wiosny Ludów. Przegląd Historyczny, 96(3), 434-448.

Żurek, P. (2005b). Hotel Lambert i Chorwaci (1848-1850). Warszawa: Bellona.

Żurek, P. (2005c). Tajne porozumienie Hotelu Lambert z Chorwacką Partią Narodową w świetle raportów Franciszka Zacha (1844). Prace Komisji Środkowoeuropejskiej PAU, 13, 141-148.

Żurek, P. (2006). Polska i Polacy w życiu Josipa Juraja Strossmayera. Bielsko-Biała: Wydawnictwo Akademii Techniczno-Humanistycznej.

Żurek, P. (2007a). Chorwacja i Chorwaci w tradycji rodu Sapiehów. In K. Stępnik (Ed.), Sapiehowie epoki Kodynia i Krasiczyna (pp. 517-525). Lublin: Wydawnictwo Uniwersytetu Marii Curie-Skłodowskiej.

Żurek, P. (2007b). Geneza idei jugosłowiańskiej jako problem historyczny. In I. Stawowy-Kawka (Ed.), Obraz konfliktów między narodami słowiańskimi w XIX i XX wieku w historiografii (pp. 111-116). Kraków: Wydawnictwo UJ.

Żurek, P. (2007c). Strossmayer i Poljaci. In M. Dąbrowska-Partyka \& M. Czerwiński (Eds.), Josip Juraj Strossmayer. Hrvatska, ekumenizam, Europa / Chorwacja, ekumenizm, Europa (pp. 309-321). Kraków: Scriptum.

Żurek, P. (2008). Poljska i Poljaci u životu Josipa Juraja Strossmayera. Slavonski Brod: Hrvatski institut za povijest - Podružnica za povijest Slavonije, Srijema i Baranje.

Żurek, P. (2012a). Andrija Torkvat Brlić i Hotel Lambert. In Zbornik o Andriji Torkvatu Briću (D. Župan, Ed.) (pp. 155-168). Slavonski Brod: Hrvatski institut za povijest - Podružnica za povijest Slavonije, Srijema i Baranje.

Żurek, P. (2012b). Narodowość czarnogórska w dualizmie tożsamości przed II wojną światową i po niej. In M. Fic \& R. Kaczmarek (Eds.), Wieki stare i nowe, Special Volume: Ludzie i elity pogranicza (pp. 246-256). Katowice: Uniwersytet Śląski.

Żurek, P. (2012c). Sječanski ustanak 1863 u Polskoj i Eugen Kvaternik. Slavonski Brod: Hrvatski institut za povijest - Podružnica za povijest Slavonije, Srijema i Baranje. 
Żurek, P. (2013). Podwójne pogranicze. Rzecz o specyfice sąsiedztwa czarnogórsko-serbskiego. In R. Łoś \& J. Regina-Zacharski (Eds.), Sąsiedztwo i pogranicze. Między konfliktem a wspótpraca (Vol. 2, pp. 59-65). Łódź: Wydawnictwo Uniwersytetu Łódzkiego.

Żurek, P. (2015). Pokušaji stvaranja agencije Hotela Lambert u Bosni. In T. J. Lis \& M. Maleszka (Eds.), Poljska u Bosni, Bosna u Poljskoj (pp. 13-31). Kraków-Toruń-Sarajevo: Libron.

Żurek, P. (2017). Miejsce Bośni w bałkańskiej polityce Hotelu Lambert (1843-1849). In J. Pezda \& S. Pijaj (Eds.), Europa Środkowa Bałkany i Polacy. Studia ofiarowane profesorowi Antoniemu Cetnarowiczowi (pp. 371-382). Kraków: Historia Iagellonica.

Żurek, P. (Ed.). (2007). Polska i Chorwacja w Europie Środkowej (integracja europejska $w$ tradycji i przeszłości). Bielsko-Biała: Wydział Humanistyczno-Społeczny ATH.

Żurek, P., \& Lupis, V. (2012). Poljski ustanak 1863 i Dubrovnik, Zagreb: Veleposlanstvo Republike Poljske.

Вяземская, Е. К. (2011). Влияние миграции на территории Боснии и Герцеговины на положение местных этнических групп населения в начале XX века. In T. А. Покивайлова et al. (ред.). Миграция и эмиграция в странах Центральной и Юго-восточной Европь в XVIII-ХХ вв.: сохранение национальной идентичности и историко-культурного наследия России (рр. 162-202). Санкт-Петербург: Алетейя.

Гиза, А. (2001). Балканските дьржави и Македонският въпрос. Прев. Д. Димитров. София: Македонски Научен Институт.

\section{BIBLIOGRAPHY}

\section{(TRANSLITERATION)}

Agičić, D. (1998). Krótki rys stosunków chorwacko-polskich na przestrzeni dziejów. Proglas, 8, 6-8.

Agičić, D. (2000). Echa powstania styczniowego w Chorwacji. Prace Komisji Środkowoeuropejskiej PAU, 8, 39-48.

Agičić, D. (2003). Idee niepodległościowe wśród Chorwatów do I wojny światowej (1860-1914). In I. Stawowy-Kawka \& W. Rojek (Eds.), Państwa europejskie na drodze do niepodległości ( $w$ drugiej połowie XIX i XX wieku). Studia ofiarowane Profesorowi Marianowi Zgórniakowi (pp. 35-40). Kraków: Historia Iagellonica.

Agičić, D. (2007). Kongresi jugoslavenskih povjesničara - mjesto suradnje Ili polje sukoba. In I. Stawowy-Kawka (Ed.), Obraz konfliktów miedzy narodami słowiańskimi w XIX i XX wieku w historiografii (pp. 117-130). Kraków: Wydawnictwo Uniwersytetu Jagiellońskiego.

Balcer, A. (2008). Zarys rozwoju bośniackiej tożsamości narodowej w Bośni. In P. Żurek (Ed.), Tantum Historiae. Księga ofiarowana profesorowi Mieczysławowi Tantemu w osiemdziesiątą rocznice urodzin (pp. 25-41). Bielsko-Biała: Media Silesia. 
Batowski, H. (1938). Państwa bałkańskie 1800-1932. Zarys historii dyplomatycznej i rozwoju terytorialnego. Kraków: Skł. gł.: Kasa im. Mianowskiego w Warszawie.

Batowski, H. (1994). Czy Austro-Węgry mogły przetrwać? Przegląd Polityczny, 7, 17-33.

Bobrownicka, M. (1992). Antyteza słowiańsko-europejska. Z problematyki stereotypu. In T. Dąbek-Wirgowa \& A. Z. Makowiecki (Eds.), Europa w kulturach słowiańskich (pp. 13-19). Warszawa: Uniwersytet Warszawski, Wydział Polonistyki.

Bobrownicka, M. (1995). Narkotyk mitu. Szkice o świadomości narodowej i kulturowej Słowian zachodnich i południowych. Kraków: Universitas.

Bobrownicka, M. (1997). Utopie i polityka. Relacje naród-państwo w ideologii odrodzenia narodowego Słowian Zachodnich i Południowych. In M. Bobrownicka, L. Suchanek \& F. Ziejka (Eds.), Współcześni Słowianie wobec własnych tradycji i mitów. Sympozjum w Castel Gandolfo w dniach 19-20 maja 1996 (pp. 23-38). Kraków: Universitas.

Bobrownicka, M. (2002). Lud - Naród - Społeczeństwo. Kategorie zbiorowej tożsamości w odrodzeniu narodowym Słowian habsburskich. Pamiętnik Słowiański, 52, 3-20.

Bobrownicka, M. (2003). Pogranicze w centrum Europy. Slavica. Kraków: Universitas.

Bobrownicka, M. (2006). Patologie tożsamości narodowej w postkomunistycznych krajach słowiańskich. Kraków: Universitas.

Bobrownicka, M. (Ed.), (1992). Mity narodowe w literaturach słowiańskich. Studia poświęcone XI Międzynarodowemu Kongresowi Slawistów w Bratysławie. Kraków: Uniwersytet Jagielloński.

Bobrownicka, M., Suchanek, L., \& Ziejka, F. (Eds.). (1997). Współcześni Słowianie wobec własnych tradycji i mitów. Sympozjum w Castel Gandolfo w dniach 19-20 maja 1996. Kraków: Universitas.

Bogusławska, M. (2005a). Obraz stosunków międzywyznaniowych w Bośni i Hercegowinie końca XIX wieku w zapisach z podróży ks. Marcina Czermińskiego. Pamiętnik Słowiański, 55(1), 59-76.

Bogusławska, M. (2005b). Tatuaż w komunikacji międzykulturowej w Bośni i Hercegowinie końca XIX wieku. In J. Goszczyńska (Ed.), Problemy tożsamości kulturowej w krajach słowiańskich (Vol. 3. Jej znaki i symbole, pp. 207-224). Warszawa: ISZiP.

Bogusławska, M. (2006). Wyprawy do źródeł czasu: obraz Czarnogóry w polskich relacjach podróżniczych z XIX wieku. In P. Bunjak (Ed.), 110 godina polonistike u Srbiji (pp. 277-285). Beograd: Slavističko društvo Srbije.

Borowiec, A. (1992). Mit Ilirii - czy chorwacki odwrót od Europy? In T. Dąbek-Wigrowa \& A. Makowiecki (Eds.), Kategorie Europy w kulturach słowiańskich (pp. 139-144). Warszawa: Uniwersytet Warszawski, Wydział Polonistyki.

Borowiec, A. (2005). Reinterpretacje kultury dawnej we współczesnej kulturze chorwackiej. In M. Dąbrowska-Partyka (Ed.), W poszukiwaniu nowego kanonu. Re-interpretacje tradycji kulturalnej w państwach postjugosłowiańskich po 1995 roku (pp. 339-350). Kraków: Wydawnictwo Uniwersytetu Jagiellońskiego.

Bujak, J. (2012). Galicjanie i Serbowie = Galicjani i Srby. Jelenia Góra: Wydawnictwo Ad Rem. Bujak, J. (2014). Galicjanie i Serbowie, Part 2: W Bośni. Jelenia Góra: Wydawnictwo Ad Rem. Bujak, J. (2017). Polskie parafie w Bośni w latach 1891-1946. Jelenia Góra: Wydawnictwo Ad Rem. 
Cetnarowicz, A. (1989). Fürst Miloš Obrenović in den ersten Konzeptionen der Balkanpolitik des Hotels Lambert. Österreichische Osthefte, 31(3), 373-381.

Cetnarowicz, A. (1990a). Słoweński ruch narodowy i jego stosunek do spraw polskich 1848-1879. Kraków: Uniwersytet Jagielloński.

Cetnarowicz, A. (1990b). Udio i uloga Hotela Lambert u političkoj srpskoj kizi 1842-1843. godine. Historijski zbornik, 43, 271-285.

Cetnarowicz, A. (1991). Akcja dyplomatyczna obozu Czartoryskiego na rzecz utrzymania ks. Aleksandra Karadziordzievicia na tronie serbskim w roku 1843. Studia Polono-Danubiana et Balcanica, 4, 7-23.

Cetnarowicz, A. (1992a). Slovenci in politika polskih poslancev v Državnem zboru v letih 1867-1868. Zgodovinski časopis, 46(1), 33-39.

Cetnarowicz, A. (1992b). Stosunek Słowenii do spraw polskich w połowie XIX wieku. In J. Toporišič, T. Lopar \& F. Jakopin (Eds.), Miklošičev zbornik. Mednarodni simpozij v Ljubljani od 26. Do 29. julija 1991 (pp. 603-616). Ljubljana: Slovenska akademija znanosti in umetnosti v Ljubljani.

Cetnarowicz, A. (1993a). Misja Michała Czajkowskiego w Belgradzie w roku 1843 i jej rezultaty. In W. Frazik (Ed.), Przez dwa stulecia XIX i XX. Studia historyczne ofiarowane Prof. Wactawowi Felczakowi (pp. 169-182). Kraków: Instytut Teologiczny Księży Misjonarzy.

Cetnarowicz, A. (1993b). Słoweńskie programy narodowe do roku 1914. Prace Komisji Środkowoeuropejskiej PAU, 1, 33-50.

Cetnarowicz, A. (1993c). Tajna dyplomacja Adama Jerzego Czartoryskiego na Bałkanach. Hotel Lambert a kryzys serbski w latach 1840-1844. Kraków: Uniwersytet Jagielloński.

Cetnarowicz, A. (1993d). “Zjednoczona Słowenia”. Z problematyki słoweńskiego ruch narodowego w połowie XIX wieku. Balcanica Posnaniensia. Acta et studia, 6, 63-77.

Cetnarowicz, A. (1994). Slovenci in vprašanje gališke avtonomije v letih 1868-1874. Zgodovinski časopis, 48(4), 519-535.

Cetnarowicz, A. (1995). Wkład Polaków w kształtowaniu się idei jedności wśród Słowian południowych. Studia Polono-Danubiana et Balcanica, 7, 33-44.

Cetnarowicz, A. (1996a). Die Polen und die Slowenen in der Habsburgermonarchie. Ein Blick auf die wechselseitigen Beziehungen der beiden Nationen in der zweiten Hälfte des 19. Jahrhunderts. Studia Austro-Polonica, 5, 229-250

Cetnarowicz, A. (1996b). Słoweńcy i Niemcy w XIX wieku. Z dziejów trudnego współżycia. In M. Bobrownicka (Ed.), Symbioza kultur słowiańskich i niesłowiańskich w Europie Środkowej (pp. 107-116). Kraków: Universitas.

Cetnarowicz, A. (1997a). Polacy i Słoweńcy w monarchii habsburskiej. Uwagi na temat wzajemnych stosunków w drugiej połowie XIX wieku. Studia Austro-Polonica, 5, 203-220.

Cetnarowicz, A. (1997b). Udział Polaków w rozwoju ruchów narodowych i idei zjednoczeniowej wśród Słowian południowych. In M. Bobrownicka, L. Suchanek \& F. Ziejka (Eds.), Współcześni Słowianie wobec własnych tradycji i mitów. Sympozjum w Castel Gandolfo w dniach 19-20 maja 1996 (pp. 105-118). Kraków: Universitas.

Cetnarowicz, A. (1997c). Z problematyki ruchu narodowego w Dalmacji w XIX wieku. Między autonomią a zjednoczeniem z Chorwacją i Slawonią. Studia Polono-Danubiana et Balcanica, 12, 27-35. 
Cetnarowicz, A. (1998a). Das Verhältnis der polnischen Abgeordneten zu den südslawischen Völkern im österreichischen Reichsrat in den 70-er Jahren des 19. Jahrhunderts. In Z. Kowalska (Ed.), Aus der Geschichte Österreichs im Mitteleuropa (pp. 127-147). Wien: Janineum Verlag.

Cetnarowicz, A. (1998b). Die Nationalbewegung der Südslawen und die Polen. In H. Timmermann (Ed.), Entwicklung der Nationalbewegungen in Europa 1850-1918 (pp. 237-247). Berlin: Duncker\&Humblot.

Cetnarowicz, A. (1998c). Opinie prasy galicyjskiej na temat walki narodowej Słoweńców w pierwszych latach dualizmu. In A. Giza (Ed.), Rosja-Polaka-Bałkany w XVIII-XX wieku. Księga pamiątkowa ofiarowana Prof. Mieczysławowi Tantemu (pp. 211-226). Szczecin: Wydawnictwo Naukowe Uniwersytetu Szczecińskiego.

Cetnarowicz, A. (2001a). Chorwacja. In Encyklopedia Historyczna Świata (Vol. 8, Part 1. Europa, pp. 130-147). Kraków: Opres.

Cetnarowicz, A. (2001b). Dalmacja jako teren wyprawy dywersyjnej przeciwko Austrii na początku lat sześćdziesiątych XIX wieku. In I. Stawowy-Kawka \& W. Rojek (Eds.), Państwa europejskie na drodze do niepodległości ( $w$ drugiej połowie XIX i XX wieku). Studia ofiarowane Profesorowi Marianowi Zgórniakowi (pp. 41-53). Kraków: Historia Iagellonica.

Cetnarowicz, A. (2001c). Die slowenishe Nationalbewegung in den Augen der galizischen Presse in der ersten Jahren des Dualismus (1867-1870). In V. Rajšp, R. Bertož, J. Cvirn, W. Lukan. J. Fischer \& B. Marušič (Eds.), Melikov zbornik. Slovenci v zgodovini in njihovi srednjeevropski sosedje (pp. 569-586). Ljubljana: Založba ZRC SAZU.

Cetnarowicz, A. (2001d). Odrodzenie narodowe w Dalmacji. Od "slavenstva" do nowoczesnej chorwackiej i serbskiej idei narodowej. Kraków: Wydawnictwo Uniwersytetu Jagiellońskiego.

Cetnarowicz, A. (2001e). Powstanie i działalność stronnictwa narodowego w Dalmacji w latach 1860-1866. Prace Komisji Środkowoeuropejskiej PAU, 9, 43-71.

Cetnarowicz, A. (2001f). Powstanie w Boce Kotorskiej 1869 - lokalny konflikt, czy początek ogólnego ruchu Słowian południowych. Studia Historyczne, 44(2), 313-322.

Cetnarowicz, A. (2001g). Słowenia. In Encyklopedia Historyczna Świata (Vol. 9, Part 2. Europa, pp. 183-197). Kraków: Opres.

Cetnarowicz, A. (2001h). Stosunki serbsko-chorwackie w Dalmacji w okresie odrodzenia narodowego (1860-1880). In E. Orman \& A. Cetnarowicz (Eds.), H. Wereszycki (1898-1990). Historia $w \dot{z} y c i u$ historyka (pp. 367-378). Kraków: Historia Iagellonica.

Cetnarowicz, A. (2001i). Włoskie, węgierskie i polskie plany ekspedycji do Dalmacji w latach 1864-1866. Zeszyty Naukowe UJ. Prace Historyczne, 128, 101-109.

Cetnarowicz, A. (2002a). Die Slowenen und die anderen Südslawen in der öffentlichen Meinung der Polen im 19. Jahrhundert. In A. Moritsch \& A. Moser (Eds.), Den Anderen im Blick. Stereotype im ehemaligen Jugoslawien (pp. 141-152). Frankfurt/Main: Peter Lang.

Cetnarowicz, A. (2002b). Ruch narodowy w Dalmacji na łamach prasy galicyjskiej w latach sześćdziesiątych XIX wieku. In K. Ślusarek (Ed.), Polska i Polacy w XIX i XX wieku. Studia ofiarowane Prof. Mariuszowi Kulczykowskiemu w 70. rocznicę Jego urodzin (pp. 157-180). Kraków: Historia Iagellonica.

Cetnarowicz, A. (2003a). Odjek narodnog preporoda u Dalmaciji na stranicama galicijskog tiska (1860-1880). In A. Buczynski, M. Kruhek \& S. Matković (Eds.), Hereditas rerum Croaticarum od honorem Mirko Valentić (pp. 184-193). Zagreb: Hrvatski institut za povijest. 
Cetnarowicz, A. (2003b). Polityka bałkańska Hotelu Lambert. In Z. Baran (Ed.), Czartoryscy Polska - Europa. Historia i wspótczesność (pp. 160-167). Kraków: DjaF.

Cetnarowicz, A. (2004). Koncepcje federalistyczne wśród Słowian południowych (do roku 1914). In K. Ślusarek (Ed.), Europa unii i federacji. Idea jedności narodów i państw od średniowiecza do czasów współczesnych (pp. 259-272). Kraków: Historia Iagellonica.

Cetnarowicz, A. (2005). Die polnische Beitrag in der Gestaltung der Einheitsidee bei den Südslawen. In K. Sládek \& D. Škvarna (Eds.), Hl'adanie novej podoby strednej Európy (fenomén integrácie a dezintegrácie od osvietenstva po 1. svetovú vojnu) (pp. 88-97). Bratislava: Vydavatel'stvo Michala Vaška v Prešove pre Centrum pre európsku politiku Bratislava.

Cetnarowicz, A. (2006a). Kwestia wyznaniowa w procesie kształtowania się chorwackiej i serbskiej idei narodowej w Dalmacji w XIX wieku. In D. Quirini-Popławska (Ed.), Portolana. Studia Mediterranea (Vol. 2. Religie świata śródziemnomorskiego, pp. 259-269). Kraków: Wydawnictwo Uniwersytetu Jagiellońskiego.

Cetnarowicz, A. (2006b). Narodni preporod u Dalmaciji. Od "slavenstva" prema modernoj hrvatskoj i srpskoj narodnoj ideji. Zagreb: Srednja Europa.

Cetnarowicz, A. (2006c). Odrodzenie narodowe w Istrii w latach 1860-1907 - zarys problematyki. In A. Patek \& W. Rojek (Eds.), Naród Państwo. Europa Środkowa w XIX i XX wieku. Studia ofiarowane Michałowi Pułaskiemu w pięćdziesięciolecie pracy naukowej (pp. 35-44). Kraków: Wydawnictwo Uniwersytetu Jagiellońskiego.

Cetnarowicz, A. (2006d). Udział polskiej emigracji w kryzysie serbskim na początku lat 40-tych XIX wieku. In P. Bunjak (Ed.), 110 godina polonistike u Srbiji (pp. 267-275). Beograd: Slavističko društvo Srbije.

Cetnarowicz, A. (2007a). Die Entwicklung der modernen kroatischen und serbischen Nationalidee in Dalmatien in der zweiten Hälfte des 19. Jahrhunderts. Ein Beitrag zur Diskussion über die Entstehung von Nationalitäten. In E. Brix, A. Suppan \& E. Vyslonzil (Eds.), Südosteuropa. Traditionen als Macht (pp. 51-64). Wien: Oldenbourg Wissenschaftsverlag.

Cetnarowicz, A. (2007b). Polsko-słoweńskie związki polityczne w XIX wieku. In J. Purchla (Ed.), Kraków-Lublana a mit Europy Środkowej (pp. 123-138). Kraków: MCK.

Cetnarowicz, A. (2007c). Sprawa statusu Dalmacji w latach 1865-1868 - niewykorzystana szansa Węgier. In A. Cetnarowicz \& S. Pijaj (Eds.), Węgry i dookoła Węgier... Narody Europy Środkowej w walce o wolność i tożsamość w XIX i XX wieku. Materiały z konferencji dotyczącej problematyki narodowościowej w Europie Środkowej zorganizowanej z okazji 10 rocznicy śmierci Prof. Wacława Felczaka (Kraków 12-13 XII 2003) (pp. 123-136). Kraków: Historia Iagellonica.

Cetnarowicz, A. (2008a). Die Nationalbewegung in Dalmatien im 19. Jahrhundert. Von "Slaventum" bis zur modernen kroatischen und serbischen Nationalidee. Frankfurt/Main: Peter Lang Verlag.

Cetnarowicz, A. (2008b). Mosty i przepaście. Kształtowanie się świadomości narodowej i idei jedności wśród Słowian południowych w XIX wieku. In P. Żurek (Ed.), Tantum Historiae. Ksiega ofiarowana profesorowi Mieczysławowi Tantemu w osiemdziesiąta rocznice urodzin (pp. 42-54). Bielsko-Biała.

Cetnarowicz, A. (2009a). "Mit Sicherheit wird man auch bei uns so vorgehen...” Die Haltung der Slowenen zur Lage der Polen in preussischen Teilungsgebiet. In E. Dmitrów \& T. Weger 
(Eds.), Deutschlands östlicie Nachbarschaften. Eine Sammlung von historischen Essays für Hans Henning Hahn (pp. 411-428). Fraknfurt/Main: Peter Lang.

Cetnarowicz, A. (2009b). Die Slawen der Habsburgermonarchie - Wege ihrer nationalen Emanzipation im 19. Jahrhundert. In A. Perłkowski, R. Bartczak \& A. Schindling (Eds.), Reiche Mitteleuropas in der Neuzeit. Integration und Herrschaft, Liber memorabilis Jan Pirożyński (pp. 261-270). Kraków: Księgarnia Akademicka.

Cetnarowicz, A. (2009c). Religion und Südslawische Nation. Die Konfessionelle Frage und die Formierung der modernen kroatischen und serbischen Nationalidee in Dalmatien im 19. Jahrhundert. Historishes Jahrbuch, 129, 461-477.

Cetnarowicz, A. (2009d). The Forging of Modern National Identity. Slavic Nations in the Habsburg Monarchy in the 19th Century. In J. Kłoczowski \& H. Łaszkiewicz (Eds.), East-Central Europe in European History. Themes and Debates (pp. 255-270). Lublin: The Institute of East-Central Europe.

Cetnarowicz, A. (2009e). Živio i evviva! Początki sporu o tożsamość Istrii w XIX wieku. In D. Quirini-Popławska (Ed.), Portolana, Studia Mediterranea (Vol. 4. Mare inclitum. Oddziaływanie cywilizacji śródziemnomorskiej, pp. 269-280). Kraków: Wydawnictwo Uniwersytetu Jagiellońskiego.

Cetnarowicz, A. (2010a). Hrvatski i slovenski narodni pokret u Istri u razdoblju jačanja taljanskog iredentizma u prvih godinama dualizma. Hisorijski zbornik, 63(2), 437-454.

Cetnarowicz, A. (2010b). Odrodzenie narodowe w Istrii w latach 1860-1907. Kraków: Historia Iagellonica.

Cetnarowicz, A. (2011a). Dalmatinski narodnjaci o Sječanskom ustanku u Polskoj 1863. godine. In I. Ivelić (Ed.), Zbornik Nikše Stančića (pp. 151-163). Zagreb: Filozofski fakultet Sveučilišta u Zagrebu, Odsjek za povijest - FF press.

Cetnarowicz, A. (2011b). Vom "Slawentum" zur modernen kroatischen und serbischen Nationalidee. Ein Beitrag zur kroatisch-serbischen Beziehungen in Dalmatien während der nationalen “Wiedergeburt” in den Jahren 1860-1880. In I. Breneselović (Ed.), Spomenica Baltazara Bogišića o stogodišnjici njegove smrti 24. aprila 2005 godine (Vol. 1, pp. 39-50). Beograd: Službeni glasnik - Institut za uporedno pravo.

Cetnarowicz, A. (2011c). Życie polityczne w Galicji z perspektywy słoweńskiego i chorwackiego ruchu narodowego. In A. Kawalec, W. Wierzbieniec \& I. Zaszkliniak (Eds.), Galicja 1772-1918. Problemy metodologiczne, stan i potrzeby badań (Vol. 1, pp. 325-336). Rzeszów: Wydawnictwo Uniwersytetu Rzeszowskiego.

Cetnarowicz, A. (2012). I movimenti nazionali degli Slavi del Sud nel periodo del Risorgimento. In F. Leoncini (Ed.), L'alba dell'Europa liberale. La trama internazionale delle cospirazioni risorgimentali (pp. 75-85). Rovigo: Ass. Culturale Minelliana.

Cetnarowicz, A. (2013a). "Pisane sercem węgierskim a duszą słowiańską...” Węgrzy, Polacy i Słowianie południowi w twórczości naukowej Wacława Felczaka. In W. Felczak (Ed.), Europa Centralis (pp. IX-XXV). Kraków: Avalon.

Cetnarowicz, A. (2013b). Chorwacki ruch narodowy w Dalmacji wobec powstania styczniowego. In T. Kargol (Ed.), Powstanie styczniowe - odniesienia, interpretacje, pamięć (pp. 37-50). Kraków: Historia Iagellonica.

Cetnarowicz, A. (2013c). Historiografia dziewiętnastowiecznych dziejów krajów słowiańskich w okresie przełomu i w ostatnim piętnastoleciu. In K. Makowski \& M. Saczyńska (Eds.), Słowianie - idea i rzeczywistość. Zbiór studiów (pp. 131-150). Poznań: IH UAM. 
Cetnarowicz, A. (2014a). Aspiracje i programy narodowe Słowian południowych w monarchii habsburskiej w XIX wieku. In M. Koźmiński (Ed.), Cywilizacja europejska - różnorodność i podział (Vol. 3, pp. 277-296). Kraków: Universitas.

Cetnarowicz, A. (2014b). Narodni preporod u Istri (1860-1907). Zagreb: Srednja Europa.

Cetnarowicz, A. (2015a). Stosunki polsko-ukraińskie i polsko-rosyjskie w opinii słoweńskiej w II połowie XIX wieku. Acta historia Neosoliensia. Vedecký časopis pre historicke vedý, 18, 161-179.

Cetnarowicz, A. (2015b). Walka o szkolnictwo narodowe w Istrii w drugiej połowie XIX wieku i sprawa utworzenia chorwackiego gimnazjum w Pazinie. In T. Pudłocki \& K. Stopka (Eds.), Amico socio et viro docto. Księga ku czci Prof. Andrzeja Banacha (pp. 55-71). Kraków: Historia Iagellonica.

Cetnarowicz, A. (2016a). Pod berłem Habsburgów. Polsko-słoweńskie stosunki polityczne w drugiej połowie XIX wieku. In A. Cetnarowicz, D. Nećak, S. Pijaj \& B. Todorović (Eds.), W Galicji i nad Socza. Polacy i Słoweńcy na frontach i wojny światowej / V Galiciji in ob Soči. Poljaki in Slovenci na frontah I svetovne vojne (pp. 13-23). Kraków: Historia Iagellonica.

Cetnarowicz, A. (2016b). Pod žezlom Habsburžanov. Poljsko-slovenski politični odnosi v 2. polovici 19. stoletja. In A. Cetnarowicz, D. Nećak, S. Pijaj \& B. Todorović (Eds.), $W$ Galicji i nad Socza. Polacy i Słoweńcy na frontach $i$ wojny światowej / V Galiciji in ob Soči. Poljaki in Slovenci na frontah I svetovne vojne (pp. 123-132). Kraków: Historia Iagellonica.

Cetnarowicz, A. (2016c). Problematyka słowiańska w twórczości Mirosława Frančicia. In J. Lencznarowicz, J. Pezda \& A. A. Zięba (Eds.), Polacy i świat, kultura i zmiana. Studia historyczne i antropologiczne ofiarowane Profesor Halinie Florkowskiej-Frančić (pp. 505-510). Kraków: Księgarnia Akademicka.

Cetnarowicz, A. (2016d). Procesy kształtowania się nowoczesnych narodów w Europie Środkowej a Polacy. In A. Cetnarowicz \& S. Pijaj (Eds.), Polacy i ich sasiedzi w Europie Środkowej. Związki polityczne i ich odbicie w historiografii (pp. 27-44). Kraków: DiG.

Cetnarowicz, A. (2017a). Kastavština u narodnom preporodu u Istri - usponi te sumnje i okljevanja. Zbornik Kastavštine, 21, 65-77.

Cetnarowicz, A. (2017b). Tajna diplomacija Adama Ježija Čartoriskog na Balkanu. Hotel Lambert i srpska kriza 1840-1844. Beograd: Slavističko društvo Srbije.

Cetnarowicz, A. (2018). Parlamentarna działalność Stefana Mitrova Ljubišy na forum Rady Państwa w Wiedniu. In Ł. Burkiewicz, R. Hryszko, W. Mruk \& P. Wróbel (Eds.), Polonia. Italia. Mediterraneum. Studia ofiarowane Pani Profesor Danucie Quirini-Popławskiej (pp. 375-386). Kraków: Historia Jagellonica.

Chimiak, Ł. (2013). Z dziejów polskiej mniejszości w Bośni. Życie i działalność Wiktora i Artura Burdów. Studia z Dziejów Rosji i Europy Środkowo-Wschodniej, 48(1), 55-74.

Czamańska, I., \& Szulc, W. (2002). Pojęcie Macedonii i Macedończyków w ciągu wieków. In B. Zieliński (Ed.), Wokół Macedonii: siła kultury - kultura siły (pp. 21-33). Poznań: Wydawnictwo Naukowe Uniwersytetu im. Adama Mickiewicza.

Czapik-Lityńska, B. (2007). Problem chorwackiej tożsamości narodowej na tle integracyjnego utopizmu grupy iliryjskiej. Południowosłowiańskie Zeszyty Naukowe, 4, 43-49.

Czapik-Lityńska, B., \& Tokarz, E. (Eds.). (1992). Kryzys tożsamości, Katowice: Uniwersytet Śląski. 
Czerwiński, M. (2005). Elementy dyskusyjnej konstrukcji chorwackiej tożsamości narodowej. Prace Komisji Środkowoeuropejskiej PAU, 13, 7-27.

Czerwiński, M. (2007a). Lik i ideja Josipa Juraja Strossmayera u diskusijama suvremene hrvatske historiografie. In M. Dąbrowska-Partyka \& M. Czerwiński (Eds.), Josip Juraj Strossmayer. Hrvatska, ekumenizam, Europa / Chorwacja, ekumenizm, Europa (pp. 73-86). Kraków: Scriptum.

Czerwiński, M. (2007b). Semiotyka dyskursu historycznego. Chorwackie i serbskie syntezy dziejów narodu. Kraków: Wydawnictwo Uniwersytetu Jagiellońskiego.

Czerwiński, M. (2011). “Jak Kraków Zagrzebiowi...” Historia relacji polsko-chorwackich w kontekście albumu wydanego w roku 1881 / Kao Krakov Zagrebu. Povijest poljsko-hrvatskih odnosa u kontekstu albuma izdanog 1881. godine. In M. Czerwiński \& M. Najbar-Agičić (Eds.), Kraków Zagrzebiowi, reprint z roku 1881 (pp. 7-31). Zagreb: Srednja Europa.

Czerwiński, M. (2012). Semiotyka dyskursu historycznego. Serbskie i chorwackie syntezy historyczne. Kraków: Wydawnictwo Uniwersytetu Jagiellońskiego.

Czerwiński, M. (2014a). Narracje i encyklopedie. Wyobrażenia historyczne Chorwatów i Serbów. Rocznik Antropologii Historii, 1/6, 93-118.

Czerwiński, M. (2014b). Znaki integracji - uniwersum władzy symboli chorwackiego iliryzmu (na marginesie dyskusji o chorwackości odrodzenia narodowego). In M. Dyras, B. Suchoń-Chmiel \& T. Kusek (Eds.), Symbole władzy - władza symboli (pp. 204-228). Kraków: Scriptum.

Czerwiński, M., \& Agičić, D. (Eds.). (2016). Poljsko-hrvatske veze kroz stoljeća. Povijest, kultura, književnost. Zbornik radova sa znanstvenog skupa / Związki polsko-chorwackie na przestrzeni wieków. Historia, kultura, literatura. Zagreb: Srednja Europa.

Darasz, Z. (1995). Problemy autoidentyfikacji kulturowej i narodowej w literaturze słoweńskiej. Katowice: Uniwersytet Śląski.

Darasz, Z. (1996). Impulsy germańsko-romańskie a historyczna promocja literatury słoweńskiej. In M. Bobrownicka (Ed.), Symbioza kultur słowiańskich i niesłowiańskich w Europie Środkowej (pp. 99-108). Kraków: Universitas.

Darasz, Z. (1997a). Niektóre aspekty słoweńskiego dialogu z tradycją narodowej kultury. In M. Bobrownicka, L. Suchanek \& F. Ziejka (Eds.), Współcześni Słowianie wobec własnych tradycji i mitów. Sympozjum w Castel Gandolfo w dniach 19-20 maja 1996 (pp. 77-85). Kraków: Universitas.

Darasz, Z. (1997b). Słoweńcy wobec iliryjskiej utopii. In B. Czapik-Lityńska (Ed.), Utopia $w$ językach i literaturach Słowian, Vol. 2: Z przemian świadomości utopijnej w procesie historycznoliterackim (pp. 78-80). Katowice: Wydawnictwo Uniwersytetu Śląskiego.

Darasz, Z. (2004). Słowiańskie identyfikacje słoweńskiej kultury narodowej. Południowosłowiańskie Zeszyty Naukowe, 1, 97-107.

Darasz, Z. (2007a). Literackie portrety Lublany - dawne i nowe, własne i obce. In J. Purchla (Ed.), Kraków-Lublana a mit Europy Środkowej (pp. 109-121). Kraków: MCK.

Darasz, Z. (2007b). Słowiański wymiar słoweńskości w pismach Janeza Trdiny. Południowosłowiańskie Zeszyty Naukowe, 4, 7-17.

Darasz, Z. (2008). Rijeka w autobiografii słoweńskiego pisarza i etnologa Janeza Trdiny (1830-1905). In M. Bogusławska \& G. Szwat-Gyłybowa (Eds.), Bunt tradycji - tradycja 
buntu, Księga dedykowana Prof. K. Wrocławskiemu (pp. 221-228). Warszawa: Instytut Slawistyki Zachodniej i Południowej Wydziału Polonistyki UW.

Darasz, Z. (2017). Słoweńska literatura i sztuka w “Świecie Słowiańskim”. In J. Pezda \& S. Pijaj (Eds.), Europa Środkowa Bałkany i Polacy. Studia ofiarowane profesorowi Antoniemu Cetnarowiczowi (pp. 429-439). Kraków: Historia Iagellonica.

Dąbrowska-Partyka, M. (2003). Świadectwa i mistyfikacje. Przed i po Jugosławii. Kraków: Wydawnictwo UJ.

Dąbrowska-Partyka, M. (2007). Rola Serbów węgierskich w procesie kształtowania się nowoczesnej tożsamości serbskiej. In A. Cetnarowicz \& S. Pijaj (Eds.), Węgry i dookoła Węgier... Narody Europy Środkowej w walce o wolność i tożsamość w XIX i XX wieku. Materiały $z$ konferencji dotyczącej problematyki narodowościowej w Europie Środkowej zorganizowanej z okazji 10 rocznicy śmierci Prof. Wacława Felczaka (Kraków 12-13 XII 2003) (pp.69-84). Kraków: Historia Iagellonica.

Dąbrowska-Partyka, M. (Ed.) (2005). W poszukiwaniu nowego kanonu. Reinterpretacje tradycji kulturalnej w krajach postjugosłowiańskich po 1995 roku. Kraków: Wydawnictwo Uniwersytetu Jagiellońskiego.

Dmowski, D. (1992). Stosunek Chorwatów do idei przebudowy monarchii habsburskiej w państwo dualistyczne Austro-Węgry. Przegląd Zachodnio-Pomorski, 11, 61-82.

Dmowski, D. (1995). Rozwój ruchu narodowego w Dalmacji w latach 1860-1878. Szczecińskie Studia Historyczne, 9, 35-48.

Dmowski, D. (2000). Rozwój idei jugosłowiańskiej na ziemiach chorwackich na początku XX wieku w kontekście stosunków węgiersko-chorwackich do końca I wojny światowej. Studia z Dziejów Rosji i Europy Środkowo-Wschodniej, 35, 5-23.

Drljača, D. (1997). Między Bośnią, Bukowiną, Serbią i Polską. Studia i szkice etnologiczne. Wrocław: Polskie Towarzystwo Ludoznawcze.

Dymarski, M. (2010a). Konflikty na Bałkanach w okresie kształtowania się państw narodowych w XIX i na początku XX wieku. Wrocław: Wydawnictwo Uniwersytetu Wrocławskiego.

Dymarski, M. (2010b). Kształtowanie się systemu politycznego w Serbii i Bułgarii w XIX i pierwszych latach XX wieku. Prace Komisji Środkowoeuropejskiej PAU, 8, 25-57.

Dymarski, M. (2017a). Macedończyk-Macedończycy w dokumentach dyplomatycznych Królestwa Serbii 1903-1914. Slavica Wratislaviensia, 165, 101-111.

Dymarski, M. (2017b). Stosunki etniczne w Czarnogórze: aspekt historyczny i współczesny. Studia Środkowoeuropejskie i Bałkanistyczne, 25, 207-227.

Dyras, M. (2002a). Chorwackie ucieczki z Bałkanów. Pamiętnik Słowiański, 52(1), 51-56.

Dyras, M. (2002b). Strategie odzyskiwania utraconej tożsamości. Chorwacka "opowieśc” o historii. In B. Zieliński (Ed.), Narodowy i ponadnarodowy model kultury. Europa Środkowa i Półwysep Bałkański (pp. 113-119). Poznań: Wydawnictwo Naukowe Uniwersytetu Adama Mickiewicza.

Dyras, M. (2002c). Strategie odzyskiwania utraconej tożsamości. Chorwacka "powieść o historii”. In B. Zieliński (Ed.), Narodowy i ponadnarodowy model kultury. Europa Środkowa i Pótwysep Bałkański (pp. 113-119). Poznań: Wydawnictwo Naukowe UAM.

Dyras, M. (2004). Wizje przeszłości w chorwackich podręcznikach historii w latach 90-tych XX wieku. Prace Komisji Środkowoeuropejskiej PAU, 12, 165-170. 
Dyras, M. (2007). Kilka uwag o chorwackiej etnogenezie i manipulacjach narodową tożsamością. In J. Axer \& J. Olko (Eds.), Dawne kultury wideologiach XIX i XX wieku (pp. 77-87). Warszawa: DiG.

Dyras, M. (2009a). Re-inkarnacje narodu. Chorwackie narracje tożsamościowe w latach dziewięćdziesiątych XX wieku. Kraków: Wydawnictwo Uniwersytetu Jagiellońskiego.

Dyras, M. (2009b). Zależność od historii jako czynnik świadomości narodowej. In M. Dąbrowska-Partyka (Ed.), Kultury słowiańskie między postkomunizmem a postmodernizmem (pp.63-74). Kraków: Wydawnictwo UJ.

Dyras, M. (2015). Autostereotypy i jak widzą Chorwatów inni. In R. Kusek, J. Purchla \& J. SanteraSzeligi (Eds.), Narody i stereotypy 25 lat później. Nowe granice, nowe horyzonty (pp. 268-281). Kraków: MCK.

Dziadzio, A. (2017). Władza na pograniczach monarchii habsburskiej doby konstytucyjnej wobec niechrześcijańskich mniejszości religijnych. In D. Szpoper \& P. Dąbrowski (Eds.), Pogranicza w historii prawa i myśli polityczno-prawnej: praca zbiorowa (pp. 131-147). Gdańsk-Olsztyn: Wydawnictwo Gdańskiej Szkoły Wyższej.

Dziekan, M. (2011). Islam na Bałkanach w relacji z podróży po Bośni i Hercegowinie ks. Marcina Czermińskiego SJ (1860-1931). Południowosłowiańskie Zeszyty Naukowe. JęzykLiteratura - Kultura, 8, 133-163.

Falski, M. (2004). Dubrownik w chorwackiej przestrzeni kulturowej z perspektywy XIX stulecia. In J. Goszczyńska (Ed.), Problemy tożsamości kulturowej w krajach słowiańskich, 2: Jej formy i przemiany (pp. 35-61). Warszawa: Uniwersytet Warszawski, Instytut Filologii Słowiańskiej.

Falski, M. (2007). Pamięć społeczna a ideologia: z problematyki autodefinicji kultury bośniackiej. Południowosłowiańskie Zeszyty Naukowe. Język - Literatura - Kultura, 4, 51-64.

Falski, M. (2008a). Czym jest "kneži kamen”? Szkic o słoweńskiej polityce symboli. Pamiętnik Słowiański, 58(1), 49-65.

Falski, M. (2008b). Porządkowanie przestrzeni narodowej-przypadek chorwacki. Studium z historii wyobrażeń kulturowych. Warszawa: Wydział Polonistyki Uniwersytetu Warszawskiego.

Falski, M. (2013). Croatian Political Discourse in 1861 and the Main Forms of Public Debate in the Nineteenth Century. Acta Poloniae Historica, 108, 71-92.

Falski, M. (2017). Pierwsza mapa Słowenii. Poznańskie Studia Slawistyczne, 13, 317-334, DOI: https://doi.org/10.14746/pss.2017.13.19

Faszcza, D. (2018). Wojna serbsko-bułgarska 1885 roku. Studium polityczno-wojskowe. Oświęcim: Napoleon V.

Felczak, W. (1963). Słowianie węgierscy wobec sprawy rewolucji węgierskiej i kontrrewolucji w 1848 r. Przegląd Historyczny, 54(4), 572-591.

Felczak, W. (1968). Tajna polityka chorwacka w 1867 r. w świetle nieznanych dokumentów. Studia Historyczne, 11(3), 343-365.

Felczak, W. (1969). Ugoda węgiersko-chorwacka 1868 roku. Wrocław: Ossolineum.

Felczak, W., \& Wasilewski, T. (1985). Historia Jugosławii. Warszawa: Ossolineum.

Filcek, K. (2011). Tożsamość Bośniaków a procesy polityczne w Bośni i Hercegowinie. Społeczeństwo i Polityka, 1, 117-153. 
Gibas-Krzak, D. (2009). Serbsko-albański spór o Kosowo w XX wieku. Uwarunkowania - Przebieg - Konsekwencje. Toruń: Wydawnictwo Adam Marszałek.

Gibas-Krzak, D. (2015). Zmierzch panowania tureckiego na Bałkanach: polityczne, społeczno-kulturowe i militarne uwarunkowania schyłku władania Bośnią i Hercegowiną przez Osmanów. Balcanica Posnaniensia. Acta et studia, 22(2), 15-36.

Gibas-Krzak, D. (2016). Bośnia i Hercegowina: determinanty dziejów. Pomiędzy Serbami, Chorwatami a supremacją Muzułmanów. Częstochowa: Wydawnictwo im. Stanisława Podobińskiego Akademii im. Jana Długosza.

Gil, D. (1995a). Hymnografia serbska i jej rola w kulturze narodowej. Studia nad "Srbljakiem". Kraków: Wydawnictwo Uniwersytetu Jagiellońskiego.

Gil, D. (1995b). Literatura staroserbska w służbie ideologii narodowej. Zeszyty Naukowe UJ. Prace Historycznoliterackie, 90, 43-47.

Gil, D. (2002). Chorwacki biskup Josip Juraj Strossmayer i serbski biskup Mihailo wobec dziewiętnastowiecznej idei narodowej i religijnej. Pamiętnik Słowiański, 52, 47-56.

Gil, D. (2005a). Historia jako fatum. Dzieje narodu i państwa według współczesnych historiografii serbskich. Slavia Meridionalis, 5, 11-30.

Gil, D. (2005b). Kryzys tożsamości. Serbska Cerkiew Prawosławna wobec przemian polityczno-społecznych po 5 X 2000 r. In M. Dąbrowska-Partyka (Ed.), W poszukiwaniu nowego kanonu. Re-interpretacje tradycji kulturalnej w państwach postjugosłowiańskich po 1995 roku (pp. 267-293). Kraków: Wydawnictwo Uniwersytetu Jagiellońskiego.

Gil, D. (2005c). Prawosławie. Historia. Naród. Miejsce kultury duchowej w serbskiej tradycji i współczesności. Kraków: Wydawnictwo Uniwersytetu Jagiellońskiego.

Gil, D. (2007). Serbscy Boszniacy (Bošnjaci): pomiędzy fundamentalizmem a dialogiem międzyreligijnym prawosławnych i muzułmanów w Sandžaku). Prace Komisji Kultury Słowian PAU, 6, 197-223.

Gil, D. (2013). Państwo - Naród - Kościół i specyfika serbskiej religijno-narodowej koncepcji diarchii. In B. Zieliński (Ed.), Język, literatura i kultura Słowian - dawniej i dziś, III: Litteraria (pp. 49-63). Poznań: UAM.

Gil, D. (2017). Ewolucja i funkcje narodu w Serbii od schyłku XVIII wieku. Slavia Meridionalis, 17, DOI: https://doi.org/10.11649/sm.1325

Gil, D. (2018) Narod u istoriozofskim koncepcijama: srpsko-crnogorski katalog ideja. In B. Zieliński (Ed.), Literaturoznawstwo, kulturoznawstwo, folklorystyka: prace na XVI Międzynarodowy Kongres Slawistów w Belgradzie 2018 (pp. 53-61). Poznań: Wydawnictwo Naukowe UAM.

Giza, A. (1988). Oświata w Serbii w latach 1829-1914. Rozprawy z dziejów oświaty, 31, 107-125.

Giza, A. (1990a). Idea jugosłowiańska. Kamena, 3, 37-39.

Giza, A. (1990b). Udział Polaków w powstaniu serbskiego dokumentu państwowego "Načertanija”. Ze skarbca kultury, 50, 135-154.

Giza, A. (1992). Idea jugoslawizmu w latach 1800-1918. Szczecin: Uniwersytet Szczeciński.

Giza, A. (1993a). Austroslawizm w XIX wieku. Przegląd Zachodnio-Pomorski, 1, 109-120.

Giza, A. (1993b). Austroslawizm. Kamena, 3/4, 27-43.

Giza, A. (1994). Narodziny i rozpad Jugosławii. Szczecin: Wydawnictwo Naukowe Uniwersytetu Szczecińskiego. 
Giza, A. (1996). Ziemie macedońskie na przełomie XIX i XX wieku. Szczecin: Wydawnictwo Naukowe US 1996.

Giza, A. (1997). Polskie aspekty jugoslawizmu w latach 1848-1875. Szczecińskie Studia Historyczne, 7, 17-33.

Giza, A. (1998a). Liceum i Wielka Szkoła w Belgradzie oraz ich znaczenie dla rozwoju świadomości narodowej Serbów w XIX wieku. Ze skarbca kultury, 47, 163-178.

Giza, A. (1998b). Państwa bałkańskie wobec kwestii macedońskiej w latach 1878-1918. Szczecin: Wydawnictwa Naukowe US.

Giza, A. (1998c). Powstanie ilindeńskie 1903 roku w Macedonii, Part 1. Szczecińskie Studia Historyczne, 11, 135-115.

Giza, A. (1998d). Sytuacja polityczno-gospodarcza na ziemiach macedońskich pod koniec XIX wieku. In A. Giza (Ed.), Rosja - Polska - Bałkany w XVIII-XX wieku (pp. 187-210). Szczecin: Wydawnictwo Naukowe US.

Giza, A. (2001a). Inteligencja chorwacka w ruchu iliryjskim. Studia Historyczne, 44(3), 405-422.

Giza, A. (2001b). Stosunki narodowościowe na ziemiach macedońskich w początkach XX wieku. Balcanica Posnaniensia. Acta et studia, 11/12, 129-135.

Giza, A. (2001c). Tendencje polityczne Chorwacji na przełomie XIX i XX wieku. In Przemiany społeczno-polityczne na Pomorzu Środkowym w latach 1945-1956. Materiały z konferencji (pp. 185-201). Koszalin: Koszalińska Biblioteka Publiczna im. J. Lelewela.

Giza, A. (2001d). Wieś macedońska na przełomie XIX i XX wieku. Rocznik Historyczny Muzeum Historii Polskiego Ruchu Ludowego, 14, 142-151.

Giza, A. (2001e). Życie polityczne Chorwatów pod koniec XIX wieku. In E. Wilgocki (Ed.), Instantia est mater doctrinae - ksiega jubileuszowa Prof. Władysława Filipiaka (pp. 399-417). Szczecin: Stowarzyszenie Naukowe Archeologów Polskich Oddział w Szczecinie.

Giza, A. (2001f). Balkanskite dŭrzhavi i Makedonskiiat vŭpros (D. Dimitrov, Trans.). Sofiia: Makedonski Nauchen Institut.

Giza, A. (2002a). Bośnia i Hercegowina w dobie tureckiego i austriackiego panowania (1800-1914). Szczecin: Wydawnictwo Naukowe US.

Giza, A. (2002b). Bośnia i Hercegowina w dobie wielkiego kryzysu bałkańskiego w latach 1875-1878. Studia Historyczne, 1, 17-39.

Giza, A. (2002c). Od aneksji Bośni i Hercegowiny do zamachu w Sarajewie. Szkice Podlaskie, $10,53-74$.

Giza, A. (2002d). Ziemie chorwackie w połowie XIX wieku. In A. Czubiński, B. Lapis \& Cz. Łuczak (Eds.), Społeczeństwo, armia i polityka w dziejach Polski i Europy. Studia z dziejów politycznych $i$ wojskowych dedykowane profesorowi Benonowi Miśkiewiczowi z okazji jubileuszu siedemdziesięciolecia urodzin (pp. 395-413). Poznań: Instytut Historii UAM.

Giza, A. (2003). Bułgaria i problem macedoński od początku XVIII do lat trzydziestych XX wieku. Szczecin: Wydawnictwo Naukowe Uniwersytetu Szczecińskiego.

Goszczyńska, J. (Ed.). (2005). Problemy tożsamości kulturowej w krajach słowiańskich 3. Warszawa: Uniwersytet Warszawski, Instytut Filologii Słowiańskiej.

Gregorczyk, D. (2007). Misje księdza Marcina Czermińskiego SJ do Polonii bośniackiej w latach 1898-1909. Studia Bobolanum, 3, 47-64. 
Gregorczyk, D. (2010). Polityczne i militarne aspekty wojny Turcji z Serbią i Czarnogórą w latach 1876-1878. In R. Jankowska (Ed.), Turecka droga do Unii Europejskiej (pp. 85-102). Katowice: Rada Samorządu Studenckiego Międzynarodowej Szkoły Nauk Politycznych Uniwersytetu Śląskiego.

Gregorczyk, D. (2010). Polscy urzędnicy w administracji Bośni i Hercegowiny w latach 1879-1914. Roczniki Administracji i Prawa, 10, 83-98.

Gregorczyk, D. (2011). Emigracja polska w Bośni na przełomie XIX i XX wieku - problemy w sferze językowej i oświatowej. In R. Jankowska \& B. Nowosad (Eds.), Polityki językowe: wielojęzyczność i wielojęzykowość w Europie (pp. 113-130). Katowice: Rada Samorządu Studenckiego Międzynarodowej Szkoły Nauk Politycznych Uniwersytetu Śląskiego.

Gregorczyk, D. (2012). Aspekty polityczne i militarne udziału Polaków w działaniach zbrojnych na obszarze Bośni i Hercegowiny od II połowy XIX wieku do czasów współczesnych. In A. Barcik, R. Jankowska \& G. Libor (Eds.), Europejska Polityka Sąsiedztwa w regionie śródziemnomorskim (pp.63-85). Bielsko-Biała: Wydawnictwo Naukowe Akademii Techniczno-Humanistycznej.

Grela, J. (1996). Krytyka idei neoslawizmu na łamach petersburskiego czasopisma "Votum separatum" (rok 1908). Acta UAM, 1, 169-181.

Halili, R. (2002). Idea albańskiego odrodzenia narodowego i jego stosunek do Macedonii (1878-1912). In B. Zieliński (Ed.), Wokół Macedonii: siła kultury - kultura sity (pp. 189-206). Poznań: Wydawnictwo Naukowe Uniwersytetu im. Adama Mickiewicza.

Hedba, W. (2012). Kształtowanie się państwowości Czarnogóry. Politeja, 1, 359-388.

Jagiełło-Szostak, A. (2015). Społeczno-polityczne aspekty tożsamości narodowej Boszniaków z Sandżaku. Wschodnioznawstwo, 2005, 305-319.

Jakóbiec-Semkowowa, M. (2016a). Bałkański tygiel kultur i konfesji w dziewiętnastowiecznych relacjach polskich podróżników. Slavica Wratislaviensia, 162, 7-23.

Jakóbiec-Semkowowa, M. (2016b). Bałkański tygiel kultur i konfesji z polskiej perspektywy widziany (XIX-XXI wiek). In E. Dobierzewska-Mozrzymas \& A. Jezierski (Eds.), Nauka w służbie człowiekowi (pp. 143-150). Wrocław: ATUT.

Janusz, J. (2017). Galicja, Bośnia i Hercegowina: wspomnienia. Brzezia Łąka: Wydawnictwo Poligraf.

Kale, S. (2014). Chorwackie echa walki Polaków o wolność. Powstanie styczniowe w chorwackiej opinii publicznej. Studia z Dziejów Rosji i Europy Środkowo-Wschodniej, 69(1), 29-41.

Kale, S., \& Brlić, I. (2017). Podróż Bronisława Grabowskiego do Chorwacji i Slawonii w 1882 roku w świetle korespondencji administracji chorwackiej. In J. Pezda \& S. Pijaj (Eds.), Europa Środkowa Bałkany i Polacy. Studia ofiarowane profesorowi Antoniemu Cetnarowiczowi (pp. 395-406). Kraków: Historia Iagellonica.

Kaniecka, D. (2014). Opowiedzieć naród. Chorwackość według Augusta Šenoi. Kraków: Wydawnictwo Uniwersytetu Jagiellońskiego.

Karolczak, K. (2017). W oczach polskich arystokratów... Opatija w końcu XIX wieku. In J. Pezda \& S. Pijaj (Eds.), Europa Środkowa Bałkany i Polacy. Studia ofiarowane profesorowi Antoniemu Cetnarowiczowi (pp. 441-445). Kraków: Historia Iagellonica.

Kawka, M., \& Płaneta, P. (2013). Dyskursy o Macedonii. Kraków: Wydawnictwo UJ. 
Kawka, M., \& Stawowy-Kawka, I. (Eds.). (2008). Tożsamość narodowa w społeczeństwie multietnicznym Macedonii: historia, kultura, literatura, język, media. Kraków: Wydawnictwo Uniwersytetu Jagiellońskiego.

Kilias, J. (2000). Miroslava Hrocha dociekania i dyskusje dotyczące genezy nowoczesnych narodów. Przeglad Historyczny, 1, 109-129.

Klejn, Z. (2005). Walka o wolność Macedonii a Polacy. In I. Stawowy-Kawka (Ed.), Miejsce Macedonii na Bałkanach: historia, polityka, kultura, nauka (pp. 279-282). Kraków: Wydawnictwo Uniwersytetu Jagiellońskiego.

Kobylińska, A., Falski, M., \& Filipowicz, M. (2016a). Obcy czy obywatele? Słowianie a przemiany konstytucyjne w monarchii habsburskiej w latach 1860-1861. Kraków: Libron.

Kobylińska, A., Falski, M., \& Filipowicz, M. (2016b). Peryferyjność. Habsbursko-słowiańska historia nieoczywista. Kraków: Libron.

Koch, M. (2011). Ikony serbskiego romantyzmu jako bohaterowie współczesnej literatury popularnej. Polskie Studia Slawistyczne, 1, 127-144.

Kornhauser, J. (Ed.) (1999). Przemiany w świadomości i kulturze duchowej narodów Jugosławii po 1991 roku. Kraków: Wydawnictwo Uniwersytetu Jagiellońskiego.

Krajewska [z Kosmowskich], T. (1989). Pamiętnik (B. Czajecka, Ed.). Kraków: Wydawnictwo Uniwersytetu Jagiellońskiego.

Kryzia, W. (2008a). Problemy narodowościowe i językowe we wspomnieniach Josipa Vošnjaka. Południowosłowiańskie Zeszyty Naukowe, 5, 7-17.

Kryzia, W. (2008b). Słoweński, Słoweńcy i Słowenia. Zarys historii języka i kształtowania się świadomości narodowej. Kraków: Wydawnictwo Uniwersytetu Śląskiego.

Kubik, D. (2012). Słowiańszczyzna wyobrażona. Próba opisu XIX-wiecznego dyskursu slawistycznego. Pamiętnik Słowiański, 42(1-2), 5-24.

Kubik, D. (2015). Południowosłowiańska “kultura wyobrażona”. Projekt Mickiewiczowski a dziewiętnastowieczne dyskursy kulturowe w Serbii i Chorwacji. Kraków: Nomos.

Kubik, D. (2017a). Kształtowanie się idei narodu na ziemiach słoweńskich - zarys wybranych problemów. Slavia Meridionalis, 17, 1-19. DOI: https://doi.org/10.11649/sm.1340

Kubik, D. (2017b). Serbskie dziedzictwo Dubrownika w pismach Serbów dubrownickich i dalmatyńskich w XIX wieku. In D. Gil \& C. Juda (Eds.), Monologi, dialogi, polilogi w dyskursach kulturowych Słowiańszczyzny (pp. 187-204). Kraków: Scriptum.

Kwaśniak, F., \& Orlovac, A. (2013). Dzieje Polaków w Bośni 1895-1946 (J. Staszkowian, Trans.). Legnica: Biblioteka im. Jana Pawła II Wyższego Seminarium Duchownego Diecezji Legnickiej.

Lis, T. J. (2012). Wybrane przykłady lekarzy pracujących w Bośni i Hercegowinie na przełomie XIX i XX w. Archiwum Historii i Filozofii Medycyny, 75(2), 15-22.

Lis, T. J. (2013). Polityczne przyczyny kolonizacji polskiej w Bośni na przełomie XIX i XX wieku. Pamiętnik Słowiański, 63 (1/2), 151-164.

Lis, T. J. (2014a). Polskie osadnictwo i duchowieństwo w Bośni i Hercegowinie od 1894 do 1920 roku. Toruń-Nowa Ruda: Wydawnictwo Maria.

Lis, T. J. (2014b). Wkład Polaków w modernizację Bośni i Hercegowiny w okresie austro-węgierskim (1878-1918). Studia Migracyjne - Przeglad Polonijny, 40(4), 109-124. 
Lis, T. J. (2015a). Osadnictwo Rusinów w Bośni i Hercegowinie na przełomie XIX i XX wieku. Studia z Dziejów Rosji i Europy Środkowo-Wschodniej, 50(1), 25-41.

Lis, T. J. (2015b). Źródła epistolarne do dziejów misji sióstr felicjanek w Bośni i Hercegowinie w latach 1903-1904. Perspectiva, 14(1), 201-214.

Lis, T. J. (2015c). Źródła narracyjne do dziejów Polonii w Bośni i Hercegowinie w okresie austro-węgierskim. Balcanica Posnaniensia. Acta et studia, 22(2), 75-89.

Lis, T. J. (2016). Iz Bosni u Poljsku. Prikaz izvornih dokumenata na temu reemigracije Poljaka iz Bosne i Hercegovine nakon II svijetskog rata. Bolesławiec: Bolesławiecki Ośrodek Kultury - Międzynarodowe Centrum Ceramiki.

Lis, T. J., \& Maleszka, M. (Eds.). (2015). Poljska u Bosni. Bosna u Poljskoj. Kraków-Toruń-Sarajewo: Libron.

Majewski, P. (2013). (Re)konstrukcje narodu: odwieczna Macedonia powstaje w XXI wieku. Gdańsk: Wydawnictwo Naukowe Katedra.

Majewski, P. (2015). Kruševo: pomiędzy świętym miastem macedońskiego nacjonalizmu a pierwszym "etnomiastem" w Europie. $L u d$, 99, 161-184.

Makowski, K. (2013). Polskie badania nad dziejami Słowiańszczyzny - wprowadzenie do problemu. In K. Makowski \& M. Saczyńska (Eds.), Słowianie - idea i rzeczywistość. Zbiór studiów (pp. 7-18). Poznań: IH UAM.

Maleszka, M. (2015). Procesy akulturacji galicyjskich Żydów w Bośni: analiza teczek urzędniczych. Balcanica Posnaniensia. Acta et studia, 22(2), 91-100.

Malinowski, A. (2006). Kwestia macedońska w Bułgarii w latach 1878-1918. Toruń: Mado.

Malinowski, A. (2012a). Osmański system miletów a religijny nacjonalizm na przykładzie Kosowa. Gentes \& Nationes, 5, 69-81.

Malinowski, A. (2012b). Prasa włoska o powstaniu w Macedonii w 1903 roku. Słupskie Studia Historyczne, 18, 163-175.

Malinowski, A. (2014). Europejskie posiadłości Turcji w polityce Wielkiej Brytanii (1903-1914). Słupsk: Wydawnictwo Naukowe Akademii Pomorskiej.

Mandziuk, J. (2009). Polacy w Bośni i Hercegowinie 1878-1914. In J. Dzięgielewski (Ed.), Veritati-serviens. Księga pamiątkowa ojcu profesorowi Januszowi Zbudniewkowi zp. (pp. 667-681). Warszawa: Wydawnictwo UKSW.

Mikołajczak, A., Szulc, W., \& Zieliński B. (Eds.). (2004). Idee wspólnotowe Słowiańszczyzny południowej. Poznań: Wydawnictwo Naukowe UAM.

Miodońska, L. (2007). Macedonia - jej historia i język w najnowszych polskich publikacjach. Swiat i Słowo, 1, 307-319.

Miodyński, L. (2002). Granice kompetencji i granice tolerancji w badaniach macedonistycznych. In B. Zieliński (Ed.), Wokół Macedonii: siła kultury - kultura siły (pp. 75-89). Poznań: Wydawnictwo Naukowe Uniwersytetu im. Adama Mickiewicza.

Miodyński, L. (2011). Symbole miejsca w kulturze i literaturze macedońskiej. Katowice: Wydawnictwo Uniwersytetu Śląskiego.

Moroz-Grzelak, L. (2004). Aleksander Wielki a macedońska idea narodowa: słowiańskie losy postaci antycznej. Warszawa: Towarzystwo Naukowe Warszawskie, Instytut Slawistyki PAN. 
Moroz-Grzelak, L. (2006). Autorytet poprzedników a tworzenie własnej tradycji w opisaniu macedońsko-słowiańskich dziejów według G. M. Pulevskiego. In B. Zieliński (Ed.), Dalecy i bliscy: materiały VII Kolokwium Polsko-Macedońskiego (pp. 163-171). Poznań: Wydawnictwo Naukowe UAM.

Moroz-Grzelak, L. (2011). Bracia Słowianie. Wizje wspólnoty a rzeczywistość. Warszawa: Slawistyczny Ośrodek Wydawniczy.

Moroz-Grzelak, L. (2015). Kręgi zainteresowań problematyką macedońską w Polsce. Publikacje naukowe. Studia z Dziejów Rosji i Europy Środkowo-Wschodniej, 50(2), 145-156.

Moroz-Grzelak, L. (2018). Słowiańszczyzna i Zachód Europy w dyskusjach intelektualistów południowosłowiańskich przełomu wieków XIX i XX: pomiędzy dialogiem a negacją. In B. Zieliński (Ed.), Literaturoznawstwo, kulturoznawstwo, folklorystyka: prace na XVI Międzynarodowy Kongres Slawistów w Belgradzie 2018 (pp. 177-186). Poznań: Wydawnictwo Naukowe UAM.

Muś, J. (2013). Bośnia i Hercegowina: etnopolityczne podziały i ich uwarunkowania. Lublin: Wydawnictwo KUL.

Nikolaos, M. (1993). Fałszowanie historii Macedonii: hebrajskie źródła i świadectwa o Macedonii (W. Gawłowska \& I. Szelągiewicz, Trans.). Łódź: Wydawnictwo Uniwersytetu Łódzkiego.

Nowak-Bajcar, S. (1999). Kosowo - mit i historia w konflikcie serbsko-albańskim (szkic). In E. Szczęśniak-Kajzar (Ed.), Przemiany w świadomości i kulturze duchowej narodów Jugosławii po 1991 roku (pp. 87-102). Kraków: Wydawnictwo Uniwersytetu Jagiellońskiego.

Nowak-Bajcar, S. (2010). Belgrad Simy Matavulja: przyczynek do badań nad serbskim modernizmem przełomu XIX i XX wieku. Pamiętnik Słowiański, 60(2), 83-98.

Nowak-Bajcar, S. (2012a). Sarajevo - Zagrzeb - Kraków. O miejscach opuszczonych, odrzuconych i odnalezionych na austro-węgierskiej mapie biografii Ivo Andricia. Porównania, 11(1), 193-203.

Nowak-Bajcar, S. (2012b). Mapa pamięci. Serbska proza w poszukiwaniu pamięci kulturowej. In B. Zieliński (Ed.), Topografia tożsamości (Vol. 1, pp. 163-171), Poznań: Wydawnictwo Naukowe UAM.

Nowak-Bajcar, S. (2017). Geopolityka XIX-wiecznej podróży z geopoetyką w tle: przypadek Vuka Karadžicia i Petra Preradovicia. In D. Gil \& C. Juda (Eds.), Monologi, dialogi, polilogi $w$ dyskursach kulturowych Słowiańszczyzny (pp. 205-225). Kraków: Scriptum.

Nowak-Bajcar, S. (2018a). Srpsko-poljske naučne veze u svetlu prepiske Vuka Karadžića. In B. Zieliński (Ed.), Literaturoznawstwo, kulturoznawstwo, folklorystyka: prace na XVI Międzynarodowy Kongres Slawistów w Belgradzie 2018 (pp. 205-214). Poznań: Wydawnictwo Naukowe UAM.

Nowak-Bajcar, S. (2018b). Uloga Jagielonskog sveučilišta u oblikovanju vizje poljsko-hrvatskih odnosa u svjetlu utjecaja ideja Mariana Zdziechowskiego na njegove hrvatske studente na početku XX. stoljeća. In M. Czerwiński \& D. Agičić (Eds.), Polsko-hrvatske veze kroz stoljeća. Povijest, kultura, književnost (pp. 83-92). Zagreb: Srednja Europa.

Olszewski, P. (2010). Macedonia: historia i współczesność. Radom: WSH.

Paszkiewicz, J. (2005). Włoskie interesy ekonomiczne i polityczne na ziemiach macedońskich na przełomie XIX i XX wieku. In I. Stawowy-Kawka (Ed.), Miejsce Macedonii na Bałkanach: historia, polityka, kultura, nauka (pp. 233-240). Kraków: Wydawnictwo Uniwersytetu Jagiellońskiego. 
Pielech, K. (2008). Emigracja i życie Polaków w Bośni w latach 1890-1946. Boleslawiec: Proart Visual Art \& Design Studio.

Pieniążek-Marković, K. (2014). Bośnia - hortus horridus: obraz Bośni w podróżach franciszkanów Grgi Marticia i Ivana Frano Jukicia. Prace Filologiczne. Literaturoznawstwo, 4, 263-278.

Pieniążek-Marković, K. (2016). Od marzeń o wyzwoleniu po tęsknotę za utraconą arkadią: dziewiętnastowieczne relacje z podróży bośniackich franciszkanów. In J. Dziuba, M. Gustin, N. Wyszogrodzka-Liberadzka \& R. Wyżkiewicz-Maksimow (Eds.), Słowianie w podróży (Vol. 1. Język i kultura, pp. 27-40). Gdańsk: Wydawnictwo Uniwersytetu Gdańskiego.

Pijaj, S. (1992). Wpływ ugody węgiersko-chorwackiej 1868 roku na formułowanie postulatów rezolucji sejmu galicyjskiego z 24 września 1868 roku. Rocznik Naukowo-Dydaktyczny WSP $w$ Krakowie, 126, 79-102.

Pijaj, S. (2017). Rodzina Hristić i jej związki z Polską. In J. Pezda \& S. Pijaj (Eds.), Europa Środkowa Bałkany i Polacy. Studia ofiarowane profesorowi Antoniemu Cetnarowiczowi (pp. 293-308). Kraków: Historia Iagellonica.

Podhorodecki, L. (2000). Jugosławia: dzieje narodów, państw i rozpad federacji. Warszawa: MADA.

Potkański, W. (2011). Spór o niezależność Macedonii we współczesnej “zjednoczonej” Europie, Part 1: Okres do wybuchu II wojny światowej. Zeszyty Naukowe - Uniwersytet Szczeciński. Acta Politica, 24, 51-61.

Pudłocki, T. (2016). Franciszek Tomaszewski i njegovo putovanje po hrvatskim krajevima. Historijski zbornik, 69(2), 385-410.

Rapacka, J. (1992a). Uwagi o kształtowaniu się antyokcydentalizmu serbskiego. In T. Dąbek-Wigrowa \& A. Makowiecki (Eds.), Kategorie Europy w kulturach słowiańskich (pp. 125-132). Warszawa: Uniwersytet Warszawski, Wydział Polonistyki.

Rapacka, J. (1992b). Z dziejów mitu kosowskiego. Od Miloša Obilicia do Gavrilo Princpa. Pamiętnik Słowiański, 42, 3-14.

Rapacka, J. (1993). Rola regionalizmu w kulturze chorwackiej. In K. Handke (Ed.), Region, regionalizm - pojęcia i rzeczywistość (pp. 195-208). Warszawa: Slawistyczny Ośrodek Wydawniczy.

Rapacka, J. (1995). Godzina Herdera. O Serbach, Chorwatach i idei jugosłowiańskiej. Warszawa: Energeia.

Rapacka, J. (1996). Schyłek ideologii szlacheckich w obliczu kształtowania się ideologii narodowych w krajach Korony św. Stefana (na przykładzie chorwackim). In M. Bobrownicka (Ed.), Symbioza kultur słowiańskich i niesłowiańskich w Europie Środkowej (pp. 81-88). Kraków: Universitas.

Rapacka, J. (1997). Leksykon tradycji chorwackich. Warszawa: Slawistyczny Ośrodek Wydawniczy PAN.

Rapacka, J. (2001). X. Adam Sapieha, czyli podróż przez Chorwację polskiego słowianofila. Pamiętnik Słowiański, 51, 65-73.

Rapacka, J. (2002). Śródziemnomorze - Europa - Bałkany. Studia o literaturze południowosłowiańskiej. Kraków: Universitas.

Rapacka, J. (2003). Rzeczypospolita Dubrownicka. Sejny: Fundacja Pogranicze. 
Rapacka, J. (2004). Adam Mickiewicz a romantyzm chorwacki. Pamiętnik Słowiański, 54(1), 3-11. Rubacha, J. (2004). Bułgarski sen o Bizancjum. Polityka Bułgarii w latach 1878-1913. Warszawa: Neriton.

Rubacha, J. (2012). Bułgaria na przełomie XIX i XX wieku. Bułgarskie metamorfozy w publikacjach "Świata Słowiańskiego" (1905-1914). Olsztyn: Wydawnictwo UWM.

Rubacha, J., \& Malinowski, A. (Eds.). (2007). Historia Bułgarii 1870-1915: materiały źródłowe $z$ komentarzami. T. 2: Kwestia macedońska. Warszawa: Neriton.

Rycerska, I. (2003). Rozpad Jugosławii: przyczyny i przebieg. Kielce: Akademia Świętokrzyska.

Seroka, M. (2011). Najszlachetniejszej krwi Chorwaci: Ante Starčević i Bośnia. Pamiętnik Słowiański, 61(1), 107-121.

Seroka, M. (2013). Chorwacja turecka - Turcja europejska? Bośnia w podróżopisarstwie epoki jugoslawizmu. Pamiętnik Słowiański, 63 (1/2), 89-113.

Skorczewski, M. (2013). Kosowo, mit kosowski i jego recepcja. Studia z Dziejów Rosji i Europy Środkowo-Wschodniej, 48, 283-292.

Skowronek, J. (1990). Kraje bałkańskie a powstanie styczniowe. In S. Kalembka (Ed.), Powstanie styczniowe 1863, Wrzenie-bój, Europa, wizje (pp. 611-636). Warszawa: PWN.

Skowronek, J. (1991). Panslavisme, slavophilie et re construction politique de l'Europe Centrale Au XIX-éme siècle. In G. Beauprêtre (Ed.), L’Europe Centrale-realité, mythé enjeu XVIII-XX siècle (pp. 317-328). Varsovie: Editions de L'Université de Varsovie.

Skowronek, J. (1991). Polacy wobec bałkańskich ruchów narodowych. In W. Balcerak (Ed.), Polska-Bułgaria przez wieki XVII-XX: materiały z sesji Komisji Historycznej Polsko-Butgarskiej (pp. 31-39). Warszawa: Instytut Historii PAN.

Skowronek, J. (1996). Panslawizm i wizje słowiańskie w warunkach tworzonych przez rozbiory Polski. Przegląd Humanistyczny, 40(1), 193-198.

Skowronek, J. (1997). Europa Środkowo-Wschodnia w projekcie i działalności ks. Adama J. Czartoryskiego (1803-1861). In A. Cetnarowicz, C. Gy. Kiss \& I. Kovacs (Eds.), Wegry Polska w Europie Środkowej. Historia-Literatura. Księga pamiątkowa ku czci Profesora Wacława Felczaka (pp. 105-118). Kraków: Wydawnictwo Profesjonalnej Szkoły Biznesu.

Skowronek, M., Tanty, T. \& Wasilewski, T. (1977). Historia Słowian Zachodnich i Południowych. Warszawa: PWN.

Stankowicz, A. (1996). Rola Austrii w kształtowaniu kultury i życia literackiego w Bośni i Hercegowinie. In M. Bobrownicka (Ed.), Symbioza kultur słowiańskich i niesłowiańskich $w$ Europie Środkowej (pp. 123-128). Kraków: Universitas.

Stankowicz, A. (1997). Bośniacka świadomość historyczna w polityce narodowościowej Austrii. In M. Bobrownicka, L. Suchanek \& F. Ziejka (Eds.), Współcześni Słowianie wobec własnych tradycji i mitów. Sympozjum w Castel Gandolfo w dniach 19-20 maja 1996 (pp. 87-94). Kraków: Universitas.

Stankowicz, A. (2003). Jedność wielokulturowej Bośni i Hercegowiny. Prace Komisji Środkowoeuropejskiej PAU, 11, 35-47.

Stankowicz, A. (2004). Między bośniackością a jugoslawizmem: z dziejów kultury bośniackiej. Bielsko-Biała: Wydawnictwo AT-H.

Stawowy-Kawka, I. (2000). Historia Macedonii. Wrocław: Zakład Narodowy im. Ossolińskich. 
Stawowy-Kawka, I. (2002). Kosowo - problemy narodowe. Prace Komisji Środkowoeuropejskiej, 10, 39-57.

Stawowy-Kawka, I. (2014). Albańczycy w Macedonii 1944-2001. Kraków: Wydawnictwo UJ.

Stawowy-Kawka, I. (Ed.). (2005). Miejsce Macedonii na Bałkanach: historia, polityka, kultura, nauka. Kraków: Wydawnictwo Uniwersytetu Jagiellońskiego.

Stawowy-Kawka, I. (Ed.). (2007). Obraz konfliktów między narodami słowiańskimi w XIX i XX wieku w historiografii. Kraków: Wydawnictwo UJ.

Stępnik, K. (2014). Macedonia w prasie polskiej (1903-1914). Lublin: Wydawnictwo UMCS.

Stępnik, K., \& Gabryś, M. (Eds.). (2010). Południowa Słowiańszczyzna w literaturze polskiej XIX $i$ XX wieku. Lublin: Wydawnictwo UMCS.

Szczepański, W. (2006). Serbowie a Albańczycy w latach 1878-1918. Dzieje Najnowsze, 38(1), 195-200.

Szczepański, W. (2007). Mity i stereotypy: stosunek elit serbskich do Albańczyków z wilajetu kosowskiego (1878-1912). Przeglad Zachodni, 63(3), 143-156.

Szczepański, W. (2009). Ponad granicami, podziałami i uprzedzeniami: Dimitrijr Tucović o Albańczykach, relacjach serbsko-albańskich i Kosowie. Balcanica Posnaniensia. Acta et studia, 15, 189-206.

Szczepański, W. (2010). Kosowo (zarys historii polityczno-społecznej). Przegląd Zachodni, 66(1), 115-139.

Szczepański, W. (2013). Cele polityczne i terytorialne Królestwa Czarnogóry w przededniu i w trakcie I wojny bałkańskiej. Balcanica Posnaniensia. Acta et studia, 20, 117-136.

Świątek, A. (2017). "Gazeta Narodowa” wobec powstania w Boce Kotorskiej w 1869 roku. In J. Pezda \& S. Pijaj (Eds.), Europa Środkowa Bałkany i Polacy. Studia ofiarowane profesorowi Antoniemu Cetnarowiczowi (pp. 383-394). Kraków: Historia Iagellonica.

Tokarz, E. (1994). Poljska slovenistika v okviru poljsko-slovenskih stikov. Slavistična revija, 42(2/3), 393-398.

Viazemskaia, E. K. (2011). Vliianie migratsii na territorii Bosnii i Gertsegoviny na polozhenie mestnykh ètnicheskikh grupp naseleniia v nachale XX veka. In T. A. Pokivaĭlova (Ed.), Migratsiia i emigratsiia v stranakh TSentral'noй i IUgo-vostochnoй Evropy v XVIII-XX vv.: sokhranenie natsional'noŭ identichnosti i istoriko-kul'turnogo naslediis Rossii (pp. 162-202). Sankt-Peterburg: Aleteriia.

Waldenberg, M. (2000). Jugosławia: byt wspólny i rozpad. Warszawa: Trio.

Waldenberg, M. (2005). Rozbicie Jugosławii. Od separacji Słowenii do wojny kosowskiej. Warszawa: Scholar.

Wereszycki, H. (2015). Pod berłem Habsburgów. Zagadnienia narodowościowe. Kraków: Wydawnictwo Literackie.

Wichniewicz, P. (2015). Zapomniani koloniści w północnej Bośni. In R. Sendek, K. Popek \& M. Maszkiewicz (Eds.), Przestrzenie, których już nie ma: pamięć w południowej i zachodniej Słowiańszczyźnie (pp. 167-180). Kraków: Scriptum.

Wichniewicz, P. (2017). Powroty: polska mniejszość narodowa w Ćelinovacu, Bośnia i Hercegovina. In M. Lachowicz \& K. Polasik-Wrzosek (Eds.), Język polski jako nośnik tożsamości (pp. 107-120). Poznań: Instytut Wschodni UAM. 
Wołek, K. (2004). Między Orientem a swojszczyzną - obraz Dalmacji w XIX-wiecznym podróżopisarstwie polskim. Pamiętnik Słowiański, 54, 29-50.

Wrocławski, K., Bogusławska M., \& Różycki, N. (Eds.). (2003). Polacy w Bośni, Polacy o Bośni: przewodnik bibliograficzny z komentarzami. Warszawa: Uniwersytet Warszawski. Instytut Slawistyki Zachodniej i Południowej.

Wrocławski, K., \& Bogusławska, M. (2007). Polska i Czarnogóra: bibliografia, komentarze. Warszawa: Instytut Slawistyki Zachodniej i Południowej UW.

Wrocławski, K., Bogusławska, M., \& Wróblewska-Trochimiuk, E. (2009). Polska i Macedonia: bibliografia, komentarze, studia. Warszawa: Instytut Slawistyki Zachodniej i Południowej Uniwersytetu Warszawskiego.

Zalewski, K. M. (2010). Naród, religia, rasa: muzułmańskie ideologie i ruchy narodowe pogranicza $w$ Południowo-Wschodniej Europie: przykład Sandżaka nowopazarskiego w XX wieku. Warszawa: Wydawnictwo Trio.

Zieliński, B. (1998). Serbska powieść historyczna. Studia na źródłami, ideami i kierunkami rozwoju. Poznań: Wydawnictwo Naukowe UAM.

Zieliński, B. (2002a). Narodowy i ponadnarodowy model kultury w Europie Środkowej. Pamiętnik Słowiański, 52, 99-102.

Zieliński, B. (Ed.). (2002b). Narodowy i ponadnarodowy model kultury. Europa Środkowa i Półwysep Bałkański. Poznań: Wydawnictwo Naukowe UAM.

Zieliński, B. (2009). Stereotypizacja Słowiańszczyzny południowej w polskim dyskursie publicznym III Rzeczypospolitej (po roku 1989). Południowosłowiańskie Zeszyty Naukowe, 6, 11-23.

Zieliński, B. (2012). Topografia tożsamości (Vol. 1). Poznań: Wydawnictwo Naukowe UAM.

Znamierowska-Rakk, E. (2000). Z dziejów bałkańskich koncepcji federacyjnych (od schyłku XVIII w. do końca I wojny światowej). Studia z Dziejów Rosji i Europy Środkowo-Wschodniej, 35, 5-23.

Żurek, P. (2003). Relacje kardynała Mieczysława Ledóchowskiego z Kościołem katolickim w Serbii w II połowie XIX wieku. Przegląd Historyczny, 94(1), 23-41.

Żurek, P. (2004). Nowa interpretacja genezy "Načertanija" - serbocentryzm Hotelu Lambert a Chorwaci. In A. W. Mikołajczak, W. Szulc \& B. Zieliński (Eds.), Idee wspólnotowe Słowiańszczyzny południowej (pp. 109-120). Poznań: Wydawnictwo Naukowe UAM.

Żurek, P. (2005a). Akcja Hotelu Lambert na rzecz obalenia bana Chorwacji Josipa Jelačicia w dobie Wiosny Ludów. Przegląd Historyczny, 96(3), 434-448.

Żurek, P. (2005b). Hotel Lambert i Chorwaci (1848-1850). Warszawa: Bellona.

Żurek, P. (2005c). Tajne porozumienie Hotelu Lambert z Chorwacką Partią Narodową w świetle raportów Franciszka Zacha (1844). Prace Komisji Środkowoeuropejskiej PAU, 13, 141-148.

Żurek, P. (2006). Polska i Polacy w życiu Josipa Juraja Strossmayera. Bielsko-Biała: Wydawnictwo Akademii Techniczno-Humanistycznej.

Żurek, P. (2007a). Chorwacja i Chorwaci w tradycji rodu Sapiehów. In K. Stępnik (Ed.), Sapiehowie epoki Kodynia i Krasiczyna (pp. 517-525). Lublin: Wydawnictwo Uniwersytetu Marii Curie-Skłodowskiej.

Żurek, P. (2007b). Geneza idei jugosłowiańskiej jako problem historyczny. In I. Stawowy-Kawka (Ed.), Obraz konfliktów między narodami słowiańskimi w XIX i XX wieku w historiografii (pp. 111-116). Kraków: Wydawnictwo UJ. 
Żurek, P. (2007c). Strossmayer i Poljaci. In M. Dąbrowska-Partyka \& M. Czerwiński (Eds.), Josip Juraj Strossmayer. Hrvatska, ekumenizam, Europa / Chorwacja, ekumenizm, Europa (pp. 309-321). Kraków: Scriptum.

Żurek, P. (2008). Poljska i Poljaci u životu Josipa Juraja Strossmayera. Slavonski Brod: Hrvatski institut za povijest - Podružnica za povijest Slavonije, Srijema i Baranje.

Żurek, P. (2012a). Andrija Torkvat Brlić i Hotel Lambert. In Zbornik o Andriji Torkvatu Briću (D. Župan, Ed.) (pp. 155-168). Slavonski Brod: Hrvatski institut za povijest - Podružnica za povijest Slavonije, Srijema i Baranje.

Żurek, P. (2012b). Narodowość czarnogórska w dualizmie tożsamości przed II wojną światową i po niej. In M. Fic \& R. Kaczmarek (Eds.), Wieki stare i nowe, Special Volume: Ludzie i elity pogranicza (pp. 246-256). Katowice: Uniwersytet Śląski.

Żurek, P. (2012c). Sječanski ustanak 1863 u Polskoj i Eugen Kvaternik. Slavonski Brod: Hrvatski institut za povijest - Podružnica za povijest Slavonije, Srijema i Baranje.

Żurek, P. (2013). Podwójne pogranicze. Rzecz o specyfice sąsiedztwa czarnogórsko-serbskiego. In R. Łoś \& J. Regina-Zacharski (Eds.), Sąsiedztwo i pogranicze. Między konfliktem a wspótpraca (Vol. 2, pp. 59-65). Łódź: Wydawnictwo Uniwersytetu Łódzkiego.

Żurek, P. (2015). Pokušaji stvaranja agencije Hotela Lambert u Bosni. In T. J. Lis \& M. Maleszka (Eds.), Poljska u Bosni, Bosna u Poljskoj (pp. 13-31). Kraków-Toruń-Sarajevo: Libron.

Żurek, P. (2017). Miejsce Bośni w bałkańskiej polityce Hotelu Lambert (1843-1849). In J. Pezda \& S. Pijaj (Eds.), Europa Środkowa Bałkany i Polacy. Studia ofiarowane profesorowi Antoniemu Cetnarowiczowi (pp. 371-382). Kraków: Historia Iagellonica.

Żurek, P. (Ed.). (2007). Polska i Chorwacja w Europie Środkowej (integracja europejska $w$ tradycji i przeszłości). Bielsko-Biała: Wydział Humanistyczno-Społeczny ATH.

Żurek, P., \& Lupis, V. (2012). Poljski ustanak 1863 i Dubrovnik, Zagreb: Veleposlanstvo Republike Poljske.

\section{Polska humanistyka ostatniego ćwierćwiecza dotycząca historii narodów i krajów byłej Jugosławii, ich związków polityczno-kulturalnych z Polakami oraz idei wspólnotowych w drugiej połowie XIX wieku}

W niniejszym artykule zostanie przeprowadzony przegląd tematów badawczych dotyczących historii narodów oraz krajów, które po 1918 roku utworzyły państwo jugosłowiańskie, w drugiej połowie XIX, w polskiej humanistyce po 1989 roku. Jako orientacyjną cezurę czasową przyjęto lata 1848-1908.

Słowa kluczowe: polska historiografia, polska humanistyka, Słowiańszyczna Południowa, Jugosławia, relacje między Polakami a Słowianami Południowymi, druga połowa XIX wieku 


\section{The last twenty-five years of Polish humanities related to the history of the nations and countries of former Yugoslavia, their political and cultural relations with Poles and unionism ideas in the second half of the $19^{\text {th }}$ century}

This paper presents an overview of the research topics that have appeared in Polish humanities since 1989 concerning the second half of the $19^{\text {th }} \mathrm{c}$. history of the nations and countries which went on to create the Yugoslavian state after 1918. The period we chose is 1848 to 1908.

Keywords: Polish historiography, Polish humanities, South Slavs, Yugoslavia, relations between Poles and South Slavs, second half of $19^{\text {th }} \mathrm{c}$.

\section{Notka o autorach}

Antoni Cetnarowicz (antoni.cetnarowicz@uj.edu.pl) - em. profesor zwyczajny w Instytucie Historii Uniwersytetu Jagiellońskiego. Zainteresowania badawcze: dzieje Europy Środkowej i Bałkanów w XIX wieku ze szczególnym uwzględnieniem zagadnień narodowościowych w monarchii habsburskiej i związków Polaków ze Słowiańszczyzną południową. Autor monografii: Słoweński ruch narodowy i jego stosunek do spraw polskich (1848-1879), Kraków 1991; Tajna dyplomacja Adama J. Czartoryskiego na Bałkanach. Hôtel Lambert a kryzys serbski w latach 1840-1844, Kraków 1993 (przetłumaczonej na j. serbski); Odrodzenie narodowe w Dalmacji. Od „slavenstva” do nowoczesnej chorwackiej i serbskiej idei narodowej, Kraków 2001 (przetłumaczonej na j. niemiecki i chorwacki); Odrodzenie narodowe w Istrii w latach 1860-1907, Kraków 2010 (przetłumaczonej na j. chorwacki) oraz ponad 100 prac wydanych również w językach: niemieckim, chorwackim, słoweńskim, włoskim, angielskim.

Antoni Cetnarowicz (antoni.cetnarowicz@uj.edu.pl) - Professor Emeritus at the Institute of History of Jagiellonian University in Cracow. Research interests: the history of Central Europe and the Balkans in the nineteenth century; nationality issues in the Habsburg monarchy and the relations between Poles and Southern Slavs. Author of the books: Słoweński ruch narodowy i jego stosunek do spraw polskich (1848-1879) [Slovenian National Movement and 
its Relation to the Polish Questions (1848-1879)], Cracow 1991; Tajna dyplomacja Adama J. Czartoryskiego na Bałkanach. Hôtel Lambert a kryzys serbski w latach 1840-1844 [Secret Diplomacy of Adam J. Czartoryski in the Balkans. Hôtel Lambert and Serbian Crisis in 1840-1844], Cracow 1993 (translated into Serbian); Odrodzenie narodowe w Dalmacji. Od "slavenstva" do nowoczesnej chorwackiej i serbskiej idei narodowej [The National Revival in Dalmatia. From "slavenstvo" to the modern Croatian and Serbian National Idea], Cracow 2001 (translated into German and Croatian); Odrodzenie narodowe w Istrii w latach 1860-1907 [The National Revival in Istria in 1860-1907], Cracow 2010 (translated into Croatian), and around 100 other works in German, Croatian, Slovene, Italian, and English.

Krzysztof Popek (popek.kj@gmail.com) - doktorant na Wydziale Historycznym Uniwersytetu Jagiellońskiego. Autor monografii pt. „Turecka opończa, belgijska peleryna”. Obraz państwa bułgarskiego w twórczości satyrycznej przełomu XIX i XX wieku (Kraków 2016). Zainteresowania badawcze: dzieje polityczno-społeczne Półwyspu Bałkańskiego w XIX wieku ze szczególnym uwzględnieniem historii mniejszości oraz migracji w Bułgarii oraz Serbii. Publikował artykuły z zakresu historii Bałkanów na łamach m.in. „Slavonic Review” (Praga), „Studia z Dziejów Rosji i Europy Środkowo-Wschodniej” czy „Balcanica Posnaniensia. Acta et studia”.

Krzysztof Popek (popek.kj@gmail.com) - PhD Candidate at the Faculty of History of Jagiellonian University in Cracow. Research interests: political and social history of the Balkan Peninsula in the nineteenth century with particular reference to the history of minorities and migration in Bulgaria and Serbia. The author of the book "Turecka oponcza, belgijska peleryna". Obraz państwa bułgarskiego w twórczości satyrycznej przełomu XIX i XX wieku ["Turkish Mantle, Belgian Cloak". Image of the Bulgarian State in Satirical Works at the Turn of the 19th and 20th centuries], Cracow 2016 and articles published, e.g., in "Slavonic Review" (Prague), "Studia z Dziejów Rosji i Europy ŚrodkowoWschodniej” (Warsaw) or "Balcanica Posnaniensia. Acta et studia” (Poznań). 